\title{
Preliminary Failure Modes and Effects Analysis of the US Massive Gas Injection Disruption Mitigation System Design
}

Lee C. Cadwallader

October 2013

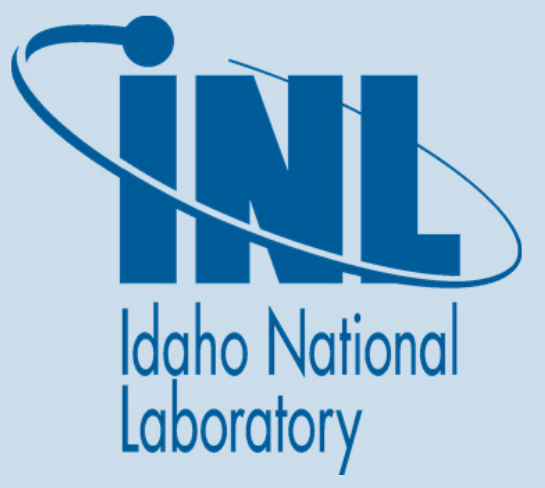

The INL is a U.S. Department of Energy National Laboratory operated by Battelle Energy Alliance 


\title{
Preliminary Failure Modes and Effects Analysis of the US Massive Gas Injection Disruption Mitigation System Design
}

\author{
Lee C. Cadwallader
}

October 2013

\begin{abstract}
Idaho National Laboratory Experimental Programs Department Idaho Falls, Idaho 83415
\end{abstract}

Prepared for the U.S. Department of Energy Office of Fusion Energy Sciences Under DOE Idaho Operations Office Contract DE-AC07-05ID14517 


\begin{abstract}
This report presents the results of a preliminary failure modes and effects analysis (FMEA) of a candidate design for the ITER Disruption Mitigation System. This candidate is the Massive Gas Injection System that provides machine protection in a plasma disruption event. The FMEA was quantified with "generic" component failure rate data as well as some data calculated from operating facilities, and the failure events were ranked for their criticality to system operation.
\end{abstract}





\section{CONTENTS}

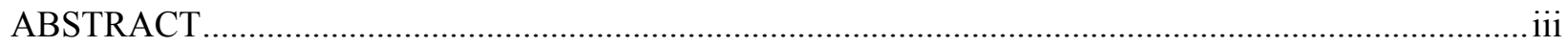

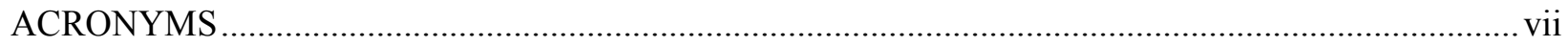

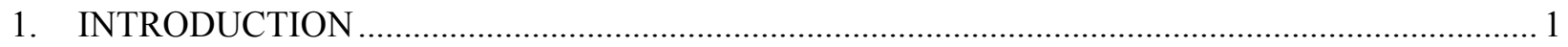

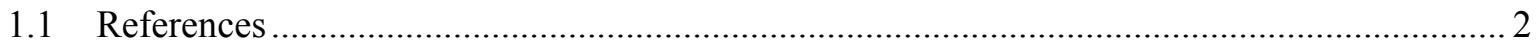

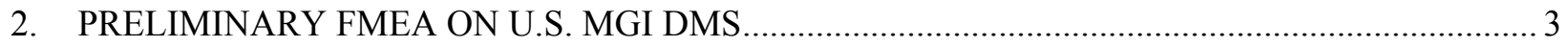

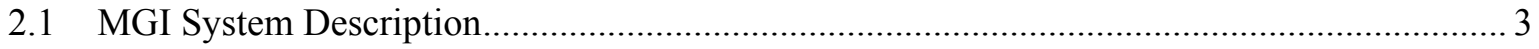

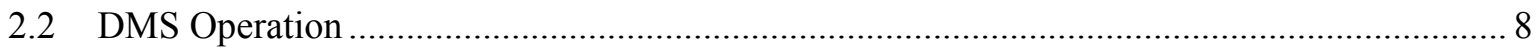

2.3 Related Operating Experiences Supporting the FMEA …................................................ 9

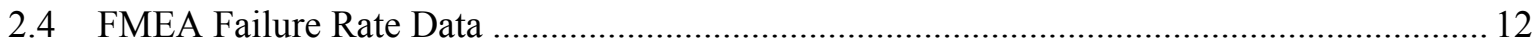

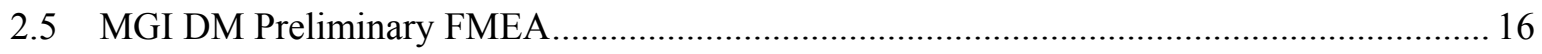

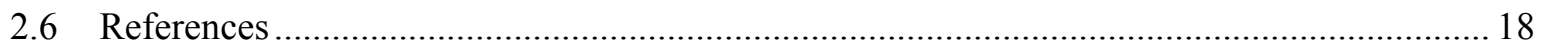

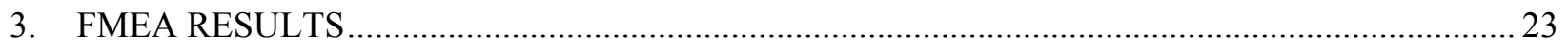

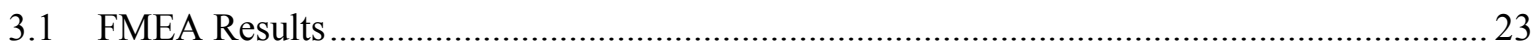

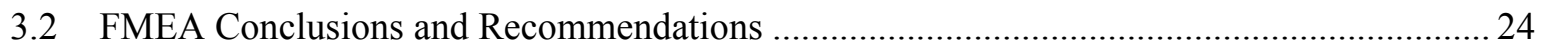

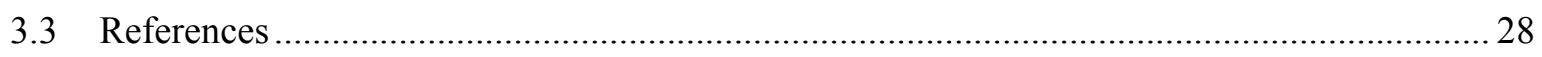

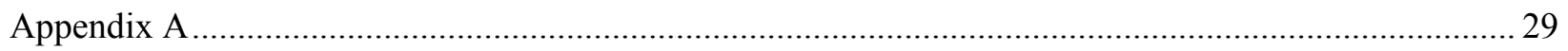

Preliminary Failure Modes and Effects Analysis for the MGI DM System ..........................................2 29 


\section{FIGURES}

Figure 2-1. Flow schematic diagram of a single thermal mitigation DMS valve (Baylor, 2012)............... 4

Figure 2-2. Location of a thermal mitigation DMS valve in an upper port plug (Baylor, 2012)............... 4

Figure 2-3. Sketch of the Fast Valve Triggering Electronic System (Baylor, 2012)............................... 5

Figure 2-4. MGI DM valve concept for ITER (Baylor, 2013) .......................................................... 5

\section{TABLES}

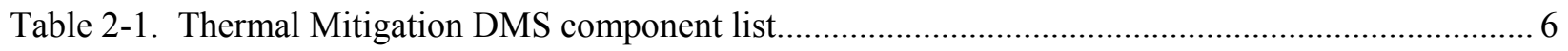

Table 2-2. Normal Environmental Conditions for DM System Areas................................................. 9

Table 2-3. DM valve operations experience from existing tokamaks.............................................. 10

Table 2-4. Some failure rate modifiers for radiation environments .................................................... 13

Table 2-5. Failure Mode Severity for System Outage. …................................................................ 17

Table 2-6. Failure Mode Occurrence Frequency. .......................................................................... 17

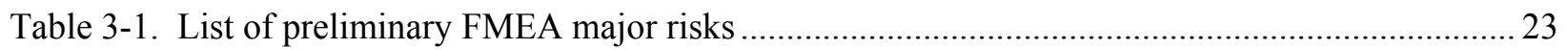

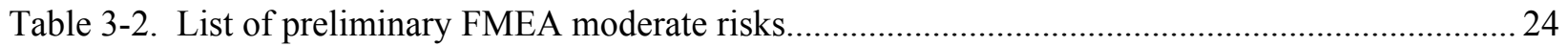




\section{ACRONYMS}

\begin{tabular}{ll} 
C & Criticality of failure \\
d & demands \\
D & Detection of failure \\
DM & disruption mitigation \\
DMS & Disruption Mitigation System \\
EM & electromagnetic \\
FMEA & failure modes and effects analysis \\
h & hours \\
ITER & The ITER International Project, ITER is Latin for "the way" \\
JET & Joint European Torus \\
LFL & lower flammable limit \\
MAST & Mega-Amp Spherical Torus \\
MFC & mass flow controller \\
MGI & massive gas injection \\
MTTR & mean time to repair \\
NDT & non-destructive test \\
O & Occurrence frequency of failure \\
PLC & programmable logic controller \\
QA & Quality Assurance \\
RED & Runaway electron dissipation \\
RES & Runaway electron suppression \\
RFX & Reversed Field Pinch Experiment \\
RPN & risk priority number \\
S & Severity of failure \\
TM & thermal mitigation \\
UFL & upper flammable limit \\
vppm & volume parts per million \\
y & year \\
\hline
\end{tabular}




\section{Preliminary Failure Modes and Effects Analysis of the US Massive Gas Injection Disruption Mitigation System Design}

\section{INTRODUCTION}

This report presents the results of a preliminary failure modes and effects analysis (FMEA) of a candidate system to provide plasma disruption mitigation for the ITER International Project. This candidate system is the massive gas injection system that injects a mixture of helium, neon, argon, and deuterium to protect the first wall and/or high heat flux components from damage in loss of plasma control events or from major disturbances in the plasma. The Central Interlock System triggers the Disruption Mitigation System (DMS) and it functions to terminate the plasma (SRD, 2013). Plasma disruption mitigation is mandatory for ITER to reduce halo current and eddy current forces on the vacuum vessel, mitigate heat loads and to avoid or mitigate runaway electrons (Lehnen, 2011). Using a gas mixture allows the advantages of past gas particle delivery rate with helium gas and the large radiation absorption capability of argon gas (Bakhtiari, 2011).

The FMEA is a fundamental type of reliability tool that is used to identify failures of individual system components in a systematic, thorough manner, quantify the failures, and identify possible corrective actions. In this case, the FMEA will also provide a focus on maintenance of the system. The FMEA can be used to determine the most hazardous failures of system components (which can be used in risk assessment) and the reliability of a system. Because the DMS designs have not been downselected to one primary design, the design information available to be used in this report is preliminary and the FMEA is also identified as preliminary.

The U.S. has developed two DMS designs: the massive gas injection system (MGI) discussed in this report, and a pellet injector that fires cryogenic pellet that will shatter and spread out into the plasma. The MGI system is described in a design document (DDD, 2012). The DMS pellet injector design will be addressed in another report.

The MGI DMS system boundaries are the pressure vessel penetration, the gas supply, the compressors and electrical power supply for line power and for instrument power. The MGI would reside mainly within the Diagnostics Port Plug. The system includes instrumentation for monitoring and control and their associated electronics cubicles.

This FMEA uses the hardware approach rather than the ITER functional approach. This approach is used since there are still two design options at present and the hardware approach is less complicated to pursue while evaluating the two designs.

The FMEA follows the format given in a recognized industrial standard, IEEE 352 (IEEE, 1991). There are other industrial standards (SAE, 2009; AIAG, 2008; IEC, 2006; MIL, 1984) but the nuclear standard was selected to provide the basic FMEA format for this task due to the MGI being less of a mass-produced item than those items that other standards were written to address (for example, the AIAG and SAE standards address automobile manufacturing) and since ITER is a nuclear tokamak with radioactive material inventories.

The FMEA addresses the MGI in its operating mode during a normal ITER pulse operation over an average year. The FMEA does not address system downtime between ITER campaigns. 


\subsection{References}

AIAG, 2008. Potential Failure Mode and Effects Analysis, $4^{\text {th }}$ edition, Automotive Industry Action Group, a consortium of DiamlerChrysler, Ford Motor Company, and General Motors Corporation, Southfield, Michigan, 2008.

Bakhtiari, 2011. M. Bakhtiari et al., "Using mixed gases for massive gas injection disruption mitigation on Alcator C-Mod," Nuclear Fusion, 51 (2011) doi: 10.1088/00295515/51/6/063007.

DDD, 2012. Conceptual Design Description Document for the DMS ORNL Massive Gas Injection System, ITER IDM DCQYNS, December 1, 2012.

IEC, 2006. Analysis techniques for system reliability-Procedure for failure mode and effects analysis, IEC 60812, second edition, International Electrotechnical Commission, Geneva, Switzerland, 2006.

IEEE, 1991. IEEE Guide for General Principles of Reliability Analysis of Nuclear Power Generating Station Safety Systems, IEEE Std 352-1987, reaffirmed 1991, Institute of Electrical and Electronics Engineers, New York, USA (1991).

Lehnen, 2011. M. Lehnen et al., "Disruption mitigation by massive gas injection in JET," Nuclear Fusion, 51 (2011) doi:10.1088/0029-5515/51/12/123010.

MIL, 1984. Procedures for Performing a Failure Mode Effects and Criticality Analysis, MIL STD 1629A, US Department of Defense, change notice 2, November 28, 1984. Note: this standard was cancelled on August 4, 1998 with no replacement. Despite cancellation, this standard remains an excellent guide for FMEA.

SAE, 2009. Potential Failure Mode and Effects Analysis in Design, Potential Failure Mode and Effects Analysis in Manufacturing and Assembly Processes, SAE J1739, Society of Automotive Engineers, Warrendale, Pennsylvania, USA, January 2009.

SRD, 2013. System Requirement Document, SRD-18-M, Disruption Mitigation System, ITER IDM number BEJQWA, version 1.4, May 3, 2013. 


\section{PRELIMINARY FMEA ON U.S. MGI DMS}

The FMEA for the massive gas injection system is given below. First the system is described, then the operating mode is described. The FMEA table pages are in an appendix; the results are summarized in the next chapter.

\subsection{MGI System Description}

This description was taken from the design description document (Baylor, 2012) and system requirements document (Maruyama, 2013). The massive gas injection system operates to protect ITER vacuum vessel internals from the effects of plasma disruption events. The electronics of the Central Interlock System send an actuation signal that triggers the DMS within $1 \mathrm{~ms}$ of sensing an abnormal plasma condition. The DMS has two goals, runaway electron suppression (RES) by gas from one port that must operate quickly and suppress within $500 \mathrm{~ms}$, and thermal load mitigation (TM) by gas from four ports that must operate quickly and mitigate within $20 \mathrm{~ms}$; the design requirement is that $90 \%$ of the valve reservoir inventory arrives at the plasma edge within $20 \mathrm{~ms}$ and at 1 bar pressure. The thermal load mitigation system shall only deliver a maximum of $10 \mathrm{kPa}-\mathrm{m}^{3}$ gas in one actuation. As stated, there are multiple MGI ports, $\mathrm{TM}$ and RES, each is rated to release a mass of gas mixture of at least $2 \mathrm{kPa}-\mathrm{m}^{3}$. The gas is injected into the vacuum vessel through guide tubes located in the port plugs; the valve outlet stainless steel tubes are about 1-m length and all have a slight bend to prevent direct line-of-sight so that plasma radiation does not directly shine on the valve. The total amount of injected gas in one DMS actuation is limited to: Argon $-100 \mathrm{kPa}-\mathrm{m}^{3}$, Neon $-100 \mathrm{kPa}-\mathrm{m}^{3}$; Deuterium $-50 \mathrm{kPa}-$ $\mathrm{m}^{3}$; and Helium $-40 \mathrm{kPa}-\mathrm{m}^{3}$. The Gas Distribution System in the ITER plant supplies these gases to the DMS. The DMS is designed to operate for 4,000 events. Target gas pressure shall nominally be 1 bar upon entry into the vacuum vessel. The MGI system is designed so that it can discharge its injection gas inventory into the vacuum vessel following plasma operations if the DMS was not operated in the preceding plasma. Discharge into the vessel is the means by which the DMS is 'safed' until its next usage period.

The gas reservoir in one gas holding valve is 1 liter volume and is charged to 40 bar when the DMS is prepared for operation. The design calls for four thermal mitigation MGI valve assemblies to be located in upper port plugs, and two runaway electron valve assemblies to be located in the equatorial port plugs. There are two runaway electron systems, the runaway electron suppression system (RES) mentioned above and the runaway electron dissipation system (RED). The RES and RED valves can have staggered valve actuation to enhance their effectiveness. The RES and RED are located in the same equatorial port plug. The thermal mitigation MGI valves will be instantaneously triggered from signals from the tokamak diagnostics system via the Central Interlock System, they will inject gas within 5 ms. Figure 2-1 shows the components in the thermal mitigation DMS. Figure 2-2 shows the expected position of a DM valve in a port plug. Figure 2-3 shows the DM valve actuation circuit (trigger electronics) layout. Figure 2-4 shows a cutaway of a DM valve. Table 2-1 lists the components in the TM MGI DMS.

The MGI DMS is allowed 3 hours to reset after an actuation, so compressors taking feed from the Gas Distribution System can recharge all DM valves with the correct gas mixture and 40 bar pressure. As shown in Figure 2-1, the deuterium compressor and gas metering valves are in the port cell rather than the port plug. The other gas compressors are outside the port cell, feeding in the resupply gas via small diameter piping. The three-hour time also allows trickle charge of the capacitor banks that provide energy to open the DM valves (Baylor, 2012). 


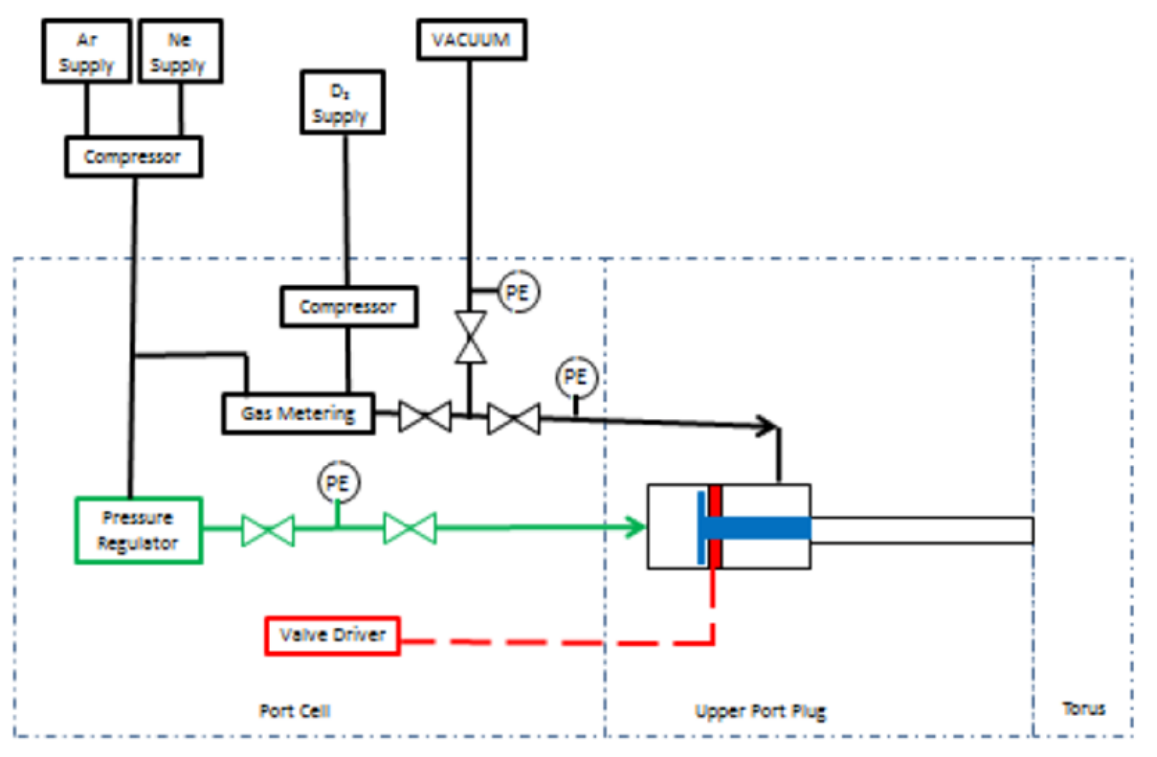

Figure 2-1. Flow schematic diagram of a single thermal mitigation DMS valve (Baylor, 2012).

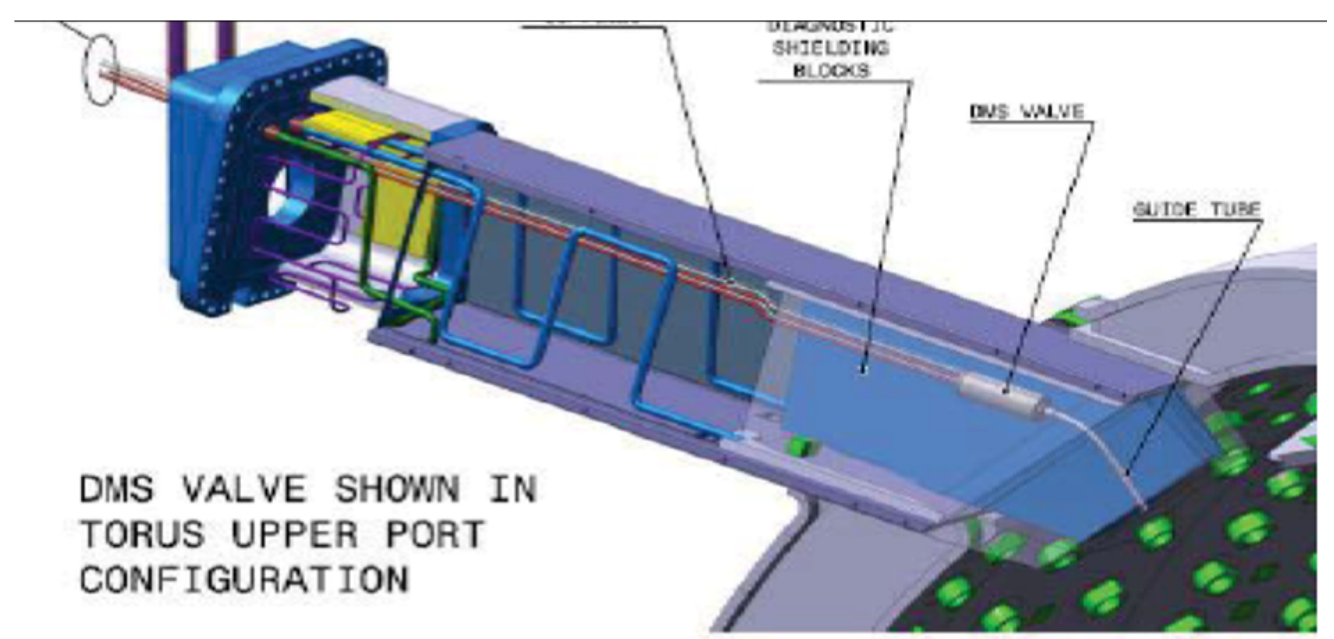

Figure 2-2. Location of a thermal mitigation DMS valve in an upper port plug (Baylor, 2012). 


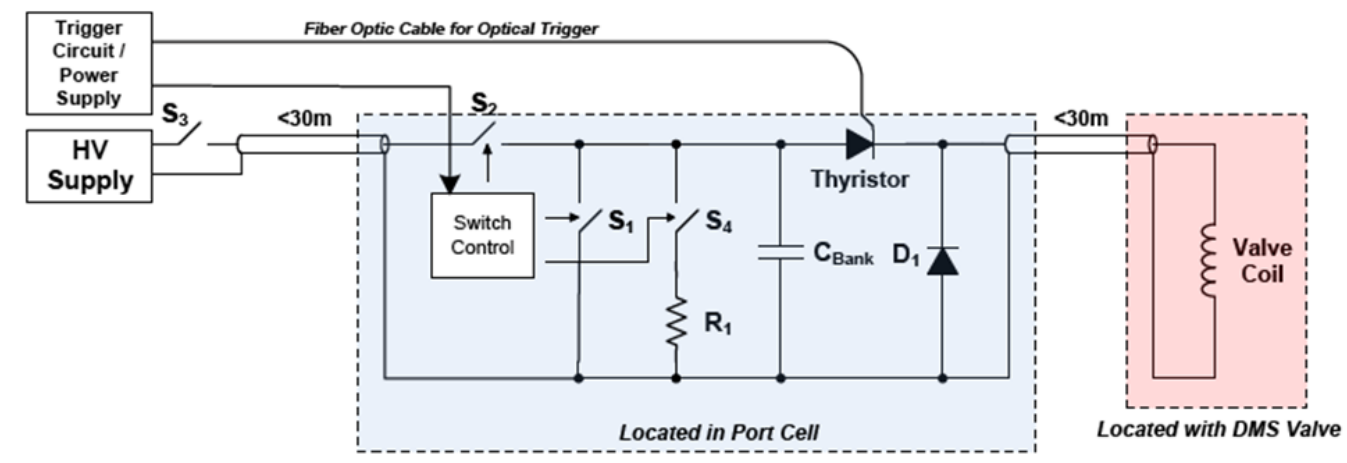

Figure 2-3. Sketch of the Fast Valve Triggering Electronic System (Baylor, 2012).

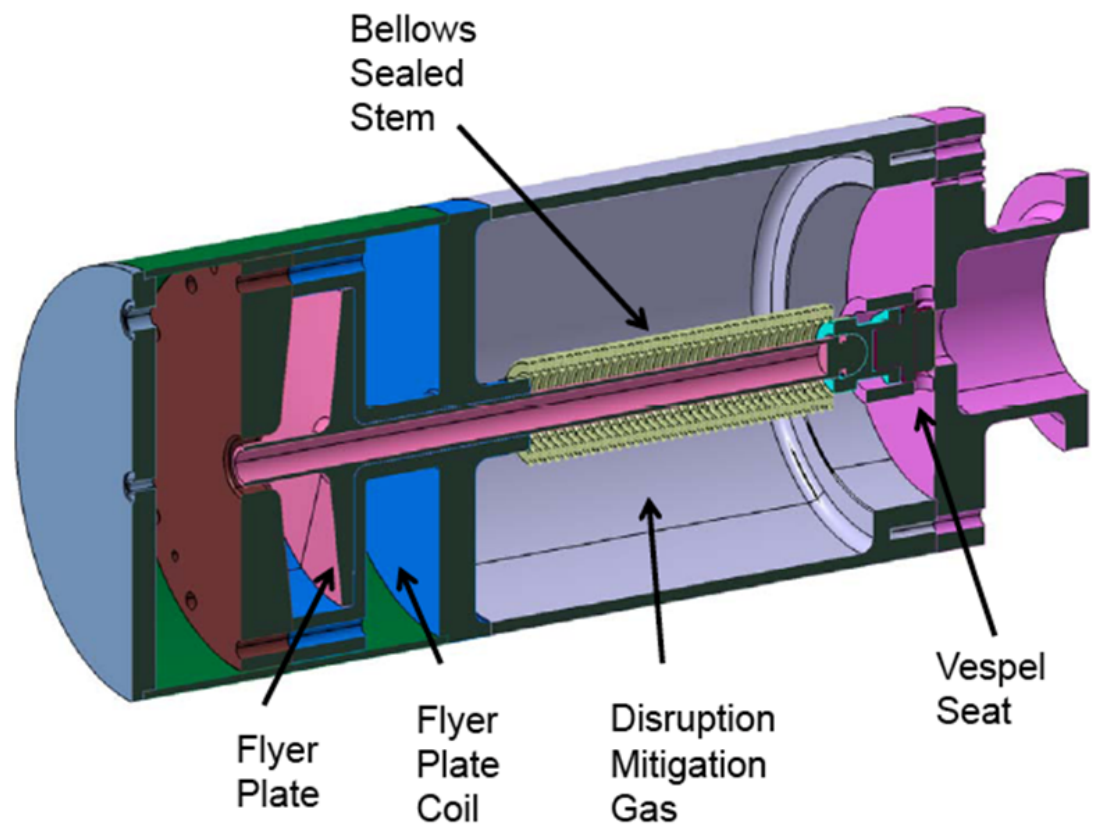

Figure 2-4. MGI DM valve concept for ITER (Baylor, 2013). 
Table 2-1. Thermal Mitigation DMS component list.

\begin{tabular}{|c|c|c|c|}
\hline Component description & Component identifier & Component function & Component count \\
\hline $\begin{array}{l}\text { Argon and Neon } \\
\text { compressor, type } \\
\text { unknown, assume low or } \\
\text { no oil type (perhaps a } \\
\text { diaphragm compressor) }\end{array}$ & Comp-1 & $\begin{array}{l}\text { Compress } \mathrm{Ar}, \mathrm{Ne} \text { to } 40 \\
\text { bar to charge the DMS } \\
\text { valves }\end{array}$ & 4 \\
\hline $\begin{array}{l}\text { Argon and Neon } \\
\text { pressure regulator }\end{array}$ & Reg-1 & $\begin{array}{l}\text { Regulate } \mathrm{Ar}, \mathrm{Ne} \text { gas } \\
\text { pressure for DMS valve } \\
\text { closure volume }\end{array}$ & 4 \\
\hline $\begin{array}{l}\text { Gas valve near } \\
\text { regulator, assume motor } \\
\text { operated valve }\end{array}$ & Valve-1 & $\begin{array}{l}\text { Isolates pressure } \\
\text { regulator, routes gas to } \\
\text { DMS valve closure } \\
\text { volume }\end{array}$ & 4 \\
\hline $\begin{array}{l}\text { Pressure element or } \\
\text { sensor in Ar-Ne gas line }\end{array}$ & PS-1 & Monitor gas pressure & 4 \\
\hline $\begin{array}{l}\text { Gas valve in series from } \\
\text { regulator, assume motor } \\
\text { operated valve }\end{array}$ & Valve-2 & $\begin{array}{l}\text { Isolates pressure } \\
\text { regulator and PS-1, } \\
\text { routes gas to DMS valve } \\
\text { closure volume }\end{array}$ & 4 \\
\hline $\begin{array}{l}\text { Deuterium compressor, } \\
\text { type unknown, assume } \\
\text { low or no oil type } \\
\text { (perhaps a diaphragm } \\
\text { compressor). }\end{array}$ & Comp-2 & $\begin{array}{l}\text { Compress } D_{2} \text { gas to } 40 \\
\text { bar to charge the DMS } \\
\text { valves }\end{array}$ & 4 \\
\hline $\begin{array}{l}\text { Gas metering device } \\
\text { (assume mass flow } \\
\text { controller) }\end{array}$ & Meter-1 & $\begin{array}{l}\text { Provide gas to DMS } \\
\text { valve 1-liter chamber }\end{array}$ & 4 \\
\hline $\begin{array}{l}\text { Gas valve near meter, } \\
\text { assume motor operated } \\
\text { valve }\end{array}$ & Valve-3 & $\begin{array}{l}\text { Isolates gas meter line } \\
\text { from vacuum line and } \\
\text { DMS valve }\end{array}$ & 4 \\
\hline $\begin{array}{l}\text { Gas valve in vacuum } \\
\text { line, assume motor } \\
\text { operated valve }\end{array}$ & Valve-4 & Isolates vacuum line & 4 \\
\hline $\begin{array}{l}\text { Pressure element or } \\
\text { sensor in vacuum line }\end{array}$ & PS-2 & Monitor vacuum level & 4 \\
\hline $\begin{array}{l}\text { Gas valve in series from } \\
\text { gas metering }\end{array}$ & Valve-5 & $\begin{array}{l}\text { Isolates DMS valve from } \\
\text { metering and vacuum } \\
\text { lines }\end{array}$ & 4 \\
\hline $\begin{array}{l}\text { Pressure sensor in Ar- } \\
\mathrm{Ne}-\mathrm{D}_{2} \text { line }\end{array}$ & PS-3 & $\begin{array}{l}\text { Monitor line pressure to } \\
\text { DMS valves }\end{array}$ & 4 \\
\hline DMS valve & DM-1 & $\begin{array}{l}\text { The gas reservoir valve } \\
\text { that delivers } \mathrm{MGI} \text { to the } \\
\text { plasma }\end{array}$ & 4 \\
\hline Gas piping in port plug & $\begin{array}{l}\text { Piping-1, treated as one } \\
\text { component }\end{array}$ & $\begin{array}{l}\text { Small diameter pipe that } \\
\text { routes gases in the port } \\
\text { plug }\end{array}$ & $\begin{array}{l}\text { Assume } 6 \text { meters in } \\
\text { each of } 4 \text { locations }\end{array}$ \\
\hline Gas piping in port cell & $\begin{array}{l}\text { Piping-2, treated as one } \\
\text { component }\end{array}$ & $\begin{array}{l}\text { Small diameter pipe that } \\
\text { routes gases in the port } \\
\text { cell }\end{array}$ & $\begin{array}{l}\text { Assume } 30 \text { meters in } \\
\text { each of } 4 \text { locations }\end{array}$ \\
\hline
\end{tabular}


Table 2-1. Thermal Mitigation DMS component list, continued.

\begin{tabular}{|c|c|c|c|}
\hline Component description & Component identifier & Component function & Component count \\
\hline $\begin{array}{l}\text { Vacuum piping in port } \\
\text { plug }\end{array}$ & Vpiping-1 & $\begin{array}{l}\text { Vacuum purge for DM } \\
\text { valve }\end{array}$ & $\begin{array}{l}\text { Assume } 6 \text { meters in } \\
\text { each of } 4 \text { locations }\end{array}$ \\
\hline $\begin{array}{l}\text { Vacuum piping in port } \\
\text { cell }\end{array}$ & Vpiping-2 & $\begin{array}{l}\text { Vacuum purge for DM } \\
\text { valve }\end{array}$ & $\begin{array}{l}\text { Assume } 30 \text { meters in } \\
\text { each of } 4 \text { locations }\end{array}$ \\
\hline $\begin{array}{l}\text { Trigger circuit power } \\
\text { supply }\end{array}$ & TCPS & $\begin{array}{l}\text { DC power to trigger } \\
\text { circuit }\end{array}$ & 4 \\
\hline Switch 1 & $\mathrm{~S}_{1}$ & $\begin{array}{l}\text { Valve actuation circuit } \\
\text { safety switch }\end{array}$ & 4 \\
\hline Switch 2 & $\mathrm{~S}_{2}$ & $\begin{array}{l}\text { Control line power to } \\
\text { capacitor bank }\end{array}$ & 4 \\
\hline Switch 3 & $\mathrm{~S}_{3}$ & $\begin{array}{l}\text { Control line power to } \\
\text { valve actuation circuit }\end{array}$ & 4 \\
\hline Switch 4 & $\mathrm{~S}_{4}$ & Thyristor reset switch & 4 \\
\hline Resistor 1 & $\mathrm{R}_{1}$ & $\begin{array}{l}\text { Dissipate power in valve } \\
\text { actuation circuit }\end{array}$ & 4 \\
\hline Capacitor bank & $\mathrm{C}_{\text {Bank }}$ & $\begin{array}{l}\text { Store electrical energy in } \\
\text { valve actuation ckt }\end{array}$ & $\begin{array}{l}\text { Treat bank as one unit, } 4 \\
\text { banks }\end{array}$ \\
\hline Thyristor & $\mathrm{T}_{1}$ & $\begin{array}{l}\text { Opens to conduct } \\
\text { electricity to DM valves }\end{array}$ & 4 \\
\hline Diode & $\mathrm{D}_{1}$ & $\begin{array}{l}\text { Conduct electricity in } \\
\text { one direction in ckt }\end{array}$ & 4 \\
\hline $\begin{array}{l}\text { Electrical instrument } \\
\text { wire/cable }\end{array}$ & $\begin{array}{l}\text { W, treated as one } \\
\text { component }\end{array}$ & $\begin{array}{l}\text { Carry electrical } \\
\text { instrument signals in ckt }\end{array}$ & $\begin{array}{l}\sim 30 \mathrm{~m} \text { at each of } 4 \\
\text { locations }\end{array}$ \\
\hline $\begin{array}{l}\text { Electrical cable in port } \\
\text { plug }\end{array}$ & $\begin{array}{l}\text { C-1, treated as one } \\
\text { component }\end{array}$ & $\begin{array}{l}\text { Carry HV electrical } \\
\text { current in ckt }\end{array}$ & $\begin{array}{l}\sim 30 \mathrm{~m} \text { at each of } 4 \\
\text { locations }\end{array}$ \\
\hline $\begin{array}{l}\text { Electrical cable in port } \\
\text { cell }\end{array}$ & $\begin{array}{l}\text { C- } 2 \text {, treated as one } \\
\text { component }\end{array}$ & $\begin{array}{l}\text { Carry HV electrical } \\
\text { current in ckt }\end{array}$ & $\begin{array}{l}\sim 100 \mathrm{~m} \text { at each of } 4 \\
\text { locations }\end{array}$ \\
\hline Fiber optic cable & FOC & $\begin{array}{l}\text { Carry trigger signal for } \\
\text { thyristor to close to send } \\
\text { current from capacitor } \\
\text { bank to DM valves }\end{array}$ & $\begin{array}{l}\sim 100 \mathrm{~m} \text { at each of } 4 \\
\text { locations }\end{array}$ \\
\hline $\begin{array}{l}\text { High voltage power } \\
\text { supply }\end{array}$ & HV Pwr Sup & $\begin{array}{l}\text { Supply energy to } \\
\text { capacitor bank }\end{array}$ & 4 \\
\hline
\end{tabular}




\subsection{DMS Operation}

ITER plans to conduct on the order of $\sim 3,000$ plasma pulses in a year. The DMS is armed to operate for each physics-type plasma pulse that is part of an operating session. The low power pulses performed for machine cleaning, testing and calibration, etc., in the third shift of an operating day do not require the DMS. Figures 2-1 and 2-2 show the thermal mitigation system schematic and the position of the thermal mitigation valve near the plasma periphery. The DMS is actuated by plasma diagnostics that send signals to the Central Interlock System, which gives an actuation signal to the trigger circuit shown in Figure 2-3. The MGI increases the electron density up to a critical value to completely suppress runaway electron avalanche amplification (RPrS, 2011).

It has been stated in ITER design work that plasma disruptions are part of normal operational events. Type I disruptions of $\sim 0.4$ GJ thermal energy and $\sim 0.35$ GJ of magnetic energy with a current quench of $54 \mathrm{~ms}$ and initial plasma current of 15 MA would occur 3,000 times during the life of ITER (GSSR, 2001). Type II disruptions would be worst case, fast disruptions with current quench time of $27 \mathrm{~ms}$ and 300 of these would be expected over ITER lifetime (GSSR, 2001). The ITER operating scenario is anticipated to be two or three shift plasma operation in 11 days +3 day maintenance outage, so 2 weeks for a plasma operation session (Blackler, 2011). In 16 months, there would be 34 such 2-week sessions, then an 8 month long maintenance outage. Assuming one plasma pulse of 400 seconds requires 1-hour of machine countdown, preparation, pulse, and recovery time, and 2-shift operation, then for 2 shifts $(16 \mathrm{~h} /$ day $)$ ITER could accomplish $(16 \mathrm{~h} /$ day $)(11$ days/session $)(1 \mathrm{pulse} / \mathrm{h})(34 \mathrm{sessions} / 2$ years $)$ or 2992 pulses per year on average. If ITER operates for 20 years, then there will be a total of $\sim 60,000$ plasma pulses. (Type I + Type II disruptions)/total pulses is $3,300 / 60,000=5.5 \%$ of plasma pulses end in some form of disruption, so the DMS may be actuated fairly often throughout an ITER operating year. Using the average 2992 pulses/year, then perhaps 165 pulses will end with a demand to actuate the DMS. While every other year has an 8-month outage, the average is 17 plasma sessions in a year, so the DMS actuates to discharge its pressurized gas into the vessel at the end of each plasma operating session.

The DMS is turned off for ITER long-term and short-term maintenance sessions (Maruyama, 2013). The DMS is operational during plasma operations and during ITER testing; it does not need to be operational for wall conditioning pulses. The DM system can be discharged into the vacuum vessel or it is purged via the vacuum line when it is de-armed (shut down) for ITER outages. If ITER enters a short-term maintenance in the third shift of an operating day, then presumably the system is discharged so that it is in safe mode.

To charge the system, the compressor operates, taking argon and neon gas feed from the piped gas supply systems in the ITER plant. The lines are pressurized to $40 \mathrm{bar}$ and the gas is routed through the gas metering device to the DM valve 1-liter reservoir and to the DM valve plenum for cushioning the plunger that opens the valve. Once charged, the DM valve gas inlet is closed and the valve is in readiness with pressure in the 1-liter reservoir and in the plunger plenum. The capacitor bank is charged with stored electrical energy from a high voltage power supply, this energy will flow to the DM valve when a signal is received. After a signal from the Central Interlock System, the thyristor closes and electrical energy from the capacitor bank flows to a coil in the valve, and the plunger moves under the action of the eddy current electromagnetic force created by the coil. The plunger movement starts the valve opening and the gas pressure in the valve reservoir assists in opening the valve further. Then gas in the DM valve reservoir flows out a 25 -mm diameter, $\sim 1 \mathrm{~m}$-long line to the plasma edge. 
The TM portion of the DM system is modeled here. The four TM locations each have their own argon-neon compressor, as described in Table 2-1. The TM system is very similar to the RES, although the RES may have fewer gas handling valves overall than the four stand-alone subsystems of the TM system shown in Figure 2-1.

The environmental conditions in the port plug and in the port cell room where the system components reside are given in Table 2-2.

Table 2-2. Normal Environmental Conditions for DM System Areas.

\begin{tabular}{ll}
\hline \multicolumn{1}{c}{ Area } & \multicolumn{1}{c}{ Normal Conditions (Ciattaglia, 2012) } \\
\hline Port plug & Pressure: $1 \mathrm{E}-04$ to $1 \mathrm{E}-07 \mathrm{~Pa}$ \\
& Temperature: $\sim 120 \mathrm{C}$ \\
& Humidity: $\mathrm{n} / \mathrm{a}$, vacuum conditions \\
& Radiation: $\sim 1 \mathrm{E}+11 \mathrm{n} / \mathrm{cm}^{2}-\mathrm{s}(14-\mathrm{MeV}$ neutrons), \\
& $\sim 1 \mathrm{E}+13 \mathrm{n} / \mathrm{cm}^{2}-\mathrm{s}(0.1 \mathrm{MeV}$ neutrons), \\
& $\sim 1 \mathrm{E}+13 \mathrm{gamma} / \mathrm{cm}^{2}-\mathrm{s}$ (from NAR, 2004) \\
& Magnetic field: $>150 \mathrm{mT}$ to $3.5 \mathrm{~T}$ \\
Equatorial and Upper port cells & Pressure: 140 Pa below atmospheric pressure \\
& Temperature: 5 to $35 \mathrm{C}$ \\
& Humidity: $<60 \%$ relative humidity \\
& Radiation dose rate: $1.44 \mathrm{E}-03 \mathrm{~Sv} / \mathrm{h}$ \\
& Magnetic field: 150 to $45 \mathrm{mT}$ \\
\hline
\end{tabular}

\subsection{Related Operating Experiences Supporting the FMEA}

The literature was searched for any applicable MGI uses. The prototype systems at the DIII-D, Mega-Ampere Spherical Torus (MAST), and Alcator C-MOD machines were reviewed for any operating experience data. The published discussions dwelt on the physics aspects of MGI and the efficacy of the systems in reducing disruption damage, not the engineering aspects of system operation. The Alcator system was qualitatively described as very reproducible, in terms of timing and amount of gas delivered (Granetz, 2006). The system was stated to be benign, posing no difficulties with breakdown or current ramp up on subsequent discharges, and also the gas jet operation was very reliable. Lehnan (2011) did not address operating experiences of the DM valve system on the JET experiment, he addressed the results of gas jetting into the vacuum vessel at the plasma periphery. Kruezi (2009) mentioned that the gas valves worked reliably on JET, so presumably this means that the gas system and valves functioned when they should and did not spuriously function to prematurely terminate a plasma shot.

Baylor (2013a) had collected engineering information about the operation of similar valves in use from the set of tokamaks listed above. These data are given in Table 2-3.

Sonato (1993) reported on a gas handling system connected to a reversed field pinch experiment (RFX). The gas handling system included hydrogen, deuterium, and helium gas for experiments (Bonizzoni, 1990), oxygen and noble gases for intentional impurity introduction, methane to carbonize the metal walls, and nitrogen to bring the vessel up to atmospheric pressure. The gas transfer system was plumbed from the gas bottle room to the experiment; it supplied fuel and other gases to the experiment. Programmable logic controllers (PLCs) controlled the system operations. The PLCs are part of the experiment's control and data acquisition system. 
Table 2-3. DM valve operations experience from existing tokamaks.

\begin{tabular}{|c|c|c|c|c|c|c|c|}
\hline $\begin{array}{c}\text { Fusion } \\
\text { experiment }\end{array}$ & $\begin{array}{l}\text { Number of } \\
\text { DM valves }\end{array}$ & $\begin{array}{c}\text { Type of } \\
\text { DM valves }\end{array}$ & $\begin{array}{c}\text { Number of } \\
\text { valve } \\
\text { failures }\end{array}$ & $\begin{array}{c}\text { Number of } \\
\text { valve } \\
\text { operations }\end{array}$ & $\begin{array}{l}\text { Operating } \\
\text { pressure } \\
\text { (Bar) }\end{array}$ & $\begin{array}{c}\text { Valve } \\
\text { seat leak } \\
\text { rate }(\mathrm{Pa}- \\
\left.\mathrm{m}^{3} / \mathrm{s}\right)\end{array}$ & Comments \\
\hline TEXTOR & 2 & $\begin{array}{l}\text { Eddy } \\
\text { current }\end{array}$ & 1 & $\sim 200$ & 1 to 30 & $\begin{array}{l}\text { 1E-06 } \\
\text { (helium) }\end{array}$ & $\begin{array}{l}\text { Top valve, } \\
\text { external } \\
\text { leak due to } \\
\text { coil feed- } \\
\text { through. } \\
\text { Changed } \\
\text { design. }\end{array}$ \\
\hline JET & $\begin{array}{c}1 \\
\text { (second } \\
\text { valve to } \\
\text { be added } \\
\text { in } \\
\text { October } \\
2013 \text { ) }\end{array}$ & $\begin{array}{l}\text { Eddy } \\
\text { current }\end{array}$ & 0 & 203 & 2 to 36 & $\begin{array}{l}\text { 1E-06 } \\
\text { (helium) }\end{array}$ & $\begin{array}{l}\text { Small } \\
\text { external } \\
\text { leak of } \\
\text { system, no } \\
\text { valve failure } \\
\text { in 2008- } \\
2013 \text {. Also, } \\
\text { JET has a } \\
2.5 \text { T } \\
\text { magnetic } \\
\text { field. }\end{array}$ \\
\hline DIII-D & 6 & Solenoid & 1 & 500 & 40 to 60 & $\begin{array}{l}1 \mathrm{E}-06 \text { or } \\
\text { less }\end{array}$ & $\begin{array}{l}\text { Valve seat } \\
\text { stuck in } \\
\text { holder, } \\
\text { assembled } \\
\text { incorrectly }\end{array}$ \\
\hline $\begin{array}{l}\text { Alcator C- } \\
\text { MOD }\end{array}$ & 2 & Solenoid & 0 & 200 & 40 to 60 & $\begin{array}{l}1 \mathrm{E}-06 \text { or } \\
\text { less }\end{array}$ & $\begin{array}{l}\text { Same valve } \\
\text { design as } \\
\text { DIII-D }\end{array}$ \\
\hline $\begin{array}{l}\text { Tore } \\
\text { Supra }\end{array}$ & 1 & Solenoid & 0 & 200 & - & 1E-08 & $\begin{array}{l}\text { Some valve } \\
\text { leakage } \\
\text { required } \\
\text { firing valve } \\
\text { to seal } \\
\text { Teflon o-ring } \\
\text { seal. }\end{array}$ \\
\hline $\begin{array}{l}\text { ASDEX } \\
\text { Upgrade }\end{array}$ & 2 & Solenoid & 0 & 10,000 & 5 to 12 & 1E-09 & $\begin{array}{l}\text { Viton seal } \\
\text { maintained } \\
\text { once per } \\
\text { year }(\sim 1000 \\
\text { shots) for } 10 \\
\text { years. }\end{array}$ \\
\hline KSTAR & 1 & Solenoid & 0 & $\sim 50$ & 40 to 50 & $1.4 \mathrm{E}-11$ & \\
\hline \multicolumn{8}{|c|}{$\begin{array}{l}\text { The two most similar valves are from TEXTOR and JET, so } 1 \text { failure, and }(2 \text { valves } \bullet 200 \text { actuations })+(1 \text { valve } \bullet 203 \\
\text { actuations) gives a point estimate } \lambda=1 /(400+203) \text { or } \lambda=1.66 \mathrm{E}-03 \text { per valve actuation demand. The spurious operation } \\
\text { failure mode calculation: assuming } 1 \text { actuation per } 8 \text {-h pulse day, and no spurious operations listed in the table, then } \lambda= \\
0.5 / \mathrm{T} \text { (Atwood, } 2003) \text {, where T is the total unit hours of operation. Then } 0.5 /(2 \text { valves } \bullet 200 \text { actuations } 8 \mathrm{~h} / \text { actuation })+(1 \\
\text { valve } \cdot 203 \text { actuations } \bullet 8 \text { h/actuation }) ~ 1 \mathrm{E}-04 / \text { valve-hour. There were no valve plugging events reported, so the same } 1 \mathrm{E}- \\
04 / \text { valve-hour applies to the plugging failure mode. }\end{array}$} \\
\hline
\end{tabular}

Standard industrial components that operate in non-standard environments were tested to assure operability and reliability in the new environment. For specialty components, several tests were performed: magnetic permeability, dimensional tests, cleaning procedures were tested, pressure test, component leak rate and integral leak rate tests. The gas lines had a maximum pressure of 2 bar, so they were tested at 4 bar absolute for 10 minutes, then the lines were evacuated. This was repeated four times for the leak test. The system had to operate in the 
presence of magnetic fields, which induce voltages and currents along the metallic piping. These induced energies can lead to arcs and overheating. Magnetic forces are generated in ferromagnetic parts. The magnetic circuits of electromechanical devices can be saturated as well. The RFX used ceramic and polytetrafluoroethylene (e.g., Teflon) vacuum insulators in the metal piping to prevent loop currents. Gas valves were electro-pneumatic, and had a response to magnetic fields. These valves used a solenoid to control the motive-power gas flow to the valve actuator. In a magnetic field parallel to the axis of the coil, there was interference. In a range of $20 \mathrm{mT}$ to $45 \mathrm{mT}$, the field created in the solenoid was reduced and valve operation was compromised. With this knowledge from testing, the valves were placed with the solenoid axis orthogonal to the magnetic field direction, making the threshold magnetic field value to affect the valves over $100 \mathrm{mT}$. For those gas valves that had to operate close to the RFX, in greater than $100 \mathrm{mT}$ zones, a two-layer soft iron magnetic shield was designed to protect the solenoid coil. The gas handling system functioned well during testing, followed by an extensive machine commissioning period, and the system also gave $100 \%$ availability in the first year of RFX operation.

Yang (2010) discussed the ITER fuel gas injection system. Noteworthy challenges are high gamma radiation and magnetic field exposure $(\sim 200 \mathrm{mT})$ for the flow control valves. Mass flow controllers might be used if they can be placed in magnetic shields to reduce their magnetic field exposure.

Childs (1993) discussed the gas delivery system for the Alcator C-Mod tokamak. The system functioned well, even when there were power outages that would shut the system down. When de-powered the system de-energizes to a safe state.

Villaran (1990) discussed power plant instrument air systems, which are designed to provide a reliable, high quality air supply for plant uses, including breathing air, instrumentation, and testing needs. Villaran also discussed failure causes and mechanisms in these systems, which is of interest for the FMEA of the DM system. Moisture in air, particulates in the vents, and hydrocarbon contamination have caused a considerable number of air system failures. Filters were degraded by moisture, dust, particulates from the system (corrosion from piping, weld beads or slag, etc.). System instrument air lines were clogged by hydrocarbons, dirt, moisture - which caused faulty indication and erroneous control signals in those systems. Oil leaks led to hydrocarbons on valve seals, causing the seals to become brittle and stick to mating surfaces. Seal disintegration led to particulate from the seals spreading in the system. Rust in the piping and equipment caused by moisture in the gas has been dislodged in severe vibration events (flowinduced pressure pulsations, or equipment induced vibration), causing problems with valve seats. Polymeric seals in accumulator tanks and compressors degrade with time and have leaked gas to the room atmosphere. Given the importance of impurities in these systems, it should be noted that cleanliness in the gas supply and the DM pipework must be established not only for reliable system operation but also to preclude ingress of impurities into the vacuum vessel. Impurities could be incompatible with maintaining vacuum or could react with in-vessel materials. Granted, the $\sim 28$ liters of gas in the MGI DM system are few compared to the $\sim 800 \mathrm{~m}^{3}$ vacuum vessel and impurities could be measured in the ppm range within the 28 liters, but cleanliness remains an important issue since the DM system could be actuated more than 165 times in a year. Finken (2001) discussed that the injection gases themselves have had effects on the next plasma pulse at TEXTOR. Injecting large amounts of hydrogen isotopes at TEXTOR generally load onto the walls so that special measures must be taken to release the gas stored in and on the walls. Heavier impurities may show up in the startup phase of the next plasma pulse and lead to poor performance of the pulse. However, it is noted that TEXTOR (major radius of $1.75 \mathrm{~m}$ ) is not 
nearly as large a machine as ITER, and the ITER DM designers are confident that the liters of gas injected for a mitigation will not spoil the following plasma pulses (Lyttle, 2013).

Gray (1969) discussed the Dragon fission reactor helium cooling system operating experiences. Some of the Dragon valves showed sticking behavior of metal valve disks to metal seats when they were opened after remaining closed for long periods of time. The valves exhibiting sticking phenomena were modified so the motor operators on these valves would deliver a shock when opening to break the metal-metal contact. There were no problems with valve 'sticking' after that modification. Since the DM gas valve uses a vespel seal rather than metal-on-metal, this type of "sticking" failure event should not be an issue for the DM system.

\subsection{FMEA Failure Rate Data}

The component failure rate data used in the FMEA came from several sources. The ITER Project has an approved component failure rate database, but the database typically addresses larger components than 1-liter gas volumes, and piping larger than the tubing used in this system (less than 25-mm diameter). There are data sources for gas pipelines (ambient temperature, $\sim 600$ to 1000 psig natural gas) used in the commercial energy industry but these components also vary widely from the system of interest. Data was found from published data sources believed to be most applicable to the DM components. Adjustments were made to account for the environment of the location where the DM system resides. Data sources for components of medium pressure compressed air and gas systems included Blanton (1998) and Hale (2001). Other data sources included Denson (1996), Dexter (1982), Mahar (2011), and Volotinen (1999). Failure rate data source citations found in the FMEA table pages in Appendix A are cited in the references section of this chapter.

Information discussed in section 2.2 allows calculation of DM system demands per year, which is important for the DM valves and the other equipment that must start or function on demand. On average there are an estimated 165 disrupting pulses per year, and an assumed 17 operator discharges of the DM system at the end of 2-week pulse sessions, or 182 actuations. There may be other discharges actuated from the control room during the two-week campaigns to 'safe' the system if there is short-term maintenance to be conducted in the third shift of the day. As a first estimate of such pulses, another 18 discharges are assumed as $\sim 10 \%$ of third shift count in a year. Therefore, the total is 200 system actuations/year - this is about 1 actuation per operating day. ITER will operate on average for 2,992 hours or roughly 3,000 hours each calendar year. These system demand and operating hour values will be used with the failure rate data listed in Appendix A to determine the annual probability of failure, which will set the occurrence (the $\mathrm{O}$ value) of the criticality value.

The aggressive environments of the port cell and the port plug must be accounted for. Table 2-2 gave the normal operating environments for these two areas. The port cell is not very different from a fission reactor containment building conditions. The fission reactor containment building averages $39.7^{\circ} \mathrm{C}\left(103.5^{\circ} \mathrm{F}\right)$ (Guyer, 1982). The air pressure and humidity in the fission reactor containment building are not greatly different than atmospheric conditions. The fission containment pressure typically tends to vary between 1070 and $960 \mathrm{mbar}$ (Dey, 1995). The radiation conditions in a fission reactor containment building are 20-year neutron fluences of $1 \mathrm{E}+13$ to $1 \mathrm{E}+14 \mathrm{n} / \mathrm{cm}^{2}$, and gamma fluences of $1 \mathrm{E}+15$ to $1 \mathrm{E}+19$ gamma $/ \mathrm{cm}^{2}$ (Cadwallader, 2013). Some failure rate multipliers for the fission reactor containment building environment are given in Table 2-4 below (Cadwallader, 2013). It is noted that these $\mathrm{k}$ factor multipliers reported for the containment building environment tend to be modest values. For blowers and motors, the $\mathrm{k}$ factor was 1 . For transformers and valve actuators the values vary from 1 to 1.57 and 1 to 2.06 , 
respectively. These small multipliers will not be a large effect on the occurrence frequency category in the FMEA, but the high end of the k factor range will be taken into account for the components in the port cell as a level of conservatism at this stage of the design. The magnetic field in the port cell is modest. The most susceptible components to magnetic fields would be the valve motors, compressor motors, and the mass flow controllers. However, as discussed by Sonato (1993), valve motors can accommodate $100 \mathrm{mT}$ and greater fields if they are aligned to be orthogonal to the magnetic field direction. Perhaps this is all that is needed to reduce stainless steel valve (and valve operator) susceptibility to magnetic fields in the port cell. The mass flow controller (MFC) will be susceptible to magnetic fields. The thermal-type MFC uses small wire heaters to warm a capillary tube and the flow of gas cools the tube so that the flow rate of gas

Table 2-4. Some failure rate modifiers for radiation environments.

\begin{tabular}{|c|c|}
\hline Component Type & K factor Failure Rate Multiplier \\
\hline Annunciators & 1.1 to 2.0 \\
\hline Batteries & 1.05 to 1.2 \\
\hline Blowers & 1.0 \\
\hline Circuit breakers & 1.17 to 5.0 \\
\hline Motors & 1.0 \\
\hline Heaters & 1.0 \\
\hline Transformers & 1.07 to 1.57 \\
\hline Valve actuators & 1.1 to 2.06 \\
\hline Instrumentation \& Controls & 1.0 to 1.25 \\
\hline Cables & 2.0 to 3.7 \\
\hline \multicolumn{2}{|c|}{$\begin{array}{l}\text { Note: The radiation environment is that found in the interior of a containment building } \\
\text { of a nuclear fission power plant. This environment includes both MeV gamma and } \\
10-100 \mathrm{keV} \text { neutron fluxes. The combined radiation field is on the order of } 0.1 \text { to } \\
0.25 \mathrm{~Sv} / \mathrm{hr} \text {, where } \approx 10 \% \text { is due to neutrons and the remainder is gamma radiation. }\end{array}$} \\
\hline
\end{tabular}

is known (Hoffman, 1998). These heater wires attached to the capillary tube will experience magnetic induction, changing the amount of heating to the capillary tube. It is noted that Sonato (1993) stated that some RFX components in $100 \mathrm{mT}$ fields were shielded to reduce the magnetic field effects by the use of double-walled soft iron plate shields that surrounded the component. Perhaps the MFC can be shielded in this manner or by some other sort of enclosure since there is space in the port cell to allow such enclosures. The iron plates would also provide a slight amount of radiation shielding, since MFCs are not noted for radiation hardness. Hoffman (1998) also stated that the capillary tube being horizontal orientation is important for proper operation, otherwise, "thermal siphoning" in a vertical orientation occurs - the gas buoyancy in this orientation allows a circulating flow to form in the sensor and bypass flow channels of the unit. Thus, the MFC should be designed for a horizontal position in the port cell. Hoffman (1998) also stated that MFCs usually operate in a 0 to $50^{\circ} \mathrm{C}$ environmental temperature range, which is met by the port cell atmospheric conditions given in Table 2-2. INL experience with MFCs is that the units can lose calibration in benign laboratory room environments, so a suggestion is that heavily used units should be calibrated every 6 months or more frequently, and moderately used units can be calibrated annually. This application would benefit from the 6-month calibration interval.

Korsah (2011) discussed magnetic field effects for components associated with the ITER cooling water system. One of these components was the strain-gauge type pressure gauge. These gauges had magnetic field tests performed and most of the control devices and measuring devices 
experienced magnetic susceptibility in the 5 to $20 \mathrm{mT}$ range. The type of pressure sensor to be used in the DM system is not identified, but there is the possibility of magnetic field susceptibility. The port cells, as noted in Table 2-2, will be in the 45 to $150 \mathrm{mT}$ range, so it is assumed that the design will call for shielding enclosures around each of the three pressure instruments located in the port cell if the selected sensor exhibits susceptibility to magnetic fields. For the component failure rate, it is assumed that the pressure sensors are not under the influence of magnetic fields.

For components in the port plug, Table 2-2 showed that the operating environment is much more severe - high temperature, vacuum, high radiation, and high magnetic field. The designers chose wisely to place passive components in the port plug, leaving the active components in the milder conditions of the port cell. The DM system valve and pipework in the port cell are more passive-type components that can tolerate the high temperature and vacuum conditions without requiring a $\mathrm{k}$ factor. Radiation damage to stainless steel was addressed in work done for stainless steel piping sheaths for in-vessel magnet coils (Cadwallader, 2013). In-vessel conditions are more severe than those in the port plug, but for conservatism at this stage of the DM design the in-vessel stainless steel sheath value of $1.7 \mathrm{E}-08 /$ hour-meter for small diameter $(58 \mathrm{~mm})$ pipe breach/leakage will be applied to the gas supply piping and vacuum piping that is routed to the $\mathrm{DM}$ valve in the port plug. This value was based on fast fission reactor core radiation exposure, so it is greater than the exposure in the port plug. Taking guidance from Blanchard (1998) the rupture failure rate is $(1.7 \mathrm{E}-08 / \mathrm{h}-\mathrm{m}) / 30$ or $5.7 \mathrm{E}-10 / \mathrm{h}-\mathrm{m}$, and plugging of the gas piping would be the same value as the rupture failure mode at $5.7 \mathrm{E}-10 / \mathrm{h}-\mathrm{m}$. The line length in the port plug to the DM valve is estimated to be $\sim 6 \mathrm{~m}$, and the exhaust line is $\sim 1 \mathrm{~m}$. The $1.7 \mathrm{E}-08 / \mathrm{h}-\mathrm{m}$ failure rate was calculated for $150^{\circ} \mathrm{C}$, which is close to the port plug operating temperature of $120^{\circ} \mathrm{C}$. No k factor is needed to adjust the failure rate for high temperature.

The DM valve itself is built of austenitic stainless steel for the valve body and it uses an aluminum plunger with a vespel polyimide seal. The electrical coil that drives the plunger accepts high electrical energy from the capacitor bank when actuated. Fortunately, actuations are low frequency ( $\sim 1$ /day) for this gas valve, so there is time for heat conduction to dissipate the heat that is generated by current in the coil when the DM valve is actuated. This valve is in a 3.5 Tesla magnetic field and a high temperature, low pressure, high radiation environment as defined in Table 2-2. The stainless steel could exhibit some increased magnetic permeability due to forming, welding, machining, cold work, etc., but this is difficult to quantify. Attaya (1984) discussed magnetic field effects of $3 \mathrm{~T}$ fields on HT-9 (a 12\% chromium and $1 \%$ molybdenum ferritic stainless steel) coolant piping. Attaya found that the magnetic forces on these ferromagnetic pipes were small compared to the coolant pressure (the coolant was lead-lithium, so the pressure was perhaps 3 or 4 bar, not nearly as high as in water coolant applications of up to 140 bar). Assuming that the HT-9 ferromagnetic steel results are an upper bound for austenitic stainless steel, then qualitatively the magnetic forces on the DM valve will be much less than those described by Attaya - and Attaya's magnetic forces were small compared to the coolant pressure forces. Therefore, as a first approximation, the magnetic field effects on the valve body, plunger, and seal are not significant. The valve coil may be susceptible since $3.5 \mathrm{~T}$ is a high magnetic field. Coil orientation will not reduce the effects of such a strong field, so the electrical energy surge into the coil is large to overcome any magnetic-field-induced energy created in the coil. The assumption is this coil is built to withstand the magnetic field. Typically, reliability discussions for electrical devices employing coils include the concept that increasing the temperature above the rated operating temperature causes premature failure of the insulation around the coil, leading to short circuit and even fire. Hubert (2003) described the "ten-degree half-life" rule, where the insulation life expectancy is decreased by half with each sustained duration operating session at $10^{\circ} \mathrm{C}$ above the normal operating temperature. The DM valve coil 
will be built with the $120^{\circ} \mathrm{C}$ environmental temperature and vacuum (no gas convection to cool the coil) as design requirements. And, if there was a short circuit, the 1E-04 Pa or lower pressure environment means there is greatly reduced oxygen present, so fire could not propagate in the coil or valve body.

The DM valve uses a vespel polyimide valve stem seat. Vespel has been tested and can accommodate up to $325^{\circ} \mathrm{C}$ operating temperature (Murari, 2004), so there is no temperature correction factor necessary. Vespel will undergo isotopic exchange with tritium even at room temperature (Clark, 2007). This effect needs to be investigated for any degradations to the vespel since there will be hundreds of grams of tritium in various states (adsorbed and absorbed on materials, free gas, constituent of gas molecules, etc.) in the ITER vessel. Also, the typical operating environment for the vespel is that the valve outlet line to the ITER vessel is under high vacuum, but if the vessel suffers a water leak then the vespel could be exposed to a steam environment. A literature search was conducted but no data were found on vespel degradation due to steam exposure at any temperature. This effect should be investigated to determine if the valve stem seals would be degraded by an ITER accident event. Polyimides like vespel are reputed to be radiation resistant, in the $1 \mathrm{E}+07$ to $1 \mathrm{E}+09$ Grays (Bruce, 1981), and vespel showed very little change in its material properties at 3E+07 Grays (Tavlet, 1998). Given this information, there is no radiation damage $\mathrm{k}$ factor estimated for the valve seal. It is noted that vespel has been used as a valve seat seal in gas systems at the Joint European Torus with success; the researchers there tested vespel valve stem tips for stainless steel gas valves to 50,000 openclose cycles of the valves and there was no detectable gas leak across the valve seat (Hemmerich, 1989); the vespel seal valves also gave good service over several years (Hemmerich, 1992).

Using the reported test data to apply to the DM valve, an estimate of 200 demands $/ 3,000$ hours is used. With the failure rate formula from Atwood (2003), this gives $\lambda=0.5 /(50,000$ cycle demands $\bullet 3000 \mathrm{~h} / 200$ demands) or $\sim 7 \mathrm{E}-07 /$ hour as a first estimate of the failure rate for a stainless steel valve with vespel seal leaking past the seat. Following guidance from Blanchard (1998) the seal rupture failure rate should be 20 times less at 3.5E-08/hour. There is also a bellows along the plunger shaft to keep the valve closure plenum separate from the valve injection gas reservoir. There are no compiled operating experience data on irradiated bellows. Typically, bellows life is given by the rated number of compression-extension cycles the unit can withstand before fatigue or other failure. This value is at present not known for the bellows. Assuming that the typical industrial design practice of specifying additional cycle life margin for these units is done, then handbook data will be applied to the bellows. Cherry (2001) stated that stainless steel bellows should function well up to a radiation threshold of $1 \mathrm{E}+19 \mathrm{n} / \mathrm{cm}^{2}$ where neutrons begin to effect metals. Using Table 2-2, the bellows would be two times that threshold fluence at the end of a 20-year life; however, ITER will not operate at high fluence for its entire lifetime. At this time, a bellows failure rate from industrial operations will be used without modifiers. A 'ground fixed' all-modes failure rate for bellows is $4.3 \mathrm{E}-06 / \mathrm{h}$ (Mahar, 2011). Failure mode distributions are given by Fields (2012). For bellows, 33.3\% is mechanical failure, 33.3\% is described as worn (which is very close to mechanical failure), $27.8 \%$ is induced failure (workers damage, cut or puncture the bellows), and 5.6\% is unknown failure. Assuming thorough inspection of the bellows when installed in the valve and careful handling to install the valve in the port plug, then the $27.8 \%$ can be removed, leaving $3.1 \mathrm{E}-06 / \mathrm{h}$ for bellows leakage. A factor of 10 reduction in that value is assumed (see Eide, 1991) to quantify the rupture failure mode. To address the valve body failure modes of leak and rupture to the port plug, it is noted that this valve is a special design, the valve is a cylinder shape like a pipe and it is constructed of reasonably thick-walled stainless steel. Therefore, a stainless steel pipe section (assume 0.5 -meter length and $150 \mathrm{~mm}$ diameter, and $7.11 \mathrm{~mm}$ wall thickness) will be used to obtain estimates of the valve body failure mode of leakage. Borrowing data from Cadwallader (2013), high irradiation stainless steel tubing of small size at $\sim 150^{\circ} \mathrm{C}$ is a failure rate of $1.5 \mathrm{E}-08 / \mathrm{h}-\mathrm{m}$. From Cadwallader (2013) a k factor to 
adjust for size is $(3.66 \mathrm{~mm})(7.11 \mathrm{~mm})^{2} /(150 \mathrm{~mm})(0.3 \mathrm{~mm})^{2}$ or 13.7. Therefore, the leakage failure rate would be $(0.5 \mathrm{~m})(2 \mathrm{E}-07 / \mathrm{h}-\mathrm{m})=1 \mathrm{E}-07 / \mathrm{h}$. Rupture would be at least a factor of ten reduction (see Eide, 1991), or a failure rate of $1 \mathrm{E}-08 / \mathrm{h}$.

The thyristor is an important part of the trigger circuit. Most thyristor reliability data is hourly operation rather than transferring from off to on or vice versa. Reviewing the literature, data from Alcator C-MOD (Fairfax, 1993) has given this information: twelve thyristor units in the poloidal field coil power system, operating at $4 \mathrm{kV}$ and $50 \mathrm{kA}$, operated over 1000 plasma shot demands with only a few failures (some fuses opened, they were changed out to higher ratings). Assuming that 'a few' means 3 failures, then a demand failure rate for thyristors to change from off to on is 3 failures/(12 units $\bullet 1,000$ demands $)=2.5 \mathrm{E}-04 /$ thyristor-demand. It is noted that the Alcator machine does not create high neutron fluence, and the operating environment is that of an industrial building. Therefore, this value is modified with a $\mathrm{k}$ factor of 1.25 to account for the port cell environment, giving 3.125E-04/thyristor-demand.

\subsection{MGI DM Preliminary FMEA}

The MGI DM system FMEA covered the system schematic diagrams shown in Figures 2-1 and 2-3. The pressurized "armed" operating mode during plasma pulses was treated. This was chosen based on the idea that ITER could wait in standby to begin a campaign if the DM system was not able to pressurize (also referred to as charge) its gas reservoirs during machine preparations for pulsing.

Many FMEAs use the risk priority number (RPN) approach given in IEC 60812 (IEC, 2006) to describe the criticality or importance of each component failure mode as given in the analysis. The RPN is the product of three values, $\mathrm{S}$, the severity of the failure, $\mathrm{O}$, the occurrence frequency of the failure, and $\mathrm{D}$, the detection of the failure. Therefore, $\mathrm{RPN}=\mathrm{S} \cdot \mathrm{O} \cdot \mathrm{D}$. Assigning numerical values to $\mathrm{S}, \mathrm{O}$, and $\mathrm{D}$ is semi-subjective. It is noted that the ITER project has defined the criticality of a failure as the product of only $\mathrm{S} \bullet \mathrm{O}$. The qualitative values 1 through 6 were defined to use for $\mathrm{S}$ and $\mathrm{O}$ so that criticality can be calculated. Tables 2-5 and 2-6 below show criteria for assigning S and O numerical values (van Houtte, 2009). For this analysis, it is assumed that any portion of the MGI system is necessary (that is, $100 \%$ system operation for success) so that any component fault or failure that requires repair is affecting the entire system, and the individual component repair time affects the entire system availability. As the system design matures, system success criteria will be better defined and this assumption can be revisited. It is also noted that the ITER Project Requirements state that personnel entry into the port cells for hands-on maintenance should allow decay time for the radiation dose rate to decrease to $100 \mu \mathrm{Sv} / \mathrm{h}$. This radiological safety hold time was estimated to be 12 days (Chiocchio, 2010). Thus, any entry into the port cell for repair is estimated to take the repair time plus 12 days. The 12 days was not accounted for in the FMEA since all failure severities would have been $S=4$ due to the ranking scheme and the fact that most repair times are measured in hours. Fixing $S=4$ would not have allowed any insight to failure criticality of the system components. 
Table 2-5. Failure Mode Severity for System Outage.

\begin{tabular}{llc}
\hline \multicolumn{1}{c}{ Severity } & \multicolumn{1}{c}{ Criteria } & S Ranking \\
\hline Weak, 1 hour & Unavailable < 1 hour & 1 \\
Moderate < 1 day & Unavailable between 1 hour and 1 day & 2 \\
Serious < 1 week & Unavailable between 1 day and 1 week & 3 \\
Severe < 2 months & Unavailable between 1 week and 2 months & 4 \\
Critical < 1 year & Unavailable between 2 months and 1 year & 5 \\
Catastrophic > 1 year & Unavailable more than 1 year & 6 \\
\hline
\end{tabular}

Table 2-6. Failure Mode Occurrence Frequency.

\begin{tabular}{llc}
\hline \multicolumn{1}{c}{ Occurrence } & \multicolumn{1}{c}{ Probability Criteria } & O Ranking \\
\hline Very low & Occurrence < 5E-04/year & 1 \\
Low & 5E-04/year < Occurrence < 5E-03/year & 2 \\
Moderate & 5E-03/year < Occurrence < 5E-02/year & 3 \\
High & 5E-02/year < Occurrence < 5E-01/year & 4 \\
Very high & 5E-01/year < Occurrence < 5/year & 5 \\
Frequent & Occurrence > 5/year & 6 \\
\hline
\end{tabular}

In Table 2-6, a time period of one operating year (that is $\sim 3,000$ hours) was selected as the time of interest for evaluating the component failure probability to set the $\mathrm{O}$ value. For the compressors, capacitor banks, and other demand equipment, the recharge time of 3 hours after each system demand, multiplied by 200 demands/year, was used with the demand failure rates. The DM system remains charged (or armed) through small outages and evenings of an 11-day plasma operating session, but it will be discharged in disruptions and at the end of each of the average value of $\sim 17$ plasma operating sessions each year.

ITER has defined criticality levels to ascertain the significance of the values found in the analysis (van Houtte, 2009). For ITER, an SxO less than or equal to 7 is defined as a minor risk with an optional need to take actions on risk reduction. An $\mathrm{SxO}$ of 8 to 12 is defined as a medium risk with mitigating actions recommended. An $\mathrm{SxO}$ of 13 or greater is defined as a major risk with actions being required. Actions to be taken can either be decreasing the Occurrence level or decreasing the Severity level, or both, to reduce the overall failure criticality level.

The FMEA tables are given in Appendix A. If needed, future work can expand the FMEA to cover other DM system operating modes and also address design changes as the system design matures. 


\subsection{References}

Air Liquide, 2010. Design and Safety Handbook for Specialty Gas Delivery Systems, $5^{\text {th }}$ edition, Air Liquide America Specialty Gases LLC, Plumsteadville, Pennsylvania, 2010.

ANSI, 2010. Flammability Characteristics of Combustible Gases and Vapors, ANSI/ISA-TR12-13-01-1999, American National Standards Institute, reaffirmed 2010.

Attaya, 1984. H. Attaya, G. L. Kulcinski, and W. G. Wolfer, "Analysis of Forces on Ferromagnetic Components Used in Magnetic Fusion Reactors," Journal of Nuclear Materials, 122-123 (1984) 96-100.

Atwood, 2003. C. L. Atwood et al., Handbook of Parameter Estimation for Probabilistic Risk Assessment, NUREG/CR-6823, Nuclear Regulatory Commission, Washington, DC (2003), chapter 6 .

Baylor, 2012. L. Baylor, Conceptual Design Description Document for the DMS ORNL Massive Gas Injection System, ITER IDM DCQYNS, December 1, 2012.

Baylor, 2013. L. R. Baylor, S. K. Combs, N. Commaux, P. W. Fisher, S. J. Meitner, M. Lyttle, D. A. Rasmussen, and S. Maruyama, "ITER Disruption Mitigation System Conceptual Design Review Highlights - Options for ITER," Oak Ridge National Laboratory, powerpoint presentation to the US Virtual Laboratory for Technology monthly conference call, January 16, 2013.

Baylor, 2013a. L. R. Baylor, Oak Ridge National Laboratory, e-mail communication of disruption valve operating experience data, August 27, 2013.

Beck, 2011. J. M. Beck, L. F. Pincock, High Temperature Gas-Cooled Reactors Lessons Learned Applicable to the Next Generation Nuclear Plant, INL/EXT-10-19329, revision 1, Idaho National Laboratory, April 2011.

Blackler, 2011. K. Blackler, Operations Handbook - 2 Operational States, ITER IDM 2LGF8N, April 27, 2011.

Blanchard, 1998. A. Blanchard and B. N. Roy, Savannah River Site Generic Data Base Development, WSRC-TR-93-262, rev. 1, Westinghouse Savannah River Company, May 1998.

Bonizzoni, 1990. G. Bonizzoni, F. Gnesotto, P. Sonato, and S. Vittura, "The vacuum and gas inlet systems for the RFX fusion experiment," Vacuum, 41 (1990) 1503-1507.

Bruce, 1981. M. B. Bruce, M. V. Davis, Radiation Effects on Organic Materials in Nuclear Plants, EPRI NP-2129, Electric Power Research Institute, November 1981, chapter 3.

Cadwallader, 1996. L. C. Cadwallader, Reliability Estimates for Selected Sensors in Fusion Applications, INEL-96/0295, Idaho National Engineering Laboratory, September 1996.

Cadwallader, 1999. L. C. Cadwallader, Liquid Metal, Gas, Molten Salt, and Organic Cooling System Operating Experience Review for Fusion Applications, INEEL/EXT-99-00144, Idaho National Engineering and Environmental Laboratory, February 1999. 
Cadwallader, 2001. L. C. Cadwallader, Operating Experience Review of In-Plant Electrical Distribution Systems for Fusion Applications, INEEL/EXT-01-01558, November 2001.

Cadwallader, 2013. L. C. Cadwallader, In-Vessel Coil Material Failure Rate Estimates for ITER Design Use, INL/EXT-13-28031, Idaho National Laboratory, January 2013.

Cherry, 2001. J. L. Cherry et al., Aging Management and Performance of Stainless Steel Bellows in Nuclear Power Plants, NUREG/CR-6726, US Nuclear Regulatory Commission, May 2001, chapter 4.

Childs, 1993. R. Childs, J. Goetz, M. Graf, A. Hubbard, J. Rice and T. Toland, "Design, control and operation of the vacuum and gas systems for Alcator C-Mod," Proceedings of the $15^{\text {th }}$ IEEE/NPSS Symposium on Fusion Engineering, Hyannis, MA, October 11-15, 1993, IEEE (1994) 1051-1054.

Chiocchio, 2010. S. Chiocchio, B. De Gentile, M. Shute, Project Requirements, version 4.6, ITER IDM 27ZRW8, May 2010, section 7.3.

Ciattaglia, 2012. S. Ciattaglia, G. Cambi, Environmental Conditions Room Book, ITER IDM 2UUZ23, September 12, 2012.

Clark, 2007. E. A. Clark, K. L. Shanahan, "Effects of Tritium on UHMW-PE, PTFE, and Vespel Polyimide," Fusion Science and Technology, 52 (2007) 1007-1011.

Denson, 1996. W. Denson, W. Crowell, P. Jaworski, D. Mahar, Electronic Parts Reliability Data 1997, EPRD-1997, Reliability Analysis Center, Rome, New York, November 1996.

Dexter, 1982. A. H. Dexter and W. C. Perkins, Component Failure-Rate Data with Potential Applicability to a Nuclear Fuel Reprocessing Plant, DP-1633, Savannah River Laboratory, July 1982.

Dey, 1995. M. Dey, L. Skoblar. P. Chen, D. Goldin, P. Cybulskis, L. Minton, S. Rose, W. Roman, Performance-Based Containment Leak-Test Program, NUREG-1493, US Nuclear Regulatory Commission, Appendix C, September 1995.

Drexel, 1996. C. F. Drexel, "Digital Mass Flow Controllers Come of Age," Solid State Technology, volume 39, number 11 (1996) 99-106.

Eide, 1991. S. A. Eide, S. T. Khericha, M. B. Calley, D. A. Johnson, and M. L. Marteeny, Component External Leakage and Rupture Frequency Estimates, EGG-SSRE-9639, Idaho National Engineering Laboratory, November 1991.

Fairfax, 1993. S. A. Fairfax et al., "Operation of the Alcator C-MOD Power System," Proceedings of the $15^{\text {th }}$ IEEE/NPSS Symposium on Fusion Engineering, Hyannis, Massachusetts, October 11-15, 1993, IEEE (1993) p 877-880.

Fields, 2012. W. Fields, J. Reade, D. Mahar, Failure Mode/Mechanism Distributions 2013, FMD-13, Reliability Information Analysis Center, Utica, New York, December 2012.

Finken, 2001. K. H. Finken et al., "Mitigation of disruptions by fast helium gas puffs," Nuclear Fusion, 41 (2001) 1651-1661. 
Fricks, 1998. R. M. Fricks, K. S. Trivedi, “Availability modeling of energy management systems," Microelectronics Reliability, 38 (1998) 727-743.

Gillen, 1990. K. T. Gillen, R. L. Clough, Predictive Aging Results for Cable Materials in Nuclear Power Plants, SAND-90-2009, Sandia National Laboratories, November 1990.

Granetz, 2006. R. Granetz et al., "Gas jet disruption mitigation studies on Alcator C-Mod," Nuclear Fusion, 46 (2006) 1001-1008.

Gray, 1969. P. S. Gray and C. Watts, "Operating Experience with the Dragon Reactor," paper SM-111/66, in Advanced and High-Temperature Gas-Cooled Reactors, IAEA, Vienna, 1969, pages 3-19.

GSSR, 2001. Generic Site Safety Report (GSSR), volume VII, Analysis of Reference Events, ITER document G 84 RI 6 01-07-10 R 1.0, July 2001, page VII-11.

Guyer, 1982. E. C. Guyer, D. L. Brownell, J. G. Bourne, and W. F. Lenz, Control of Containment Air Temperature: An Industry Survey and Insulation Test, EPRI NP-2694, Electric Power Research Institute, October 1982.

Hale, 2001. P. S. Hale, Jr., and R. G. Arno, "Survey of Reliability and Availability Information for Power Distribution, Power Generation, and HVAC Components for Commercial, Industrial, and Utility Installations," ASHRAE Transactions, 107 (2001) 360-389.

Harris, 1984. A. P. Harris, Reliability and Maintainability Data for Industrial Plants, TD-84-3, A. P. Harris \& Associates, Ottawa, Canada, Spring 1984.

Hourtoule, 2005. J. Hourtoule, D. van Houtte, P. Fejoz, P. Hertout, "Magnetic compatibility of standard components for electrical installations, tests on programmable logic controllers and other electronic devices," Fusion Engineering and Design, 75-79 (2005) 179-183.

Hemmerich, 1989. J. L. Hemmerich et al., "Key Components of the JET Active Gas Handling System - Experimental Programme and Test Results," Fusion Engineering and Design, 11 (1989) 93-100.

Hemmerich, 1992. J. L. Hemmerich, R. Lässer, T. Winkel, "Gas recovery system for the first JET tritium experiment," Fusion Engineering and Design, 19 (1992) 161-167.

Hoffman, 1998. D. M. Hoffman, B. Singh, J. H. Thomas III, editors, Handbook of Vacuum Science and Technology, Academic Publishers, San Diego, California (1998), section 3.4.2.

Hubert, 2003. C. I. Hubert, Operating, Testing, and Preventive Maintenance of Electrical Power Apparatus, Prentice Hall Publishers, Upper Saddle River, New Jersey, 2003, section 23.6.

IEC, 2006. Analysis techniques for system reliability-Procedure for failure mode and effects analysis, IEC 60812, second edition, International Electrotechnical Commission, Geneva, Switzerland, 2006. 
Jacobus, 1990. M. J. Jacobus, Aging of Cables, Connections, and Electrical Penetration Assemblies Used in Nuclear Power Plants, NUREG/CR-5461, US Nuclear Regulatory Commission, July 1990, page 29.

Korsah, 2011. K. Korsah, M. Smith, S. Kim, C. Neumeyer, "Options for Shielding Tokamak Cooling Water Electrical Components against High Magnetic Fields, Proceedings of the $24^{\text {th }}$ IEEE/NPSS Symposium on Fusion Engineering, Chicago, Illinois, June 26-30, 2011.

Kruezi, 2009. U. Kruezi et al., "Massive gas injection experiments at JET - performance and characterization of the disruption mitigation valve," Proceedings of the $36^{\text {th }}$ EPS Conference on Plasma Physics, Sofia, Bulgaria, June 29-July 3, 2009, Europhysics Conference Abstracts, 33E (2009) poster P-2.153. Available at: http://epsppd.epfl.ch/Sofia/html/contents.htm.

Lehnen, 2011. M. Lehnen et al., "Disruption mitigation by massive gas injection in JET," Nuclear Fusion, 51 (2011) doi:10.1088/0029-5515/51/12/123010.

Lyttle, 2013. M. S. Lyttle, ITER designer at Oak Ridge National Laboratory, e-mail communication on MGI system design, August 27, 2013.

Mahar, 2011. D. Mahar et al., Nonelectronic Parts Reliability Data 2011, NPRD-2011, vol. 1, page 2-72, Reliability Information Analysis Center, Utica, New York, January 2011.

Maruyama, 2013. S. Maruyama, M. Shute, SRD-18-DM (Disruption Mitigation Systems) from DOORS, ITER IDM BEJQWA, May 3, 2013.

Merrill, 1991. B. J. Merrill and S. C. Jardin, "Coolant Ingress Induced Disruption Calculations for ITER,” Fusion Technology, 19 (1991) 1278-1283.

Murari, 2004. A. Murari, A. Barzon, "Ultra high vacuum properties of some engineering polymers," IEEE Transactions on Dielectrics and Electrical Insulation, 11 (2004) 613619.

NAR, 2004. Nuclear Analysis Report (NAR), ITER IDM 22F2ST, version 2, July 2004, Figure 3.2 .

Paula, 1993. H. M. Paula, "Failure rates for programmable logic controllers," Reliability Engineering and System Safety, 39 (1993) 325-328.

RPrS, 2011. Rapport Préliminaire de Sûreté, ITER IDM 3ZR2NC, version 3, Volume 1, Chapter 13, section 2.4.2, "Disruption and Runaway Electron Mitigation System R\&D," December $12,2011$.

Sonato, 1993. R. Sonato, S. Vittura, and G. Zollino, "Vacuum and gas handling systems integration in the RFX fusion experiment," Journal of Nuclear Materials, 200 (1993) 337342.

Tavlet, 1998. M. Tavlet, A. Fontaine, H. Schönbacher, Compilation of Radiation Damage Test Data, Part II, thermoset and thermoplastic resins, composite materials, $2^{\text {nd }}$ edition, CERN 98-01, May 18, 1998. 
van Houtte, 2009. D. van Houtte, K. Okayama, F. Sagot, ITER RAMI Analysis Program, ITER IDM 28WBXD, July 23, 2009.

Villaran, 1990. M. Villaran, R. Fullwood, M. Subudhi, Aging Assessment of Instrument Air Systems in Nuclear Power Plants, NUREG/CR-5419, US Nuclear Regulatory Commission, January 1990.

Volotinen, 1999. T. Volotinen et al., editors, Reliability of Optical Fibres and Components, Springer Verlag, London, UK, 1999, page 312.

Walker, 2011. I. R. Walker, Reliability in Scientific Research, Cambridge University Press, 2011, section 3.8,

Yang, 2010. Y. Yang, S. Maruyama, R. Pitts, M. Sugihara, W. Li, T. Jiang, B. Li, "System requirements and design challenges of the gas injection system of ITER," Fusion Engineering and Design, 85 (2010) 2292-2294. 


\section{FMEA RESULTS}

This chapter gives an overview of the results of the FMEA pages that are listed in Appendix A. Suggestions to the designers are also given in this chapter under the conclusions and recommendations section.

\subsection{FMEA Results}

The following tables show the results from the FMEA, starting with the major risks (criticality $\geq 13$ ) and then the moderate risks $(8 \geq$ criticality $\geq 12)$. Major risks should be mitigated by either making changes so that the occurrence frequency decreases or the severity of the failure event decreases. Moderate risks are advised to consider mitigation. Minor risks can be tolerated in the existing design and are only listed in the tables in Appendix A.

Table 3-1. List of preliminary FMEA major risks.

\begin{tabular}{|c|c|c|c|}
\hline Component & Failure mode & $\begin{array}{c}\text { Criticality } \\
\mathrm{S} \cdot \mathrm{O}=\mathrm{C}\end{array}$ & Comments \\
\hline Argon-neon compressor & contamination & $4 \times 6=24$ & $\begin{array}{l}\text { Oil and moisture contamination } \\
\text { in gas }\end{array}$ \\
\hline Deuterium compressor & contamination & $4 \times 6=24$ & $\begin{array}{l}\text { Oil and moisture contamination } \\
\text { in gas }\end{array}$ \\
\hline DM-1 valve & Fails to open on demand & $5 \times 4=20$ & $\begin{array}{l}\text { Experience data from tokamaks } \\
\text { is small, so failure rate is high }\end{array}$ \\
\hline DM-1 valve & Fails to reclose & $5 \times 4=20$ & $\begin{array}{l}\text { Experience data from tokamaks } \\
\text { is small, so failure rate is high }\end{array}$ \\
\hline DM-1 valve & Internal leak & $5 \times 3=15$ & $\begin{array}{l}\text { Criticality was driven by the } \\
\text { repair severity. }\end{array}$ \\
\hline $\begin{array}{l}\text { High voltage cable in } \\
\text { port plug }\end{array}$ & Short circuit & $5 \times 3=15$ & $\begin{array}{l}\text { Did not have failure data for } \\
\text { mineral insulated co-ax cable, } \\
\text { used traditional cable data }\end{array}$ \\
\hline $\begin{array}{l}\text { High voltage cable in } \\
\text { port plug }\end{array}$ & Open circuit & $5 \times 3=15$ & $\begin{array}{l}\text { Did not have failure data for } \\
\text { mineral insulated co-ax cable, } \\
\text { used traditional cable data }\end{array}$ \\
\hline
\end{tabular}


Table 3-2. List of preliminary FMEA moderate risks.

\begin{tabular}{|c|c|c|c|}
\hline Component & Failure mode & $\begin{array}{l}\text { Criticality } \\
\mathrm{S} \cdot \mathrm{O}=\mathrm{C}\end{array}$ & Comments \\
\hline $\begin{array}{l}\text { Argon and Neon } \\
\text { compressor and } \\
\text { deuterium compressor }\end{array}$ & Fails to start & $2 \times 5=10$ & $\begin{array}{l}\text { Criticality was driven by failure } \\
\text { rate. When specific } \\
\text { compressors are selected, re- } \\
\text { evaluate the failure rate. }\end{array}$ \\
\hline $\begin{array}{l}\text { Argon and Neon } \\
\text { compressor and } \\
\text { deuterium compressor }\end{array}$ & Fails to stop & $2 \times 5=10$ & See above entry \\
\hline $\begin{array}{l}\text { Gas Valve } 1 \text { through gas } \\
\text { valve } 5\end{array}$ & $\begin{array}{l}\text { Internal leak past the } \\
\text { seat }\end{array}$ & $2 \times 4=8$ & $\begin{array}{l}\text { Criticality was driven by failure } \\
\text { rate. When specific valves are } \\
\text { selected, re-evaluate the failure } \\
\text { rate. }\end{array}$ \\
\hline DM-1 valve & Spurious operation & $2 \times 4=8$ & $\begin{array}{l}\text { Experience data from tokamaks } \\
\text { is small, so failure rate is } \\
\text { somewhat high }\end{array}$ \\
\hline DM-1 valve & Plugging & $2 \times 4=8$ & $\begin{array}{l}\text { Experience data from tokamaks } \\
\text { is small, so failure rate is } \\
\text { somewhat high }\end{array}$ \\
\hline DM-1 valve & Internal rupture & $5 \times 2=10$ & $\begin{array}{l}\text { Criticality was driven by the } \\
\text { repair severity. }\end{array}$ \\
\hline DM-1 valve & External leak & $5 \times 2=10$ & $\begin{array}{l}\text { Criticality was driven by the } \\
\text { repair severity. }\end{array}$ \\
\hline Thyristor & Fails on demand & $2 \times 4=8$ & $\begin{array}{l}\text { Criticality was driven by the } \\
\text { failure rate. More data is } \\
\text { needed on thyristors. }\end{array}$ \\
\hline
\end{tabular}

\subsection{FMEA Conclusions and Recommendations}

There are several issues to discuss in the conclusions and recommendations. Starting with the major risks, there is the possibility of chemical contamination in the gas used in this system. The cleanliness of the gas supplied by the ITER in-plant gas supply system is not known at this time. INL experience is that even research grade gases supplied in cylinders have ppm levels of impurities such as water vapor, air, and organic molecules. The impurity levels are low but can interfere with experiments. In reviewing past operating experiences in the nuclear industry, the Peach Bottom 1 high temperature helium-gas cooled fission reactor had the following impurity levels in its coolant helium during a plant startup following a maintenance outage (Scheffel, 1976): 
$\underline{\text { Constituent }}$

$\mathrm{H}_{2} \mathrm{O}$ vapor

$\mathrm{CO}_{2}$

$\mathrm{O}_{2}$-Argon

$\mathrm{N}_{2}$ gas

$\mathrm{CH}_{4}$

$\mathrm{CO}$
Maximum Concentration in

volume parts per million (vppm)

9

7

1.4

9

2.4

9.9

As the Peach Bottom-1 plant heated up and flowed gas through the cleanup system, after two days the impurity gas levels all dropped to about $2 \mathrm{vppm}$, and the water vapor concentration dropped to $1 \mathrm{vppm}$. These concentrations were acceptable to operate the $115 \mathrm{MW}$ thermal power plant. Presumably, impurity concentrations such as these would be tolerable for the DMS and the ITER vacuum vessel.

The other potentially damaging contaminant is lube oil from the gas compressors. Perhaps diaphragm compressors, that are reputed to be low oil or oil-less, could be used for this system. If not, then some other low oil or oil-less compressors are needed. If low oil units are selected, then a means of oil capture for removal from the gas stream is needed in the design. The oil is detrimental for gas systems, it causes seals to become brittle and to collect impurities (Villaran, 1990). Some of the experience information comes from large industrial air systems that are not highly similar to the DM system. Nonetheless, we have determined that the DM system will operate fairly regularly ( once per operating day) and if the compressors do leak oil it will be a concern. Besides causing seal degradation, oil also has a tendency to clog up filters, mass flow controllers, needle valves, etc. No gas filters were included in the system schematic, but perhaps compressor outlet filters would be included as the design progresses. Filters can pose a trade-off, if filters disintegrate the filter media material is spread around the gas system, tending to foul instruments and valve seats. For the DM system, a portion of any debris is likely to be expelled into the vacuum vessel. However, filters do serve to trap impurities like oil and debris from spreading around the system.

The DM-1 valve from Figure 2-4 did not have any operating experience data since it is a new design. A similar eddy current valve design is in operation at two tokamaks, so experience data from those valves in service was used to infer a failure rate for the new valve design. The operating experience is modest, there have been only a few hundred demands of that small number of valves. The failure rate of 1.66E-03/demand found from data in Table 2-3 is a good failure rate value from one perspective; it is only a factor of 1.44 greater than that of a very wide set of thousands of solenoid valves used for years in industry (see Eide, 2007). Solenoid valves are certainly not the same as the DM-1 eddy current valve, but solenoid valves are somewhat similar and are the closest industrial component having a mature set of reliability data for comparison. The DM-1 valve spurious operation failure rate value of $1 \mathrm{E}-04 / \mathrm{h}$ from Table $2-3$ is a factor of $\sim 1,000$ larger than the analogous failure rate for solenoid valves (see Eide, 2007). As the DMS design progresses, the two tokamaks will continue to operate their eddy current valves and tracking the additional accumulated operating experience will be valuable for obtaining a more accurate DM valve failure rate estimate. The JET and TEXTOR valve data can be combined with any design prototype test data performed for this project.

A high voltage cable in the port plug routes electrical energy to the DM-1 valve coil to open the valve. A cable fault in the port plug would be difficult to repair. Additional work to determine a failure rate for mineral insulated cables rather than traditional cables will be undertaken as the design progresses. Mineral insulated cable is reputed to be radiation resistant, 
for example Saeki (2001) discussed that the conventional polymer insulation for a vacuum gauge cable embrittled and failed at 55 Mrads radiation exposure in service on a particle accelerator, while a Co-60 test of a mineral insulated cable (the leading candidate option to replace the failed cable) showed no cable insulation degradation at 190 Mrads exposure.

A potential safety issue was noted in the FMEA. Use of deuterium gas in this system poses explosion safety concerns. It was noted that if the $\mathrm{D}_{2}$ gas compressor drew in room air through an inlet leak then it might be possible to have a gas combustion event inside the compressor or piping. Perhaps the deuterium pressure would be too high within the compressor to allow air to be drawn in; and there is a design provision that would also preclude air ingress. The FMEA also noted that deuterium gas leaks into the port cell could potentially accumulate to achieve the minimum explosive concentration of $4.9 \%$ deuterium in air. The designers recognized this safety issue and are considering use of a positive pressure nitrogen atmosphere (purged) cask or enclosure to house the $\mathrm{D}_{2}$ compressor and associated equipment, and doublewalled lines with a nitrogen purge in the annulus for the lines that must run outside the enclosure in the port cell (Lyttle, 2013). The preliminary safety report for ITER discusses that the equatorial port cells and upper port cells have no anti-deflagration zone assigned to them because all hydrogen-bearing components that have a vulnerability to leakage of the pipe work are to be doubly confined (RPrS, 2011). Therefore, the designer's double confinement design idea meets the ITER double confinement safety requirements. The FMEA also queried if the port cell would have a hydrogen monitor. The port cell atmospheres are monitored for gamma radiation, tritium beta radiation, radioactive gases, and the atmospheres are sampled for radioactive dust and beryllium dust (RPrS, 2011). However, the port cell room atmospheres are not monitored for hydrogen species due to the double confinement of the protium, deuterium, and tritium isotopes. Double confinement uses guard pipes around process pipes and gloveboxes around valves. The steel gloveboxes maintain a nitrogen atmosphere, use safety glass windows, have glove ports protected by metal covers. The gloveboxes also use oxygen monitors to detect room air leakage into the glovebox and hydrogen monitors to detect any process gas leakage from the valves or pipes into the glovebox. The hydrogen specie gas lines are all-welded stainless steel (no flanged or screwed connections), and are surrounded by a guard pipe. The guard pipe annulus is operated at below atmospheric pressure. The guard pipe annulus is pumped down by the rough vacuum system (RPrS, 2011). It should be noted that when using additional safety barriers such as guard pipes and equipment enclosures, the maintenance time increases due to barrier entry (e.g., removing hatches or panels for ingress and establishing a safe atmosphere gas to allow maintenance work to proceed), then there is the additional time to reseal and test barrier integrity and re-establish a nitrogen atmosphere. The barriers themselves can require maintenance (replacing seals, painting, decontamination, etc.), and finally there is periodic inspection time for the barrier as well. These safety design provisions can be addressed in the future.

The scope of work was to perform a design support FMEA on this conceptual system. No reliability block diagram or fault tree was constructed of the system. Quantitatively, the reliability of the TM system to fire once on demand is estimated by the sum of the demand failure rates for 1 demand. An assumption is made that the system is fully and adequately prepared and is waiting for an actuation signal. Details of the trigger circuit power supply operating on demand are not known at this time, so the components that must function on demand are the set of DM-1 valves and the set of thyristors. $R=1-[(4$ thyristors $)(3.125 \mathrm{E}-04 /$ unit-demand $)(1 \mathrm{~d})+$ (4 valves)(1.66E-03/unit-demand)( $1 \mathrm{~d})]$ or $\mathrm{R}=1-0.00789$. Then $\mathrm{R}=0.99211$. The "one demand" reliability for the system is $99.2 \%$.

Despite this $99 \%$ reliability for actuating the system, it is noted that this system is a single-path, series-component system; that is, there are no redundant components shown in the 
schematics in Figures 2-1 and 2-3. From experience with other systems, the triggering electronic system is overall a simple, functional system with generally low failure rate items. In reliability, simpler is better and redundancy is used sparingly since it incurs costs in plant floor space, component capital cost, maintenance and testing cost, etc. The FMEA revealed is that the system components all have several failure modes, and any one component failure is likely to prevent the system from operating since there is no redundancy in this system. Perhaps the redundancy issue will be addressed by the system success criteria, if - for example - only 3 of 4 TM valves are needed to function when actuated, then a random fault in one circuit or gas supply would be tolerable.

There are some reliability issues to address in design. One issue is the actuation signal. This was not described in the system design description. Perhaps the actuation signal is already well planned. In protective systems such as this one, some sort of voting logic (perhaps 2 out of 3 signals agreeing) is needed. Perhaps the signal from plasma diagnostics into the central control system will already have voting logic applied, otherwise the MGI DM system could receive unnecessary signals to actuate from one diagnostic device, leading to gas injection to the edge of a plasma that was healthy enough to not require disruption mitigation. Another concern is consideration of how the DM system responds to ITER off-normal events. The ITER vessel and wall modules are water-cooled, and early estimates of water leaks into the vacuum vessel were assumed to be yearly. The response of the DM valves that have an open path to the vessel must be investigated for steam and pressure. Preliminary literature searches for vespel polyimide compatibility with steam uncovered no data. More exhaustive searches should be performed. If these searches do not produce any data, then the suggestion is that the vespel be tested in a steam environment likely to be found in the ITER vessel, $\sim 120^{\circ} \mathrm{C}$ or greater, up to $0.2 \mathrm{MPa}$.

This conceptual design shows promise to meet ITER needs. 


\subsection{References}

Eide, 2007. S. A. Eide et al., Industry-Average Performance for Components and Initiating Events at U.S. Commercial Nuclear Power Plants, NUREG/CR-6928, US Nuclear Regulatory Commission, February 2007, appendix A.

Lyttle, 2013. M. S. Lyttle, ITER designer at Oak Ridge National Laboratory, e-mail communication on deuterium safety design, October 1, 2013.

RPrS, 2011. Rapport Préliminaire de Sûreté, ITER IDM 3ZR2NC, version 3, December 12, 2011. Sections: vol I, Ch 9.3, p.10/41; vol I, Ch. 6.4.5, p.17/22; Vol II, Ch. 3.1, p.22/140 and Vol II, Ch. 3.1, p.91/140.

Saeki, 2001. H. Saeki, T. Aoki, T. Momose, "Mineral insulated gauge cable irradiated in the Spring-8 storage ring," Journal of Vacuum Science and Technology A, 19 (2001) 10221023.

Scheffel, 1976. W. J. Scheffel et al., Operating History Report for the Peach Bottom HTGR, Volume 1, reactor operating history, GA-A13907, General Atomic Company, August 31, 1976.

Villaran, 1990. M. Villaran, R. Fullwood, M. Subudhi, Aging Assessment of Instrument Air Systems in Nuclear Power Plants, NUREG/CR-5419, US Nuclear Regulatory

Commission, January 1990. 


\section{Appendix A \\ Preliminary Failure Modes and Effects Analysis for the MGI DM System}




\begin{tabular}{|c|c|c|c|c|c|c|c|c|c|c|c|}
\hline Component & $\begin{array}{c}\begin{array}{c}\text { Operational } \\
\text { State }\end{array} \\
\end{array}$ & Failure Mode & Possible Causes & $\begin{array}{c}\text { Preventive Action } \\
\text { on Possible Causes }\end{array}$ & Consequences & $\begin{array}{c}\text { Corrective or } \\
\text { Preventive Actions on } \\
\text { Consequences }\end{array}$ & Comments & $\begin{array}{l}\text { Failure } \\
\text { rate }\end{array}$ & \begin{tabular}{|c|c|}
$\begin{array}{c}\text { Comment } \\
\text { on failure } \\
\text { rate }\end{array}$ \\
\end{tabular} & $\begin{array}{c}\text { Criticality } \\
\text { Number } \\
\mathrm{S} \cdot \mathrm{O}=\mathrm{C}\end{array}$ & Design comments \\
\hline \multirow[t]{9}{*}{$\begin{array}{l}\text { Argon and Neon } \\
\text { compressor, Comp- } 1\end{array}$} & $\begin{array}{l}\text { Normally } \\
\text { shutdown } \\
\text { during DM } \\
\text { system } \\
\text { operation }\end{array}$ & Fails to start & $\begin{array}{l}\text { Electronics fault in } \\
\text { control circuitry, } \\
\text { software error, loss } \\
\text { of power, human } \\
\text { error, mechanical } \\
\text { fault }\end{array}$ & $\begin{array}{l}\text { Regular test, } \\
\text { regular inspection, } \\
\text { software QA, } \\
\text { diverse power } \\
\text { supplies, detailed } \\
\text { operating } \\
\text { procedures }\end{array}$ & $\begin{array}{l}\text { Cannot charge the MGI DM } \\
\text { valves with appropriate gas } \\
\text { mixture, so no investment } \\
\text { protection for the vacuum } \\
\text { vessel. ITER outage until } \\
\text { repaired. }\end{array}$ & $\begin{array}{l}\text { Repair compressor to } \\
\text { regain system } \\
\text { operability and ITER } \\
\text { operability }\end{array}$ & $\begin{array}{l}\text { Hale (2001) gives some repair } \\
\text { times. Compressor MTTR }<10 \\
\text { h. Thus, } S=2\end{array}$ & $\begin{array}{l}6.25 \mathrm{E}-03 / \mathrm{d} \\
\text { and } \\
200 \mathrm{~d} / \mathrm{y} \\
\mathrm{O}=5\end{array}$ & $\begin{array}{l}\text { Blanchard } \\
1998, \\
\text { Table } 2-4 \mathrm{k} \\
\text { factor of } \\
1.25 .\end{array}$ & $2 \times 5=10$ & \\
\hline & & Fails to run & $\begin{array}{l}\text { Electronics fault in } \\
\text { control circuitry, } \\
\text { software error, loss } \\
\text { of power, human } \\
\text { error, mechanical } \\
\text { fault }\end{array}$ & $\begin{array}{l}\text { Regular test, } \\
\text { regular inspection, } \\
\text { software QA, } \\
\text { diverse power } \\
\text { supplies, detailed } \\
\text { operating } \\
\text { procedures }\end{array}$ & $\begin{array}{l}\text { Cannot charge the MGI DM } \\
\text { valves with appropriate gas } \\
\text { mixture, so no investment } \\
\text { protection for the vacuum } \\
\text { vessel. ITER outage until } \\
\text { repaired. }\end{array}$ & $\begin{array}{l}\text { Repair compressor to } \\
\text { regain system } \\
\text { operability and ITER } \\
\text { operability }\end{array}$ & $\begin{array}{l}\text { Hale (2001) gives some repair } \\
\text { times. Compressors }<10 \mathrm{~h} \text { for } \\
\text { MTTR. Thus, } \mathrm{S}=2\end{array}$ & $\begin{array}{l}6.25 \mathrm{E}-05 / \mathrm{h} \\
\text { and } \\
200 \mathrm{~d} / \mathrm{y} \\
\text { and } 3 \mathrm{~h} / \mathrm{d} \\
\mathrm{O}=3\end{array}$ & $\begin{array}{l}\text { Blanchard } \\
1998, \\
\text { Table } 2-4 \mathrm{k} \\
\text { factor of } \\
1.25 .\end{array}$ & $2 \times 3=6$ & \\
\hline & & Overspeed & $\begin{array}{l}\text { Electronics fault in } \\
\text { control circuitry, } \\
\text { software error }\end{array}$ & $\begin{array}{l}\text { Regular test, and } \\
\text { software QA }\end{array}$ & $\begin{array}{l}\text { Overpressurize the gases, the } \\
\text { system should compensate } \\
\text { back to correct pressure }\end{array}$ & $\begin{array}{l}\text { No immediate repair } \\
\text { needed, but should } \\
\text { investigate at first } \\
\text { opportunity }\end{array}$ & $\begin{array}{l}\text { Hale (2001) gives some repair } \\
\text { times. Compressors }<10 \mathrm{~h} \text { for } \\
\text { MTTR. Thus, } \mathrm{S}=2\end{array}$ & $\begin{array}{l}1.25 \mathrm{E}-05 / \mathrm{h} \\
\text { and } \\
200 \mathrm{~d} / \mathrm{y} \\
\text { and } 3 \mathrm{~h} / \mathrm{d} \\
\mathrm{O}=3\end{array}$ & $\begin{array}{l}\text { Blanchard } \\
1998, \\
\text { Table 2-4 } \mathrm{k} \\
\text { factor of } \\
1.25 .\end{array}$ & $2 \times 3=6$ & \\
\hline & & Underspeed & $\begin{array}{l}\text { Electronics fault in } \\
\text { control circuitry, } \\
\text { software error }\end{array}$ & $\begin{array}{l}\text { Regular test, and } \\
\text { software QA }\end{array}$ & Underpressurizes the gases & $\begin{array}{l}\text { Repair compressor to } \\
\text { regain system } \\
\text { operability and ITER } \\
\text { operability }\end{array}$ & $\begin{array}{l}\text { Hale (2001) gives some repair } \\
\text { times. Compressors }<10 \mathrm{~h} \text { for } \\
\text { MTTR. Thus, } S=2\end{array}$ & $\begin{array}{l}1.25 \mathrm{E}-05 / \mathrm{h} \\
\text { and } \\
200 \mathrm{~d} / \mathrm{y} \\
\text { and } 3 \mathrm{~h} / \mathrm{d} \\
\mathrm{O}=3\end{array}$ & $\begin{array}{l}\text { Assumed from } \\
\text { Blanchard } \\
1998 \text {, Table 2- } \\
4 \mathrm{k} \text { factor of } \\
1.25 .\end{array}$ & $2 \times 3=6$ & \\
\hline & & Fails to stop & $\begin{array}{l}\text { Electronics fault in } \\
\text { control circuitry, } \\
\text { software error }\end{array}$ & $\begin{array}{l}\text { Regular test, and } \\
\text { software QA }\end{array}$ & $\begin{array}{l}\text { Overpressurize the gases, the } \\
\text { system should compensate } \\
\text { back to correct pressure }\end{array}$ & $\begin{array}{l}\text { Operator can depower } \\
\text { compressor from a } \\
\text { motor control center or } \\
\text { panel }\end{array}$ & $\begin{array}{l}\text { Hale (2001) gives some repair } \\
\text { times. Compressors }<10 \mathrm{~h} \text { for } \\
\text { MTTR. Thus, } \mathrm{S}=2\end{array}$ & $\begin{array}{l}5 \mathrm{E}-03 / \mathrm{d} \\
\text { and } \\
200 \mathrm{~d} / \mathrm{y} \\
\mathrm{O}=5\end{array}$ & $\begin{array}{l}\text { Blanchard } \\
1998, \\
\text { Table 2-4 } \mathrm{k} \\
\text { factor of } \\
1.25 . \\
\end{array}$ & $2 \times 5=10$ & \\
\hline & & $\begin{array}{l}\text { Leakage at } \\
\text { outlet side }\end{array}$ & $\begin{array}{l}\text { Shaft seal fault, } \\
\text { small crack }\end{array}$ & $\begin{array}{l}\text { Regular test and } \\
\text { inspection }\end{array}$ & Lose system pressure. & $\begin{array}{l}\text { Cannot reach specified } \\
\text { gas pressure for DM } \\
\text { valve }\end{array}$ & $\begin{array}{l}\text { Hale (2001) gives some repair } \\
\text { times. Compressors }<10 \mathrm{~h} \text { for } \\
\text { MTTR. Thus, } \mathrm{S}=2\end{array}$ & $\begin{array}{l}3 \mathrm{E}-07 / \mathrm{h} \\
200 \mathrm{~d} / \mathrm{y} \\
\text { and } 3 \mathrm{~h} / \mathrm{d} \\
\mathrm{O}=1\end{array}$ & $\begin{array}{l}\text { Blanchard } \\
1998, \text { no k } \\
\text { factor } \\
\text { needed }\end{array}$ & $2 \times 1=2$ & \\
\hline & & $\begin{array}{l}\text { Leakage at } \\
\text { inlet side }\end{array}$ & $\begin{array}{l}\text { Shaft seal fault, } \\
\text { small crack }\end{array}$ & $\begin{array}{l}\text { Regular test and } \\
\text { inspection }\end{array}$ & $\begin{array}{l}\text { Compressor could draw } \\
\text { room air into gas stream or } \\
\text { leak gas, depending on the } \\
\text { gas inlet pressure. }\end{array}$ & Contaminated gas & $\begin{array}{l}\text { Air contamination will decrease } \\
\text { system effectiveness. Hale } \\
\text { (2001) gives some repair times. } \\
\text { Compressors }<10 \text { h for MTTR. } \\
\text { Thus, } S=2\end{array}$ & $\begin{array}{l}3 \mathrm{E}-07 / \mathrm{h} \\
200 \mathrm{~d} / \mathrm{y} \\
\text { and } 3 \mathrm{~h} / \mathrm{d} \\
\mathrm{O}=1\end{array}$ & $\begin{array}{l}\text { Blanchard } \\
1998, \text { no k } \\
\text { factor } \\
\text { needed }\end{array}$ & $2 \times 1=2$ & $\begin{array}{l}\text { Not easy to detect that air is drawn } \\
\text { in to the compressor, probably by } \\
\text { gas sampling. }\end{array}$ \\
\hline & & $\begin{array}{l}\text { Rupture of } \\
\text { compressor } \\
\text { body }\end{array}$ & $\begin{array}{l}\text { Shaft seal failure, } \\
\text { catastrophic crack }\end{array}$ & $\begin{array}{l}\text { Regular test and } \\
\text { inspection }\end{array}$ & Lose outlet gas pressure. & $\begin{array}{l}\text { Repair or replace } \\
\text { compressor to regain } \\
\text { system operability and } \\
\text { ITER operability }\end{array}$ & $\begin{array}{l}\text { Rupture assumed to require } \\
\text { replacement. Assume }<1 \text { week. } \\
\text { Thus } S=3\end{array}$ & $\begin{array}{l}1 \mathrm{E}-08 / \mathrm{h} \\
200 \mathrm{~d} / \mathrm{y} \\
\text { and } 3 \mathrm{~h} / \mathrm{d} \\
\mathrm{O}=1\end{array}$ & $\begin{array}{l}\text { Blanchard } \\
1998, \text { no k } \\
\text { factor } \\
\text { needed }\end{array}$ & $3 \times 1=3$ & $\begin{array}{l}\text { Expected design IAW ASME } \\
\text { B31.3, sect } 301.2 .2 \text { - pressure } \\
\text { relief device after compressor. }\end{array}$ \\
\hline & & $\begin{array}{l}\text { Contam- } \\
\text { ination }\end{array}$ & $\begin{array}{l}\text { Lube oil leaks by } \\
\text { seals into gas }\end{array}$ & $\begin{array}{l}\text { Compressor } \\
\text { selection to } \\
\text { preclude lube oil } \\
\text { intrusion issue }\end{array}$ & $\begin{array}{l}\text { Gas is contaminated with oil, } \\
\text { oil enters vacuum vessel, } \\
\text { degrades vacuum. }\end{array}$ & $\begin{array}{l}\text { Select oil-less } \\
\text { compressor, or use } \\
\text { filters on compressor } \\
\text { outlet }\end{array}$ & $\begin{array}{l}\text { Oil often contaminates the gas in } \\
\text { the compressor. Oil molecules } \\
\text { become irradiated close to the } \\
\text { tokamak, oil plugs filters, } \\
\text { embrittles seals, fouls valves. } \\
\text { Difficult repair, assume } S=4\end{array}$ & $\begin{array}{l}\mathrm{I} / \mathrm{h} \\
\mathrm{O}=6\end{array}$ & $\begin{array}{l}\text { Analyst } \\
\text { judgment, } \\
\text { no k factor } \\
\text { needed }\end{array}$ & $4 \times 6=24$ & $\begin{array}{l}\text { Assume a low oil or oil-less type of } \\
\text { compressor is selected, perhaps a } \\
\text { diaphragm compressor. Filters were } \\
\text { not specified on the compressor inlet } \\
\text { or outlet. Filters are recommended } \\
\text { (Walker, 2011, p. } 96-97), \text { but filters } \\
\text { can become plugged. Not easy to } \\
\text { detect oil in process gas, periodic } \\
\text { sampling should be done. }\end{array}$ \\
\hline
\end{tabular}




\begin{tabular}{|c|c|c|c|c|c|c|c|c|c|c|c|}
\hline Component & $\begin{array}{l}\text { Operational } \\
\text { State }\end{array}$ & Failure Mode & Possible Causes & $\begin{array}{l}\text { Preventive Action } \\
\text { on Possible Causes }\end{array}$ & Consequences & $\begin{array}{c}\text { Corrective or } \\
\text { Preventive Actions on } \\
\text { Consequences }\end{array}$ & Comments & $\begin{array}{l}\text { Failure } \\
\text { rate }\end{array}$ & $\begin{array}{c}\text { Comment } \\
\text { on failure } \\
\text { rate }\end{array}$ & $\begin{array}{c}\text { Criticality } \\
\text { Number } \\
\mathbf{S} \cdot \mathbf{O}=\mathrm{C}\end{array}$ & Design comments \\
\hline \multirow[t]{3}{*}{$\begin{array}{l}\text { Pressure regulator } \\
\text { for argon and neon, } \\
\text { Reg-1 }\end{array}$} & $\begin{array}{l}\text { Normally } \\
\text { operating }\end{array}$ & $\begin{array}{l}\text { Fail to } \\
\text { regulate } \\
\text { pressure to } \\
\text { DM valve } \\
\text { closure } \\
\text { volume } \\
\end{array}$ & $\begin{array}{l}\text { Wear or fouling of } \\
\text { poppet or seal in } \\
\text { regulator allows } \\
\text { pressure increase }\end{array}$ & $\begin{array}{l}\text { Regular test and } \\
\text { inspection, regular } \\
\text { maintenance }\end{array}$ & $\begin{array}{l}\text { Gas pressure high out of } \\
\text { specifications delivered to } \\
\text { the DM valve closure } \\
\text { volume. Valve does not } \\
\text { perform up to spec. }\end{array}$ & $\begin{array}{l}\text { Pressure monitoring will } \\
\text { alert operators to system } \\
\text { being out of } \\
\text { specification }\end{array}$ & $\begin{array}{l}\text { Reported value is for all failure } \\
\text { modes. Assume repair is }<8 \mathrm{~h} \text {, } \\
\text { so } S=2\end{array}$ & $\begin{array}{l}9.6 \mathrm{E}-08 / \mathrm{h} \\
200 \mathrm{~d} / \mathrm{y} \\
3 \mathrm{~h} / \mathrm{d} \\
\mathrm{O}=1\end{array}$ & $\begin{array}{l}\text { Hale } 2001 \\
\text { no k factor } \\
\text { assumed }\end{array}$ & $2 \times 1=2$ & $\begin{array}{l}\text { Air Liquide (2010) states } \\
\text { diaphragm in regulator dries out } \\
\text { when using very dry gas, so check } \\
\text { monthly, replace more often than } \\
\text { each } 10 \text { years. }\end{array}$ \\
\hline & & Fails closed & $\begin{array}{l}\text { Spring relaxation } \\
\text { or fracture, } \\
\text { diaphragm failure }\end{array}$ & $\begin{array}{l}\text { Regular test and } \\
\text { inspection, regular } \\
\text { maintenance }\end{array}$ & $\begin{array}{l}\text { No gas delivered through } \\
\text { regulator }\end{array}$ & $\begin{array}{l}\text { Repair regulator to } \\
\text { regain system } \\
\text { operability and ITER } \\
\text { operability }\end{array}$ & $\begin{array}{l}\text { Assumed that a spring failure } \\
\text { rate covers this failure mode. } \\
\text { Assume repair is }<8 \text { h, so } S=2\end{array}$ & $\begin{array}{l}1 \mathrm{E}-06 / \mathrm{h} \\
200 \mathrm{~d} / \mathrm{y}, \\
3 \mathrm{~h} / \mathrm{d} \\
\mathrm{O}=2\end{array}$ & $\begin{array}{l}\text { Dexter } \\
\text { 1982, no k } \\
\text { factor } \\
\text { assumed }\end{array}$ & $2 \times 2=4$ & \\
\hline & & $\begin{array}{l}\text { Leak across } \\
\text { diaphragm }\end{array}$ & Gas diffusion & $\begin{array}{l}\text { Specify diaphragm } \\
\text { for low loss }\end{array}$ & Gas leaks out of regulator & $\begin{array}{l}\text { Monitor Ar, Ne in port } \\
\text { cell, routine ventilation } \\
\text { of port cell }\end{array}$ & $\begin{array}{l}\text { Reported value is for all failure } \\
\text { modes. Assume repair is }<8 \mathrm{~h} \text {, } \\
\text { so } \mathrm{S}=2\end{array}$ & $\begin{array}{l}9.6 \mathrm{E}-08 / \mathrm{h} \\
3000 \mathrm{~h} / \mathrm{y} \\
\mathrm{O}=1\end{array}$ & $\begin{array}{l}\text { Hale } 2001, \\
\text { no } \mathrm{k} \text { factor } \\
\text { assumed }\end{array}$ & $2 \times 1=2$ & $\begin{array}{l}\text { Gas leak into port cell may not be } \\
\text { easy to detect. Oxygen monitor? }\end{array}$ \\
\hline \multirow[t]{6}{*}{$\begin{array}{l}\text { Gas valve near } \\
\text { regulator, Valve-1 } \\
\text { (assume motor } \\
\text { operated valve) }\end{array}$} & $\begin{array}{l}\text { Normally } \\
\text { open }\end{array}$ & $\begin{array}{l}\text { Spurious } \\
\text { operation }\end{array}$ & $\begin{array}{l}\text { Command fault, } \\
\text { human error, } \\
\text { electronic noise }\end{array}$ & $\begin{array}{l}\text { Periodic testing, } \\
\text { software QA }\end{array}$ & $\begin{array}{l}\text { Valve closes, isolates gas } \\
\text { supply. Cannot recharge } \\
\text { that DM valve closure } \\
\text { volume. ITER outage to } \\
\text { repair. }\end{array}$ & $\begin{array}{l}\text { Repair valve to regain } \\
\text { system operability }\end{array}$ & $\begin{array}{l}\text { Perhaps there are success criteria } \\
\text { on how many DM valves can be } \\
\text { failed and still allow ITER to } \\
\text { operate. Hale } 2001, \text { MTTR }=8 \mathrm{~h} \text {, } \\
\text { so } \mathrm{S}=2\end{array}$ & $\begin{array}{l}6.18 \mathrm{E}-07 / \mathrm{h} \\
3000 \mathrm{~h} / \mathrm{y} \\
\mathrm{O}=2\end{array}$ & $\begin{array}{l}\text { Blanchard } \\
1998, \\
\text { Table 2-4 k } \\
\text { factor of } \\
2.06 \\
\end{array}$ & $2 \times 2=4$ & $\begin{array}{l}\text { Must better define success criteria } \\
\text { of the MGI DM system, perhaps } \\
\text { one of } 4 \text { TM valves can be down. }\end{array}$ \\
\hline & & Plugging & $\begin{array}{l}\text { Moisture in system } \\
\text { creates rust that } \\
\text { fouls valve, foreign } \\
\text { material in system } \\
\text { such as hydro- } \\
\text { carbons gum up } \\
\text { valve disk and seat }\end{array}$ & $\begin{array}{l}\text { Regular sampling } \\
\text { of gas in system for } \\
\text { impurities and } \\
\text { foreign materials, } \\
\text { monitor moisture in } \\
\text { system }\end{array}$ & $\begin{array}{l}\text { Cannot charge the MGI DM } \\
\text { valve closure volume with } \\
\text { appropriate gas pressure, so } \\
\text { no machine protection for } \\
\text { the vacuum vessel. ITER } \\
\text { outage until repaired. }\end{array}$ & $\begin{array}{l}\text { Repair valve to regain } \\
\text { system operability. }\end{array}$ & $\begin{array}{l}\text { Cleaning gas piping is a difficult } \\
\text { repair, assume } S=3\end{array}$ & $\begin{array}{l}5 \mathrm{E}-07 / \mathrm{h} \\
\text { and } \\
3000 \mathrm{~h} / \mathrm{y} \\
\mathrm{O}=2\end{array}$ & $\begin{array}{l}\text { Blanchard } \\
1998, \text { no } \mathrm{k} \\
\text { factor } \\
\text { assigned }\end{array}$ & $3 \times 2=6$ & $\begin{array}{l}\text { The DM valve could be damaged } \\
\text { by operation with no gas cushion } \\
\text { in the closure volume. } \\
\text { The cleaning task would be to } \\
\text { flush piping with cleaning agent, } \\
\text { keeping moisture out of piping. }\end{array}$ \\
\hline & & $\begin{array}{l}\text { Internal leak } \\
\text { past seat }\end{array}$ & $\begin{array}{l}\text { Seat wear, not } \\
\text { fully seated by } \\
\text { valve operator }\end{array}$ & $\begin{array}{l}\text { Regular sampling } \\
\text { of gas in system for } \\
\text { foreign materials, } \\
\text { check motor current }\end{array}$ & $\begin{array}{l}\text { Minor problem for small } \\
\text { leak. Can operate the } \\
\text { system. }\end{array}$ & $\begin{array}{l}\text { Repair valve next } \\
\text { outage. }\end{array}$ & Hale $2001, \mathrm{MTTR}=8 \mathrm{~h}$, so $\mathrm{S}=2$ & $\begin{array}{l}1 \mathrm{E}-05 / \mathrm{h} \\
3000 \mathrm{~h} / \mathrm{y} \\
\mathrm{O}=4\end{array}$ & $\begin{array}{l}\text { Blanchard } \\
1998, \text { no k } \\
\text { factor } \\
\text { assigned }\end{array}$ & $2 \times 4=8$ & $\begin{array}{l}\text { Leak past the seat is difficult to } \\
\text { detect. }\end{array}$ \\
\hline & & $\begin{array}{l}\text { Internal } \\
\text { rupture }\end{array}$ & $\begin{array}{l}\text { Valve disk failure, } \\
\text { seat mechanical } \\
\text { failure }\end{array}$ & High QA on valve & $\begin{array}{l}\text { Loss of control of gas flow. } \\
\text { Valve-2 can provide system } \\
\text { operation. }\end{array}$ & $\begin{array}{l}\text { Repair valve next } \\
\text { outage. }\end{array}$ & $\begin{array}{l}\text { Replacing a valve disk and } \\
\text { returning the system to service, } \\
\text { judgment is } S=2\end{array}$ & $\begin{array}{l}5 \mathrm{E}-07 / \mathrm{h} \\
3000 \mathrm{~h} / \mathrm{y} \\
\mathrm{O}=2\end{array}$ & $\begin{array}{l}\text { Blanchard } \\
1998, \text { no k } \\
\text { factor } \\
\text { assigned }\end{array}$ & $2 \times 2=4$ & \\
\hline & & External leak & $\begin{array}{l}\text { Stem seal } \\
\text { degradation, valve } \\
\text { body crack }\end{array}$ & $\begin{array}{l}\text { High QA on valve, } \\
\text { periodic inspection } \\
\text { of stem seal }\end{array}$ & $\begin{array}{l}\text { Wasting gas from the ITER } \\
\text { gas supply. System can } \\
\text { operate with a small leak. }\end{array}$ & $\begin{array}{l}\text { Repair valve next } \\
\text { outage. }\end{array}$ & $\begin{array}{l}\text { Replacing a valve and returning } \\
\text { the system to service, judgment } \\
\text { is } S=3\end{array}$ & $\begin{array}{l}1 \mathrm{E}-07 / \mathrm{h} \\
3000 \mathrm{~h} / \mathrm{y} \\
\mathrm{O}=2\end{array}$ & $\begin{array}{l}\text { Blanchard } \\
1998, \text { no } \mathrm{k} \\
\text { factor } \\
\text { assigned }\end{array}$ & $3 \times 2=6$ & $\begin{array}{l}\text { Gas leak into port cell may not be } \\
\text { easy to detect. }\end{array}$ \\
\hline & & $\begin{array}{l}\text { External } \\
\text { rupture }\end{array}$ & $\begin{array}{l}\text { Stem seal failure, } \\
\text { valve body failure }\end{array}$ & $\begin{array}{l}\text { High QA on valve, } \\
\text { periodic inspection } \\
\text { of stem seal }\end{array}$ & $\begin{array}{l}\text { Cannot charge DM valve } \\
\text { closure volume, ITER } \\
\text { outage until repaired. }\end{array}$ & $\begin{array}{l}\text { Repair valve to regain } \\
\text { system operability. }\end{array}$ & $\begin{array}{l}\text { Replacing a valve and returning } \\
\text { the system to service, judgment } \\
\text { is } S=3\end{array}$ & $\begin{array}{l}5 \mathrm{E}-09 / \mathrm{h} \\
3000 \mathrm{~h} / \mathrm{y} \\
\mathrm{O}=1\end{array}$ & $\begin{array}{l}\text { Blanchard } \\
1998, \text { no k } \\
\text { factor } \\
\text { assigned }\end{array}$ & $3 \times 1=3$ & $\begin{array}{l}\text { Not clear if DM valve would be } \\
\text { damaged by no pressure in the } \\
\text { closure volume. }\end{array}$ \\
\hline \multirow[t]{2}{*}{$\begin{array}{l}\text { Pressure sensor in } \\
\text { Argon-Neon line, } \\
\text { PS-1 }\end{array}$} & $\begin{array}{l}\text { Normally } \\
\text { operating }\end{array}$ & $\begin{array}{l}\text { Fails to } \\
\text { operate }\end{array}$ & $\begin{array}{l}\text { Open circuit, short } \\
\text { circuit }\end{array}$ & $\begin{array}{l}\text { High QA on sensor, } \\
\text { periodic test }\end{array}$ & $\begin{array}{l}\text { Cannot charge DM valve } \\
\text { closure volume to spec, DM } \\
\text { valve will not operate } \\
\text { correctly, but will open. }\end{array}$ & $\begin{array}{l}\text { Repair sensor next } \\
\text { outage. }\end{array}$ & $\begin{array}{l}\text { Hale 2001, Pressure control } \\
\text { MTTR=5.6 h, S=2 }\end{array}$ & $\begin{array}{l}1.25 \mathrm{E}-06 / \mathrm{h} \\
3000 \mathrm{~h} / \mathrm{y} \\
\mathrm{O}=2\end{array}$ & $\begin{array}{l}\text { Cadwallader } \\
1996, \\
\text { Table 2-4 } \mathrm{k} \\
\text { factor of } \\
1.25 . \\
\end{array}$ & $2 \times 2=4$ & $\begin{array}{l}\text { Failed pressure sensor will be } \\
\text { obvious. Many designers have } \\
\text { noted they would have put } \\
\text { redundant sensors into design. Or, } \\
\text { resilient sensors (Beck, 2011). }\end{array}$ \\
\hline & & $\begin{array}{l}\text { Erratic } \\
\text { reading }\end{array}$ & $\begin{array}{l}\text { EM interference, } \\
\text { foreign material } \\
\text { buildup in unit }\end{array}$ & $\begin{array}{l}\text { Shield for EM } \\
\text { energy, specify } \\
\text { clean gas in system }\end{array}$ & $\begin{array}{l}\text { Cannot charge DM valve } \\
\text { closure volume to spec, } \\
\text { valve will not operate } \\
\text { correctly, but will open. }\end{array}$ & $\begin{array}{l}\text { Repair sensor next } \\
\text { outage. }\end{array}$ & $\begin{array}{l}\text { Assume } 50 \% \text { of the failure to } \\
\text { operate failure rate, so } 5 \mathrm{E}-07 / \mathrm{h} \text {, } \\
\text { Table } 2-4 \mathrm{k} \text { factor of } 1.25 \text { gives } \\
6.25 \mathrm{E}-07 / \mathrm{h} \text {. From Hale } 2001 \text {, } \\
\text { Pressure control MTTR }=5.6 \mathrm{~h} \text {, } \\
\mathrm{S}=2\end{array}$ & $\begin{array}{l}6.25 \mathrm{E}-07 \mathrm{~h} / \mathrm{h} \\
3000 \mathrm{~h} / \mathrm{y} \\
\mathrm{O}=2\end{array}$ & $\begin{array}{l}\text { Analyst } \\
\text { judgment }\end{array}$ & $2 \times 2=4$ & \\
\hline
\end{tabular}




\begin{tabular}{|c|c|c|c|c|c|c|c|c|c|c|c|}
\hline Component & $\begin{array}{c}\text { Operational } \\
\text { State }\end{array}$ & Failure Mode & Possible Causes & $\begin{array}{l}\text { Preventive Action } \\
\text { on Possible Causes }\end{array}$ & Consequences & $\begin{array}{c}\text { Corrective or } \\
\text { Preventive Actions on } \\
\text { Consequences }\end{array}$ & Comments & $\begin{array}{c}\text { Failure } \\
\text { rate }\end{array}$ & $\begin{array}{c}\text { Comment } \\
\text { on failure } \\
\text { rate }\end{array}$ & $\begin{array}{c}\text { Criticality } \\
\text { Number } \\
\mathrm{S} \cdot \mathbf{O}=\mathbf{C}\end{array}$ & Design comments \\
\hline \multirow[t]{2}{*}{ PS-1, continued } & $\begin{array}{l}\text { Normally } \\
\text { operating }\end{array}$ & External leak & $\begin{array}{l}\text { Fitting fault or } \\
\text { crack, sensing line } \\
\text { fault }\end{array}$ & $\begin{array}{l}\text { High QA on parts, } \\
\text { installation. } \\
\text { Periodic inspection }\end{array}$ & $\begin{array}{l}\text { Small leak is wasting gas } \\
\text { from the ITER gas supply. }\end{array}$ & $\begin{array}{l}\text { Repair sensor next } \\
\text { outage. }\end{array}$ & $\begin{array}{l}\text { Assume 1-m sensing line. } \\
\text { Hale 2001, Pressure control } \\
\text { MTTR=5.6 h, S=2 }\end{array}$ & $\begin{array}{l}1 \mathrm{E}-07 / \mathrm{h} \\
3000 \mathrm{~h} / \mathrm{y} \\
\mathrm{O}=2\end{array}$ & $\begin{array}{l}\text { Blanchard } \\
1998, \text { no k } \\
\text { factor }\end{array}$ & $2 \times 2=4$ & $\begin{array}{l}\text { Gas leak into port cell may not be } \\
\text { easy to detect. }\end{array}$ \\
\hline & & $\begin{array}{l}\text { External } \\
\text { rupture }\end{array}$ & $\begin{array}{l}\text { Fitting failure, } \\
\text { sensing line break }\end{array}$ & $\begin{array}{l}\text { High QA on parts, } \\
\text { installation. } \\
\text { Periodic inspection }\end{array}$ & $\begin{array}{l}\text { PS-1 is failed, system is } \\
\text { leaking gas to port cell. } \\
\text { ITER outage until repaired. }\end{array}$ & $\begin{array}{l}\text { Isolate gas from the } \\
\text { break. Repair sensor as } \\
\text { soon as possible. }\end{array}$ & $\begin{array}{l}\text { Assume 1-m sensing line. } \\
\text { Replace sensor, return system to } \\
\text { service, assume } S=2\end{array}$ & $\begin{array}{l}3.3 \mathrm{E}-09 / \mathrm{h} \\
3000 \mathrm{~h} / \mathrm{y} \\
\mathrm{O}=1\end{array}$ & $\begin{array}{l}\text { Blanchard } \\
1998, \text { no k } \\
\text { factor }\end{array}$ & $2 \times 1=2$ & \\
\hline \multirow[t]{5}{*}{$\begin{array}{l}\text { Gas valve near PS-1, } \\
\text { Valve-2 } \\
\text { (assume motor } \\
\text { operated valve) }\end{array}$} & $\begin{array}{l}\text { Normally } \\
\text { closed }\end{array}$ & $\begin{array}{l}\text { Spurious } \\
\text { operation }\end{array}$ & $\begin{array}{l}\text { Command fault, } \\
\text { human error, } \\
\text { electronic noise }\end{array}$ & $\begin{array}{l}\text { Periodic testing, } \\
\text { software QA }\end{array}$ & $\begin{array}{l}\text { Valve opens, unisolates PS-1 } \\
\text { sensor. Leaves sensor } \\
\text { exposed to pressure pulse of } \\
\text { DM valve operation. }\end{array}$ & $\begin{array}{l}\text { Can operate system with } \\
\text { this failure. Repair valve } \\
\text { to regain system } \\
\text { integrity. }\end{array}$ & Hale 2001, MTTR $=8$ h, so $S=2$ & $\begin{array}{l}6.18 \mathrm{E}-07 \mathrm{~h} \\
3000 \mathrm{~h} / \mathrm{y} \\
\mathrm{O}=2\end{array}$ & $\begin{array}{l}\text { Blanchard } \\
1998, \\
\text { Table 2-4 k } \\
\text { factor of } \\
2.06\end{array}$ & $2 \times 2=4$ & $\begin{array}{l}\text { DM valve operation could damage } \\
\text { PS-1 by pressure pulsations from } \\
\text { the closure volume. }\end{array}$ \\
\hline & & Plugging & $\begin{array}{l}\text { Moisture in system } \\
\text { may create rust } \\
\text { that fouls valve, } \\
\text { foreign material in } \\
\text { system such as } \\
\text { hydrocarbons gum } \\
\text { up valve disk and } \\
\text { seat }\end{array}$ & $\begin{array}{l}\text { Regular sampling } \\
\text { of gas in system for } \\
\text { impurities and } \\
\text { foreign materials, } \\
\text { monitor moisture in } \\
\text { system }\end{array}$ & $\begin{array}{l}\text { Cannot charge the MGI DM } \\
\text { valve closure volume with } \\
\text { appropriate gas pressure, so } \\
\text { DM valve is not optimum } \\
\text { but can function. Longer } \\
\text { than } 3 \text { hours to restore DM } \\
\text { valve. }\end{array}$ & $\begin{array}{l}\text { Can operate system with } \\
\text { this failure. Repair valve } \\
\text { to regain system } \\
\text { integrity. }\end{array}$ & $\begin{array}{l}\text { Cleaning gas piping is a difficult } \\
\text { repair, assume } S=3\end{array}$ & $\begin{array}{l}5 \mathrm{E}-07 / \mathrm{h} \\
\text { and } \\
3000 \mathrm{~h} / \mathrm{y} \\
\mathrm{O}=2\end{array}$ & $\begin{array}{l}\text { Blanchard } \\
1998, \text { no k } \\
\text { factor } \\
\text { assigned }\end{array}$ & $3 \times 2=6$ & $\begin{array}{l}\text { The cleaning task would be to } \\
\text { flush piping with cleaning agent, } \\
\text { keeping moisture out of piping. }\end{array}$ \\
\hline & & $\begin{array}{l}\text { Internal leak } \\
\text { past seat }\end{array}$ & $\begin{array}{l}\text { Seat wear, not } \\
\text { fully seated by } \\
\text { valve operator }\end{array}$ & $\begin{array}{l}\text { Regular sampling } \\
\text { of gas in system for } \\
\text { foreign materials, } \\
\text { check motor current }\end{array}$ & $\begin{array}{l}\text { Minor degradation of } \\
\text { system. }\end{array}$ & $\begin{array}{l}\text { Repair valve next } \\
\text { outage. }\end{array}$ & Hale $2001, \mathrm{MTTR}=8 \mathrm{~h}$, so $\mathrm{S}=2$ & $\begin{array}{l}1 \mathrm{E}-05 / \mathrm{h} \\
3000 \mathrm{~h} / \mathrm{y} \\
\mathrm{O}=4\end{array}$ & $\begin{array}{l}\text { Blanchard } \\
1998, \text { no k } \\
\text { factor } \\
\text { assigned }\end{array}$ & $2 \times 4=8$ & $\begin{array}{l}\text { Leak past the seat is difficult to } \\
\text { detect. }\end{array}$ \\
\hline & & External leak & $\begin{array}{l}\text { Stem seal } \\
\text { degradation, valve } \\
\text { body crack }\end{array}$ & $\begin{array}{l}\text { High QA on valve, } \\
\text { periodic inspection } \\
\text { of stem seal }\end{array}$ & $\begin{array}{l}\text { Wasting gas from the ITER } \\
\text { gas supply. System can } \\
\text { operate with a small leak. }\end{array}$ & $\begin{array}{l}\text { Repair valve next } \\
\text { outage. }\end{array}$ & $\begin{array}{l}\text { Replacing a valve and returning } \\
\text { the system to service, judgment } \\
\text { is } S=3\end{array}$ & $\begin{array}{l}1 \mathrm{E}-07 / \mathrm{h} \\
3000 \mathrm{~h} / \mathrm{y} \\
\mathrm{O}=2\end{array}$ & $\begin{array}{l}\text { Blanchard } \\
1998, \text { no k } \\
\text { factor } \\
\text { assigned }\end{array}$ & $3 \times 2=6$ & $\begin{array}{l}\text { Gas leak into port cell may not be } \\
\text { easy to detect. }\end{array}$ \\
\hline & & $\begin{array}{l}\text { External } \\
\text { rupture }\end{array}$ & $\begin{array}{l}\text { Stem seal failure, } \\
\text { valve body failure }\end{array}$ & $\begin{array}{l}\text { High QA on valve, } \\
\text { periodic inspection } \\
\text { of stem seal }\end{array}$ & $\begin{array}{l}\text { Cannot charge DM valve } \\
\text { closure volume, ITER } \\
\text { outage until repaired. }\end{array}$ & $\begin{array}{l}\text { Repair valve to regain } \\
\text { system operability. }\end{array}$ & $\begin{array}{l}\text { Replacing a valve and returning } \\
\text { the system to service, judgment } \\
\text { is } S=3\end{array}$ & $\begin{array}{l}5 \mathrm{E}-09 / \mathrm{h} \\
3000 \mathrm{~h} / \mathrm{y} \\
\mathrm{O}=1\end{array}$ & $\begin{array}{l}\text { Blanchard } \\
1998, \text { no k } \\
\text { factor } \\
\text { assigned }\end{array}$ & $3 \times 1=3$ & \\
\hline \multirow[t]{2}{*}{$\begin{array}{l}\text { Deuterium } \\
\text { compressor, Comp-2 }\end{array}$} & $\begin{array}{l}\text { Shutdown } \\
\text { during } \\
\text { system } \\
\text { operation }\end{array}$ & Fails to start & $\begin{array}{l}\text { Electronics fault in } \\
\text { control circuitry, } \\
\text { software error, loss } \\
\text { of power, human } \\
\text { error, mechanical } \\
\text { fault }\end{array}$ & $\begin{array}{l}\text { Regular test, } \\
\text { regular inspection, } \\
\text { software QA, } \\
\text { diverse power } \\
\text { supplies, detailed } \\
\text { operating } \\
\text { procedures }\end{array}$ & $\begin{array}{l}\text { Cannot charge the MGI DM } \\
\text { valves with deuterium, but } \\
\text { can run DM valves with Ar- } \\
\text { Ne mix so DM system can } \\
\text { still protect vacuum vessel. }\end{array}$ & $\begin{array}{l}\text { Repair compressor to } \\
\text { regain system } \\
\text { operability }\end{array}$ & $\begin{array}{l}\text { Hale (2001) gives some repair } \\
\text { times. Compressors }<10 \mathrm{~h} \text { for } \\
\text { MTTR. Thus, } \mathrm{S}=2\end{array}$ & $\begin{array}{l}6.25 \mathrm{E}-03 / \mathrm{d} \\
\text { and } \\
200 \mathrm{~d} / \mathrm{y} \\
\mathrm{O}=5\end{array}$ & $\begin{array}{l}\text { Blanchard } \\
1998, \\
\text { Table 2-4 } \mathrm{k} \\
\text { factor of } \\
1.25 .\end{array}$ & $2 \times 5=10$ & \\
\hline & & Fails to run & $\begin{array}{l}\text { Electronics fault in } \\
\text { control circuitry, } \\
\text { software error, loss } \\
\text { of power, human } \\
\text { error, mechanical } \\
\text { fault }\end{array}$ & $\begin{array}{l}\text { Regular test, } \\
\text { regular inspection, } \\
\text { software QA, } \\
\text { diverse power } \\
\text { supplies, detailed } \\
\text { operating } \\
\text { procedures }\end{array}$ & $\begin{array}{l}\text { Cannot charge the MGI DM } \\
\text { valves with deuterium, but } \\
\text { can run DM valves with Ar- } \\
\text { Ne mix so can protect } \\
\text { vacuum vessel. }\end{array}$ & $\begin{array}{l}\text { Repair compressor to } \\
\text { regain system } \\
\text { operability }\end{array}$ & $\begin{array}{l}\text { Hale (2001) gives some repair } \\
\text { times. Compressors }<10 \mathrm{~h} \text { for } \\
\text { MTTR. Thus, } S=2\end{array}$ & $\begin{array}{l}6.25 \mathrm{E}-05 / \mathrm{h} \\
\text { and } \\
200 \mathrm{~d} / \mathrm{y} \\
\text { and } 3 \mathrm{~h} / \mathrm{d} \\
\mathrm{O}=3\end{array}$ & $\begin{array}{l}\text { Blanchard } \\
1998, \\
\text { Table 2-4 } \mathrm{k} \\
\text { factor of } \\
1.25 .\end{array}$ & $2 \times 3=6$ & \\
\hline
\end{tabular}




\begin{tabular}{|c|c|c|c|c|c|c|c|c|c|c|c|}
\hline Component & $\begin{array}{l}\text { Operational } \\
\text { State }\end{array}$ & Failure Mode & Possible Causes & $\begin{array}{l}\text { Preventive Action } \\
\text { on Possible Causes }\end{array}$ & Consequences & $\begin{array}{c}\text { Corrective or } \\
\text { Preventive Actions on } \\
\text { Consequences } \\
\end{array}$ & Comments & $\begin{array}{l}\text { Failure } \\
\text { rate }\end{array}$ & \begin{tabular}{|c|}
$\begin{array}{c}\text { Comment } \\
\text { on failure } \\
\text { rate }\end{array}$ \\
\end{tabular} & $\begin{array}{c}\text { Criticality } \\
\text { Number } \\
\mathrm{S} \cdot \mathrm{O}=\mathrm{C}\end{array}$ & Design comments \\
\hline \multirow[t]{7}{*}{ Comp-2, continued } & $\begin{array}{l}\text { Shutdown } \\
\text { during } \\
\text { system } \\
\text { operation }\end{array}$ & Overspeed & $\begin{array}{l}\text { Electronics fault in } \\
\text { control circuitry, } \\
\text { software error }\end{array}$ & $\begin{array}{l}\text { Regular test, and } \\
\text { software QA }\end{array}$ & $\begin{array}{l}\text { Overpressurize the gases, the } \\
\text { system should compensate } \\
\text { back to correct pressure }\end{array}$ & $\begin{array}{l}\text { No immediate repair } \\
\text { needed, but should } \\
\text { investigate at first } \\
\text { opportunity }\end{array}$ & $\begin{array}{l}\text { Hale (2001) gives some repair } \\
\text { times. Compressors }<10 \mathrm{~h} \text { for } \\
\text { MTTR. Thus, } \mathrm{S}=2\end{array}$ & $\begin{array}{l}1.25 \mathrm{E}-05 / \mathrm{h} \\
\text { and } \\
200 \mathrm{~d} / \mathrm{y} \\
\text { and } 3 \mathrm{~h} / \mathrm{d} \\
\mathrm{O}=3\end{array}$ & \begin{tabular}{|l|} 
Blanchard \\
1998, \\
Table 2-4 $\mathrm{k}$ \\
factor of \\
1.25 \\
\end{tabular} & $2 \times 3=6$ & \\
\hline & & Underspeed & $\begin{array}{l}\text { Electronics fault in } \\
\text { control circuitry, } \\
\text { software error }\end{array}$ & $\begin{array}{l}\text { Regular test, and } \\
\text { software QA }\end{array}$ & $\begin{array}{l}\text { Underpressurizes the gases, } \\
\text { DM valves will not protect } \\
\text { vessel. Repair to restore } \\
\text { system operability. }\end{array}$ & $\begin{array}{l}\text { Repair compressor to } \\
\text { regain system } \\
\text { operability and ITER } \\
\text { operability }\end{array}$ & $\begin{array}{l}\text { Hale (2001) gives compressors < } \\
10 \mathrm{~h} \text { for MTTR. Thus, } \mathrm{S}=2\end{array}$ & $\begin{array}{l}1.25 \mathrm{E}-05 / \mathrm{h} \\
\text { and } \\
200 \mathrm{~d} / \mathrm{y} \\
\text { and } 3 \mathrm{~h} / \mathrm{d} \\
\mathrm{O}=3\end{array}$ & $\begin{array}{l}\text { Assumed from } \\
\text { Blanchard } \\
1998 \text {, Table 2- } \\
4 \mathrm{k} \text { factor of } \\
1.25 .\end{array}$ & $2 \times 3=6$ & \\
\hline & & Fails to stop & $\begin{array}{l}\text { Electronics fault in } \\
\text { control circuitry, } \\
\text { software error }\end{array}$ & $\begin{array}{l}\text { Regular test, and } \\
\text { software QA }\end{array}$ & $\begin{array}{l}\text { Overpressurize the gases, the } \\
\text { system should compensate } \\
\text { back to correct pressure. }\end{array}$ & $\begin{array}{l}\text { Operator can depower } \\
\text { compressor from a } \\
\text { motor control center or } \\
\text { panel. Should repair. }\end{array}$ & $\begin{array}{l}\text { Compressors }<10 \mathrm{~h} \text { for MTTR. } \\
\text { Thus, } \mathrm{S}=2\end{array}$ & $\begin{array}{l}5 \mathrm{E}-03 / \mathrm{d} \\
\text { and } \\
200 \mathrm{~d} / \mathrm{y} \\
\mathrm{O}=5\end{array}$ & $\begin{array}{l}\text { Blanchard } \\
1998, \\
\text { Table 2-4 } \mathrm{k} \\
\text { factor of } \\
1.25 . \\
\end{array}$ & $2 \times 5=10$ & \\
\hline & & $\begin{array}{l}\text { Leakage at } \\
\text { outlet side }\end{array}$ & $\begin{array}{l}\text { Shaft seal fault, } \\
\text { small crack }\end{array}$ & $\begin{array}{l}\text { Regular test and } \\
\text { inspection }\end{array}$ & $\begin{array}{l}\text { Lose system pressure. Leak } \\
\text { deuterium into port cell. }\end{array}$ & $\begin{array}{l}\text { Cannot reach specified } \\
\text { gas pressure for DM } \\
\text { valve }\end{array}$ & $\begin{array}{l}\text { Deuterium LFL in air is } 4.9 \% \\
\text { (ANSI, 2010). Hale }(2001) \\
\text { Compressors }<10 \mathrm{~h} \text { for MTTR. } \\
\text { Thus, } \mathrm{S}=2\end{array}$ & $\begin{array}{l}3 \mathrm{E}-07 / \mathrm{h} \\
200 \mathrm{~d} / \mathrm{y} \\
\text { and } 3 \mathrm{~h} / \mathrm{d} \\
\mathrm{O}=1\end{array}$ & $\begin{array}{l}\text { Blanchard } \\
1998, \text { no k } \\
\text { factor } \\
\text { needed }\end{array}$ & $2 \times 1=2$ & $\begin{array}{l}\text { Deuterium leak into port cell } \\
\text { could present a gas deflagration } \\
\text { concern. Perhaps port cell has } \\
\text { hydrogen specie monitor? }\end{array}$ \\
\hline & & $\begin{array}{l}\text { Leakage at } \\
\text { inlet side }\end{array}$ & $\begin{array}{l}\text { Shaft seal fault, } \\
\text { small crack }\end{array}$ & $\begin{array}{l}\text { Regular test and } \\
\text { inspection }\end{array}$ & $\begin{array}{l}\text { Compressor could draw } \\
\text { room air into gas stream, or } \\
\text { leak gas, depending on inlet } \\
\text { gas pressure. }\end{array}$ & $\begin{array}{l}\text { Possible explosive gas } \\
\text { mixture }\end{array}$ & $\begin{array}{l}\text { Deuterium UFL in air is } 75 \% \\
\text { (ANS } 2010) \text {. Hale }(2000) \text { gives } \\
\text { compressors }<10 \text { h for MTTR. } \\
\text { Thus, } \mathrm{S}=2\end{array}$ & $\begin{array}{l}3 \mathrm{E}-07 / \mathrm{h} \\
200 \mathrm{~d} / \mathrm{y} \\
\text { and } 3 \mathrm{~h} / \mathrm{d} \\
\mathrm{O}=1\end{array}$ & $\begin{array}{l}\text { Blanchard } \\
1998, \text { no k } \\
\text { factor } \\
\text { needed }\end{array}$ & $2 \times 1=3$ & $\begin{array}{l}\text { A leak of air into compression } \\
\text { heated } \mathrm{D}_{2} \text { could easily deflagrate. } \\
\text { Perhaps port cell has hydrogen } \\
\text { specie monitor? }\end{array}$ \\
\hline & & Rupture & $\begin{array}{l}\text { Shaft seal failure, } \\
\text { catastrophic crack }\end{array}$ & $\begin{array}{l}\text { Regular test and } \\
\text { inspection }\end{array}$ & Lose outlet gas pressure. & $\begin{array}{l}\text { Repair or replace } \\
\text { compressor to regain } \\
\text { system operability and } \\
\text { ITER operability }\end{array}$ & $\begin{array}{l}\text { Rupture assumed to require } \\
\text { replacement. Assume }<1 \text { week. } \\
\text { Thus } S=3\end{array}$ & $\begin{array}{l}1 \mathrm{E}-08 / \mathrm{h} \\
200 \mathrm{~d} / \mathrm{y} \\
\text { and } 3 \mathrm{~h} / \mathrm{d} \\
\mathrm{O}=1\end{array}$ & $\begin{array}{l}\text { Blanchard } \\
1998, \text { no } \mathrm{k} \\
\text { factor } \\
\text { needed }\end{array}$ & $3 \times 1=3$ & $\begin{array}{l}\text { Large deuterium leak in port cell. } \\
\text { Perhaps port cell has hydrogen } \\
\text { specie monitor? }\end{array}$ \\
\hline & & $\begin{array}{l}\text { Contam- } \\
\text { ination }\end{array}$ & $\begin{array}{l}\text { Lube oil leaks by } \\
\text { seals into gas }\end{array}$ & $\begin{array}{l}\text { Compressor } \\
\text { selection to } \\
\text { preclude lube oil } \\
\text { intrusion issue }\end{array}$ & $\begin{array}{l}\text { Gas is contaminated with oil, } \\
\text { oil enters vacuum vessel, } \\
\text { degrades vacuum. }\end{array}$ & $\begin{array}{l}\text { Select oil-less } \\
\text { compressor, or use } \\
\text { filters on compressor } \\
\text { outlet }\end{array}$ & $\begin{array}{l}\text { Oil often contaminates the gas in } \\
\text { the compressor. Oil molecules } \\
\text { become irradiated close to the } \\
\text { tokamak, oil plugs filters, fouls } \\
\text { values. Difficult repair, assume } \\
\mathrm{S}=4\end{array}$ & $\begin{array}{l}1 / \mathrm{h} \\
\mathrm{O}=6\end{array}$ & $\begin{array}{l}\text { Analyst } \\
\text { judgment, } \\
\text { no k factor } \\
\text { needed }\end{array}$ & $4 \times 6=24$ & $\begin{array}{l}\text { Assume a low oil or oil-less type } \\
\text { of compressor is selected, perhaps } \\
\text { a diaphragm compressor. Filters } \\
\text { were not specified on the } \\
\text { compressor outlet. Filters are } \\
\text { recommended (Walker, 2011, p. } \\
\text { 96-97), but filters can become } \\
\text { plugged up. }\end{array}$ \\
\hline \multirow[t]{2}{*}{$\begin{array}{l}\text { Gas metering device, } \\
\text { Meter-1 }\end{array}$} & $\begin{array}{l}\text { Measures gas } \\
\text { amount, } \\
\text { controls gas } \\
\text { flow to DM } \\
\text { valve }\end{array}$ & $\begin{array}{l}\text { Fails to } \\
\text { operate }\end{array}$ & $\begin{array}{l}\text { Valve sticks shut, } \\
\text { controller failure, } \\
\text { thermal tube } \\
\text { blocked or coated } \\
\text { with foreign } \\
\text { material }\end{array}$ & $\begin{array}{l}\text { Maintain gas } \\
\text { cleanliness, regular } \\
\text { test and inspection }\end{array}$ & $\begin{array}{l}\text { Gas mixture is not supplied } \\
\text { to DM valve. DM valve } 1- \\
\text { liter chamber is not charged. } \\
\text { System is not operable. }\end{array}$ & $\begin{array}{l}\text { Repair mass flow } \\
\text { controller to regain } \\
\text { system operation and } \\
\text { ITER operation. }\end{array}$ & $\begin{array}{l}\text { It may be easiest to replace the } \\
\text { unit with a spare. Assume } S=1\end{array}$ & $\begin{array}{l}1.375 \mathrm{E}-06 / \mathrm{h} \\
200 \mathrm{~d} / \mathrm{y} \\
3 \mathrm{~h} / \mathrm{d} \\
\mathrm{O}=2\end{array}$ & $\begin{array}{l}\text { Drexel, } \\
1996, \\
\text { Table 2-4 } \mathrm{k} \\
\text { factor of } \\
1.25 .\end{array}$ & $1 \times 2=2$ & $\begin{array}{l}\text { Assume MFC is adequately } \\
\text { shielded from magnetic fields, } \\
\text { otherwise, no } \mathrm{k} \text { factors are needed } \\
\text { for } \mathrm{T}, \mathrm{P} \text {, humidity. }\end{array}$ \\
\hline & & Plugging & $\begin{array}{l}\text { Foreign material } \\
\text { intrusion }\end{array}$ & $\begin{array}{l}\text { Maintain gas } \\
\text { cleanliness }\end{array}$ & $\begin{array}{l}\text { Gas mixture is not supplied } \\
\text { to DM valve. DM valve 1- } \\
\text { liter chamber is not charged. } \\
\text { System is not operable. }\end{array}$ & $\begin{array}{l}\text { Repair mass flow } \\
\text { controller to regain } \\
\text { system operation and } \\
\text { ITER operation. }\end{array}$ & $\begin{array}{l}\text { It may be easiest to replace the } \\
\text { unit with a spare. Assume } S=1\end{array}$ & $\begin{array}{l}5 \mathrm{E}-07 / \mathrm{h} \\
200 \mathrm{~d} / \mathrm{y} \\
3 \mathrm{~h} / \mathrm{d} \\
\mathrm{O}=1\end{array}$ & $\begin{array}{l}\text { Analyst } \\
\text { judgment, } \\
\text { no k factor }\end{array}$ & $1 \times 1=1$ & \\
\hline
\end{tabular}




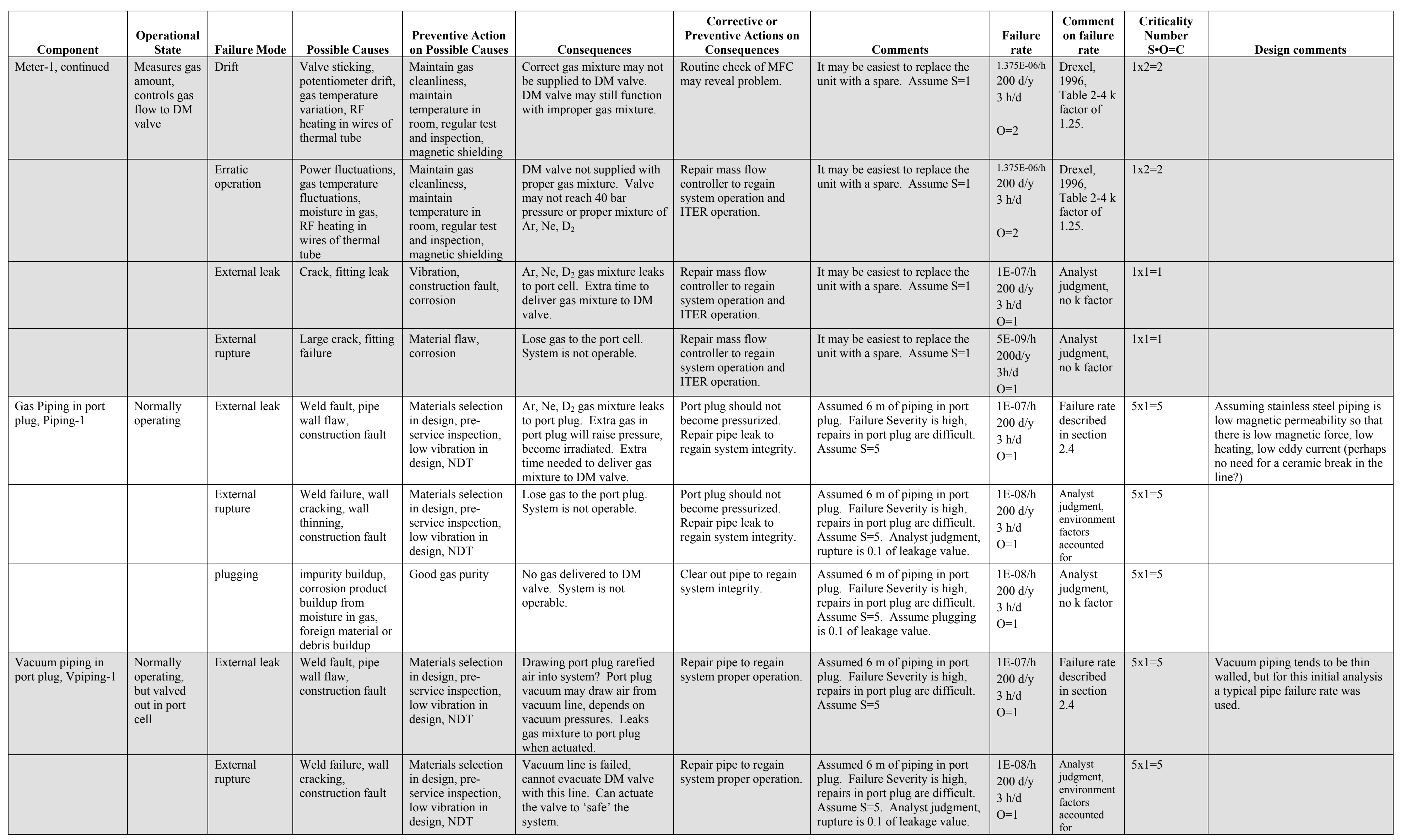




\begin{tabular}{|c|c|c|c|c|c|c|c|c|c|c|c|}
\hline Component & $\begin{array}{c}\text { Operational } \\
\text { State }\end{array}$ & Failure Mode & Possible Causes & $\begin{array}{l}\text { Preventive Action } \\
\text { on Possible Causes }\end{array}$ & Consequences & $\begin{array}{c}\text { Corrective or } \\
\text { Preventive Actions on } \\
\text { Consequences }\end{array}$ & Comments & $\begin{array}{l}\text { Failure } \\
\text { rate }\end{array}$ & $\begin{array}{l}\text { Comment } \\
\text { on failure } \\
\text { rate }\end{array}$ & $\begin{array}{c}\text { Criticality } \\
\text { Number } \\
\mathrm{S} \cdot \mathrm{O}=\mathrm{C}\end{array}$ & Design comments \\
\hline Vpiping-1, continued & $\begin{array}{l}\text { Normally } \\
\text { operating, } \\
\text { but valved } \\
\text { out in port } \\
\text { cell }\end{array}$ & plugging & $\begin{array}{l}\text { Foreign material or } \\
\text { debris buildup } \\
\text { creates poor } \\
\text { conductance }\end{array}$ & $\begin{array}{l}\text { Good gas purity, } \\
\text { vespel seal integrity }\end{array}$ & $\begin{array}{l}\text { Vacuum line is failed, } \\
\text { cannot evacuate DM valve } \\
\text { with this line. Can actuate } \\
\text { the valve to 'safe' the } \\
\text { system. }\end{array}$ & $\begin{array}{l}\text { Clear out pipe to regain } \\
\text { system proper operation. }\end{array}$ & $\begin{array}{l}\text { Assumed } 6 \mathrm{~m} \text { of piping in port } \\
\text { plug. Failure Severity is high, } \\
\text { repairs in port plug are difficult. } \\
\text { Assume } S=5 \text {. Assume plugging } \\
\text { is } 0.1 \text { of leakage value. }\end{array}$ & $\begin{array}{l}1 \mathrm{E}-08 / \mathrm{h} \\
200 \mathrm{~d} / \mathrm{y} \\
3 \mathrm{~h} / \mathrm{d} \\
\mathrm{O}=1\end{array}$ & \begin{tabular}{l|} 
Analyst \\
judgment
\end{tabular} & $5 \times 1=5$ & \\
\hline \multirow[t]{3}{*}{$\begin{array}{l}\text { Gas Piping in port } \\
\text { cell, Piping-2 }\end{array}$} & $\begin{array}{l}\text { Normally } \\
\text { operating }\end{array}$ & External leak & $\begin{array}{l}\text { Weld fault, pipe } \\
\text { wall flaw, } \\
\text { construction fault }\end{array}$ & $\begin{array}{l}\text { Materials selection } \\
\text { in design, pre- } \\
\text { service inspection, } \\
\text { low vibration in } \\
\text { design, NDT }\end{array}$ & $\begin{array}{l}\mathrm{Ar}, \mathrm{Ne}, \mathrm{D}_{2} \text { gas mixture leaks } \\
\text { to port cell. Explosion } \\
\text { concern? } \mathrm{D}_{2} \mathrm{LFL} \text { is } 4.9 \% \text { in } \\
\text { air. Extra time needed to } \\
\text { deliver gas mixture to DM } \\
\text { valve. }\end{array}$ & $\begin{array}{l}\text { Repair pipe leak to } \\
\text { regain system integrity. }\end{array}$ & $\begin{array}{l}\text { Assumed } 30 \mathrm{~m} \text { of piping in port } \\
\text { cell. Failure Severity is } \\
\text { moderate, pipe repairs should be } \\
\text { less than a week. Assume } \mathrm{S}=3 \text {. }\end{array}$ & $\begin{array}{l}5.1 \mathrm{E}-07 / \mathrm{h} \\
200 \mathrm{~d} / \mathrm{y} \\
3 \mathrm{~h} / \mathrm{d} \\
\mathrm{O}=1\end{array}$ & $\begin{array}{l}\text { Failure rate } \\
\text { described } \\
\text { in section } \\
2.4\end{array}$ & $3 \times 1=3$ & $\begin{array}{l}\text { Assuming stainless steel piping is } \\
\text { low magnetic permeability so that } \\
\text { there is low magnetic force, low } \\
\text { heating, low eddy current (maybe } \\
\text { no need for ceramic break in line) }\end{array}$ \\
\hline & & $\begin{array}{l}\text { External } \\
\text { rupture }\end{array}$ & $\begin{array}{l}\text { Weld failure, wall } \\
\text { cracking, wall } \\
\text { thinning, } \\
\text { construction fault }\end{array}$ & $\begin{array}{l}\text { Materials selection } \\
\text { in design, pre- } \\
\text { service inspection, } \\
\text { low vibration in } \\
\text { design, NDT }\end{array}$ & $\begin{array}{l}\text { Lose gas to the port plug. } \\
\text { System is not operable. } \\
\text { Explosion concern? } \mathrm{D}_{2} \mathrm{LFL} \\
\text { is } 4.9 \% \text { in air. }\end{array}$ & $\begin{array}{l}\text { Repair pipe leak to } \\
\text { regain system integrity. }\end{array}$ & $\begin{array}{l}\text { Assumed } 30 \mathrm{~m} \text { of piping in port } \\
\text { cell. Failure Severity is } \\
\text { moderate, pipe repairs should be } \\
\text { less than a week. Assume } S=3 \text {. } \\
\text { Analyst judgment, rupture is } 0.1 \\
\text { of leakage value. }\end{array}$ & $\begin{array}{l}5.1 \mathrm{E}-08 / \mathrm{h} \\
200 \mathrm{~d} / \mathrm{y} \\
3 \mathrm{~h} / \mathrm{d} \\
\mathrm{O}=1\end{array}$ & $\begin{array}{l}\text { Analyst } \\
\text { judgment, } \\
\text { environment } \\
\text { factors } \\
\text { accounted } \\
\text { for }\end{array}$ & $3 \times 1=3$ & \\
\hline & & plugging & \begin{tabular}{|l|} 
impurity buildup, \\
corrosion product \\
buildup from \\
moisture in gas, \\
foreign material or \\
debris buildup \\
\end{tabular} & Good gas purity & $\begin{array}{l}\text { No gas delivered to DM } \\
\text { valve. System is not } \\
\text { operable. }\end{array}$ & $\begin{array}{l}\text { Clear out pipe to regain } \\
\text { system integrity. }\end{array}$ & $\begin{array}{l}\text { Assumed } 30 \mathrm{~m} \text { of piping in port } \\
\text { cell. Failure Severity is } \\
\text { moderate, pipe repairs should be } \\
\text { less than a week. Assume } \mathrm{S}=3 \text {. } \\
\text { Analyst judgment, plugging is } \\
0.1 \text { of leakage value. }\end{array}$ & $\begin{array}{l}5.1 \mathrm{E}-08 / \mathrm{h} \\
200 \mathrm{~d} / \mathrm{y} \\
3 \mathrm{~h} / \mathrm{d} \\
\mathrm{O}=1\end{array}$ & $\begin{array}{l}\text { Analyst } \\
\text { judgment, } \\
\text { no k factor }\end{array}$ & $3 \times 1=3$ & \\
\hline \multirow{2}{*}{$\begin{array}{l}\text { Vacuum piping in } \\
\text { port cell, Vpiping-2 }\end{array}$} & & $\begin{array}{l}\text { External } \\
\text { rupture }\end{array}$ & $\begin{array}{l}\text { Weld failure, wall } \\
\text { cracking, } \\
\text { construction fault }\end{array}$ & $\begin{array}{l}\text { Materials selection } \\
\text { in design, pre- } \\
\text { service inspection, } \\
\text { low vibration in } \\
\text { design, NDT }\end{array}$ & $\begin{array}{l}\text { Vacuum line is failed, } \\
\text { cannot evacuate DM valve } \\
\text { with this line. Can actuate } \\
\text { the valve to 'safe' the } \\
\text { system. }\end{array}$ & $\begin{array}{l}\text { Repair pipe to regain } \\
\text { system proper operation. }\end{array}$ & $\begin{array}{l}\text { Assumed } 6 \mathrm{~m} \text { of piping in port } \\
\text { plug. Failure Severity is } \\
\text { moderate, pipe repair should be } \\
\text { less than a week. Assume } \mathrm{S}=3 \text {. } \\
\text { Analyst judgment, rupture is } 0.1 \\
\text { of leakage value. }\end{array}$ & $\begin{array}{l}1 \mathrm{E}-08 / \mathrm{h} \\
200 \mathrm{~d} / \mathrm{y} \\
3 \mathrm{~h} / \mathrm{d} \\
\mathrm{O}=1\end{array}$ & $\begin{array}{l}\text { Analyst } \\
\text { judgment, } \\
\text { environment } \\
\text { factors } \\
\text { accounted } \\
\text { for }\end{array}$ & $5 \times 1=5$ & \\
\hline & & Plugging & $\begin{array}{l}\text { Foreign material or } \\
\text { debris buildup } \\
\text { creates poor } \\
\text { conductance }\end{array}$ & $\begin{array}{l}\text { Good gas purity, } \\
\text { vespel seal integrity }\end{array}$ & $\begin{array}{l}\text { Vacuum line is failed, } \\
\text { cannot evacuate DM valve } \\
\text { with this line. Can actuate } \\
\text { the valve to 'safe' the } \\
\text { system. }\end{array}$ & $\begin{array}{l}\text { Clear out pipe to regain } \\
\text { system proper operation. }\end{array}$ & $\begin{array}{l}\text { Assumed } 6 \mathrm{~m} \text { of piping in port } \\
\text { plug. Failure Severity is } \\
\text { moderate, pipe repair should be } \\
\text { less than a week. Assume } \mathrm{S}=3 \text {. } \\
\text { Assume plugging is } 0.1 \text { of } \\
\text { leakage value. }\end{array}$ & $\begin{array}{l}1 \mathrm{E}-08 / \mathrm{h} \\
200 \mathrm{~d} / \mathrm{y} \\
3 \mathrm{~h} / \mathrm{d} \\
\mathrm{O}=1\end{array}$ & $\begin{array}{l}\text { Analyst } \\
\text { judgment, } \\
\text { no k factor }\end{array}$ & $5 \times 1=5$ & \\
\hline \multirow[t]{2}{*}{$\begin{array}{l}\text { Meter outlet valve, } \\
\text { Valve-3 } \\
\text { (isolates Meter-1 } \\
\text { when using vacuum } \\
\text { line) }\end{array}$} & $\begin{array}{l}\text { Normally } \\
\text { closed }\end{array}$ & $\begin{array}{l}\text { Spurious } \\
\text { operation }\end{array}$ & $\begin{array}{l}\text { Command fault, } \\
\text { human error, } \\
\text { electronic noise }\end{array}$ & $\begin{array}{l}\text { Periodic testing, } \\
\text { software QA, noise } \\
\text { shielding }\end{array}$ & $\begin{array}{l}\text { Valve opens, unisolates } \\
\text { Meter-1. }\end{array}$ & $\begin{array}{l}\text { Can operate system with } \\
\text { this failure. Repair valve } \\
\text { to regain system } \\
\text { integrity. }\end{array}$ & Hale 2001, MTTR $=8$ h, so $S=2$ & $\begin{array}{l}6.18 \mathrm{E}-07 / \mathrm{h} \\
3000 \mathrm{~h} / \mathrm{y} \\
\mathrm{O}=2\end{array}$ & $\begin{array}{l}\text { Blanchard } \\
1998, \\
\text { Table 2-4 k } \\
\text { factor of } \\
2.06\end{array}$ & $2 \times 2=4$ & \\
\hline & & Plugging & $\begin{array}{l}\text { Moisture in system } \\
\text { may create rust } \\
\text { that fouls valve, } \\
\text { foreign material in } \\
\text { system such as } \\
\text { hydrocarbons gum } \\
\text { up valve disk and } \\
\text { seat }\end{array}$ & $\begin{array}{l}\text { Regular sampling } \\
\text { of gas in system for } \\
\text { impurities and } \\
\text { foreign materials, } \\
\text { monitor moisture in } \\
\text { system }\end{array}$ & $\begin{array}{l}\text { Cannot charge the MGI DM } \\
\text { valve closure volume with } \\
\text { appropriate gas pressure, so } \\
\text { DM valve is not optimum } \\
\text { but can function. Longer } \\
\text { than } 3 \text { hours to restore DM } \\
\text { valve. }\end{array}$ & $\begin{array}{l}\text { Can operate system with } \\
\text { this failure. Repair valve } \\
\text { to regain system } \\
\text { integrity. }\end{array}$ & $\begin{array}{l}\text { Cleaning gas piping is a difficult } \\
\text { repair, assume } \mathrm{S}=3\end{array}$ & $\begin{array}{l}5 \mathrm{E}-07 / \mathrm{h} \\
\text { and } \\
3000 \mathrm{~h} / \mathrm{y} \\
\mathrm{O}=2\end{array}$ & $\begin{array}{l}\text { Blanchard } \\
\text { 1998, no k } \\
\text { factor } \\
\text { assigned }\end{array}$ & $3 \times 2=6$ & $\begin{array}{l}\text { The cleaning task would be to } \\
\text { flush piping with cleaning agent, } \\
\text { keeping moisture out of piping. }\end{array}$ \\
\hline
\end{tabular}




\begin{tabular}{|c|c|c|c|c|c|c|c|c|c|c|c|}
\hline Component & $\begin{array}{c}\text { Operational } \\
\text { State }\end{array}$ & Failure Mode & Possible Causes & $\begin{array}{l}\text { Preventive Action } \\
\text { on Possible Causes }\end{array}$ & Consequences & $\begin{array}{c}\text { Corrective or } \\
\text { Preventive Actions on } \\
\text { Consequences }\end{array}$ & Comments & $\begin{array}{l}\text { Failure } \\
\text { rate }\end{array}$ & $\begin{array}{l}\text { Comment } \\
\text { on failure } \\
\text { rate }\end{array}$ & $\begin{array}{c}\text { Criticality } \\
\text { Number } \\
S \cdot O=C\end{array}$ & Design comments \\
\hline \multirow[t]{4}{*}{ Valve-3, continued } & $\begin{array}{l}\text { Normally } \\
\text { closed }\end{array}$ & $\begin{array}{l}\text { Internal leak } \\
\text { past seat }\end{array}$ & $\begin{array}{l}\text { Seat wear, not } \\
\text { fully seated by } \\
\text { valve operator }\end{array}$ & $\begin{array}{l}\text { Regular sampling } \\
\text { of gas in system for } \\
\text { foreign materials, } \\
\text { check motor current }\end{array}$ & $\begin{array}{l}\text { Minor degradation of } \\
\text { system. }\end{array}$ & $\begin{array}{l}\text { Repair valve next } \\
\text { outage. }\end{array}$ & Hale 2001, MTTR $=8$ h, so $S=2$ & $\begin{array}{l}1 \mathrm{E}-05 / \mathrm{h} \\
3000 \mathrm{~h} / \mathrm{y} \\
\mathrm{O}=4\end{array}$ & $\begin{array}{l}\text { Blanchard } \\
1998, \text { no k } \\
\text { factor } \\
\text { assigned } \\
\end{array}$ & $2 \times 4=8$ & $\begin{array}{l}\text { Leak past the seat is difficult to } \\
\text { detect. }\end{array}$ \\
\hline & & $\begin{array}{l}\text { Internal } \\
\text { rupture }\end{array}$ & $\begin{array}{l}\text { Valve disk failure, } \\
\text { seat mechanical } \\
\text { failure }\end{array}$ & High QA on valve & $\begin{array}{l}\text { Cannot isolate PS-1 from } \\
\text { pressure pulse of DM valve } \\
\text { operation, could fail sensor }\end{array}$ & $\begin{array}{l}\text { Repair valve to regain } \\
\text { system operability. }\end{array}$ & Analyst judgment is $\mathrm{S}=2$ & $\begin{array}{l}5 \mathrm{E}-07 / \mathrm{h} \\
3000 \mathrm{~h} / \mathrm{y} \\
\mathrm{O}=2\end{array}$ & $\begin{array}{l}\text { Blanchard } \\
1998, \text { no k } \\
\text { factor } \\
\text { assigned } \\
\end{array}$ & $2 \times 2=4$ & \\
\hline & & External leak & $\begin{array}{l}\text { Stem seal } \\
\text { degradation, valve } \\
\text { body crack }\end{array}$ & $\begin{array}{l}\text { High QA on valve, } \\
\text { periodic inspection } \\
\text { of stem seal }\end{array}$ & $\begin{array}{l}\text { Wasting gas from the ITER } \\
\text { gas supply. System can } \\
\text { operate with a small leak. }\end{array}$ & $\begin{array}{l}\text { Repair valve next } \\
\text { outage. }\end{array}$ & $\begin{array}{l}\text { Replacing a valve and returning } \\
\text { the system to service, judgment } \\
\text { is } S=3\end{array}$ & $\begin{array}{l}1 \mathrm{E}-07 / \mathrm{h} \\
3000 \mathrm{~h} / \mathrm{y} \\
\mathrm{O}=2\end{array}$ & $\begin{array}{l}\text { Blanchard } \\
1998, \text { no k } \\
\text { factor } \\
\text { assigned }\end{array}$ & $3 \times 2=6$ & $\begin{array}{l}\text { Gas leak into port cell may not be } \\
\text { easy to detect. }\end{array}$ \\
\hline & & $\begin{array}{l}\text { External } \\
\text { rupture }\end{array}$ & $\begin{array}{l}\text { Stem seal failure, } \\
\text { valve body failure }\end{array}$ & $\begin{array}{l}\text { High QA on valve, } \\
\text { periodic inspection } \\
\text { of stem seal }\end{array}$ & $\begin{array}{l}\text { Cannot charge DM valve 1- } \\
\text { liter volume, ITER outage } \\
\text { until repaired. }\end{array}$ & $\begin{array}{l}\text { Repair valve to regain } \\
\text { system operability. }\end{array}$ & $\begin{array}{l}\text { Replacing a valve and returning } \\
\text { the system to service, judgment } \\
\text { is } S=3\end{array}$ & $\begin{array}{l}5 \mathrm{E}-09 / \mathrm{h} \\
3000 \mathrm{~h} / \mathrm{y} \\
\mathrm{O}=1\end{array}$ & \begin{tabular}{|l|} 
Blanchard \\
1998, no k \\
factor \\
assigned
\end{tabular} & $3 \times 1=3$ & \\
\hline \multirow[t]{6}{*}{$\begin{array}{l}\text { Vacuum line } \\
\text { isolation valve, } \\
\text { Valve-4 }\end{array}$} & $\begin{array}{l}\text { Normally } \\
\text { closed }\end{array}$ & $\begin{array}{l}\text { Spurious } \\
\text { operation }\end{array}$ & $\begin{array}{l}\text { Command fault, } \\
\text { human error, } \\
\text { electronic noise }\end{array}$ & $\begin{array}{l}\text { Periodic testing, } \\
\text { software QA, noise } \\
\text { shielding }\end{array}$ & $\begin{array}{l}\text { Valve opens, draws down } \\
\text { gas between V-3 and V-5 } \\
\text { valves. }\end{array}$ & $\begin{array}{l}\text { Can operate system with } \\
\text { this failure. Repair valve } \\
\text { to regain full system } \\
\text { integrity. }\end{array}$ & Hale 2001, MTTR $=8$ h, so $S=2$ & $\begin{array}{l}6.18 \mathrm{E}-07 / \mathrm{h} \\
3000 \mathrm{~h} / \mathrm{y} \\
\mathrm{O}=2\end{array}$ & $\begin{array}{l}\text { Blanchard } \\
1998, \\
\text { Table 2-4 k } \\
\text { factor of } \\
2.06\end{array}$ & $2 \times 2=4$ & \\
\hline & & Plugging & $\begin{array}{l}\text { Moisture in system } \\
\text { may create rust } \\
\text { that fouls valve, } \\
\text { foreign material in } \\
\text { system such as } \\
\text { hydrocarbons gum } \\
\text { up valve disk and } \\
\text { seat }\end{array}$ & $\begin{array}{l}\text { Regular sampling } \\
\text { of gas in system for } \\
\text { impurities and } \\
\text { foreign materials, } \\
\text { monitor moisture in } \\
\text { system }\end{array}$ & $\begin{array}{l}\text { Cannot vacuum-purge gas } \\
\text { mixture from the MGI DM } \\
\text { valve volumes, can actuate } \\
\text { DM valve to 'safe' the valve. }\end{array}$ & $\begin{array}{l}\text { Can operate system with } \\
\text { this failure. Repair valve } \\
\text { to regain full system } \\
\text { integrity. }\end{array}$ & $\begin{array}{l}\text { Cleaning gas piping is a difficult } \\
\text { repair, assume } S=3\end{array}$ & \begin{tabular}{|l|}
$5 \mathrm{E}-07 / \mathrm{h}$ \\
and \\
$3000 \mathrm{~h} / \mathrm{y}$ \\
$\mathrm{O}=2$
\end{tabular} & $\begin{array}{l}\text { Blanchard } \\
1998, \text { no k } \\
\text { factor } \\
\text { assigned }\end{array}$ & $3 \times 2=6$ & $\begin{array}{l}\text { The cleaning task would be to } \\
\text { flush piping with cleaning agent, } \\
\text { keeping moisture out of piping. }\end{array}$ \\
\hline & & $\begin{array}{l}\text { Internal leak } \\
\text { past seat }\end{array}$ & $\begin{array}{l}\text { Seat wear, not } \\
\text { fully seated by } \\
\text { valve operator }\end{array}$ & $\begin{array}{l}\text { Regular sampling } \\
\text { of gas in system for } \\
\text { foreign materials, } \\
\text { check motor current }\end{array}$ & $\begin{array}{l}\text { Minor degradation of } \\
\text { system. Draws on pipe } \\
\text { between V-3 and V-5. }\end{array}$ & $\begin{array}{l}\text { Repair valve next } \\
\text { outage. }\end{array}$ & Hale 2001, MTTR $=8$ h, so $S=2$ & $\begin{array}{l}1 \mathrm{E}-05 / \mathrm{h} \\
3000 \mathrm{~h} / \mathrm{y} \\
\mathrm{O}=4\end{array}$ & $\begin{array}{l}\text { Blanchard } \\
1998, \text { no k } \\
\text { factor } \\
\text { assigned }\end{array}$ & $2 \times 4=8$ & $\begin{array}{l}\text { Leak past the seat is difficult to } \\
\text { detect. }\end{array}$ \\
\hline & & $\begin{array}{l}\text { Internal } \\
\text { rupture }\end{array}$ & $\begin{array}{l}\text { Valve disk failure, } \\
\text { seat mechanical } \\
\text { failure }\end{array}$ & High QA on valve & $\begin{array}{l}\text { Cannot isolate PS-1 from } \\
\text { pressure pulse of DM valve } \\
\text { operation, could fail sensor }\end{array}$ & $\begin{array}{l}\text { Repair valve to regain } \\
\text { system operability. }\end{array}$ & judgment is $\mathrm{S}=2$ & $\begin{array}{l}5 \mathrm{E}-07 / \mathrm{h} \\
3000 \mathrm{~h} / \mathrm{y} \\
\mathrm{O}=2\end{array}$ & $\begin{array}{l}\text { Blanchard } \\
1998, \text { no k } \\
\text { factor } \\
\text { assigned } \\
\end{array}$ & $2 \times 2=4$ & \\
\hline & & External leak & $\begin{array}{l}\text { Stem seal } \\
\text { degradation, valve } \\
\text { body crack }\end{array}$ & $\begin{array}{l}\text { High QA on valve, } \\
\text { periodic inspection } \\
\text { of stem seal }\end{array}$ & $\begin{array}{l}\text { System can operate with a } \\
\text { small vacuum leak. }\end{array}$ & $\begin{array}{l}\text { Repair valve next } \\
\text { outage. }\end{array}$ & $\begin{array}{l}\text { Replacing a valve and returning } \\
\text { the system to service, judgment } \\
\text { is } S=3\end{array}$ & $\begin{array}{l}1 \mathrm{E}-07 / \mathrm{h} \\
3000 \mathrm{~h} / \mathrm{y} \\
\mathrm{O}=2\end{array}$ & $\begin{array}{l}\text { Blanchard } \\
1998, \text { no k } \\
\text { factor } \\
\text { assigned } \\
\end{array}$ & $3 \times 2=6$ & \\
\hline & & $\begin{array}{l}\text { External } \\
\text { rupture }\end{array}$ & $\begin{array}{l}\text { Stem seal failure, } \\
\text { valve body failure }\end{array}$ & $\begin{array}{l}\text { High QA on valve, } \\
\text { periodic inspection } \\
\text { of stem seal }\end{array}$ & $\begin{array}{l}\text { Port cell atmosphere is } \\
\text { drawn into vacuum system. } \\
\text { ITER outage until repaired. }\end{array}$ & $\begin{array}{l}\text { Repair valve to regain } \\
\text { system operability. }\end{array}$ & $\begin{array}{l}\text { Replacing a valve and returning } \\
\text { the system to service, judgment } \\
\text { is } S=3\end{array}$ & $\begin{array}{l}5 \mathrm{E}-09 / \mathrm{h} \\
3000 \mathrm{~h} / \mathrm{y} \\
\mathrm{O}=1\end{array}$ & \begin{tabular}{|l|} 
Blanchard \\
1998, no k \\
factor \\
assigned
\end{tabular} & $3 \times 1=3$ & \\
\hline $\begin{array}{l}\text { Pressure sensor in } \\
\text { vacuum purge line, } \\
\text { PS-2 }\end{array}$ & $\begin{array}{l}\text { Idle while } \\
\text { system is in } \\
\text { standby }\end{array}$ & $\begin{array}{l}\text { Fails to } \\
\text { operate }\end{array}$ & $\begin{array}{l}\text { Open circuit, short } \\
\text { circuit }\end{array}$ & $\begin{array}{l}\text { High QA on sensor, } \\
\text { periodic test }\end{array}$ & $\begin{array}{l}\text { Cannot sense gas pressure if } \\
\text { purging DM valve gas } \\
\text { reservoir. PS-3 can aid } \\
\text { operators, or DM valve can } \\
\text { be fired to clear it out. }\end{array}$ & $\begin{array}{l}\text { Repair sensor next } \\
\text { outage. }\end{array}$ & $\begin{array}{l}\text { Hale 2001, Pressure control } \\
\text { MTTR }=5.6 \text { h, so } S=2\end{array}$ & $\begin{array}{l}1 \mathrm{E}-06 / \mathrm{h} \\
3000 \mathrm{~h} / \mathrm{y} \\
\mathrm{O}=2\end{array}$ & $\begin{array}{l}\text { Cadwallader } \\
1996\end{array}$ & $2 \times 2=4$ & $\begin{array}{l}\text { Many designers have noted they } \\
\text { would have put redundant sensors } \\
\text { into design. Or, resilient sensors } \\
\text { (Beck, 2011). }\end{array}$ \\
\hline
\end{tabular}




\begin{tabular}{|c|c|c|c|c|c|c|c|c|c|c|c|}
\hline Component & $\begin{array}{c}\text { Operational } \\
\text { State }\end{array}$ & Failure Mode & Possible Causes & $\begin{array}{l}\text { Preventive Action } \\
\text { on Possible Causes }\end{array}$ & Consequences & $\begin{array}{c}\text { Corrective or } \\
\text { Preventive Actions on } \\
\text { Consequences }\end{array}$ & Comments & $\begin{array}{l}\text { Failure } \\
\text { rate }\end{array}$ & \begin{tabular}{|c|c|}
$\begin{array}{c}\text { Comment } \\
\text { on failure } \\
\text { rate }\end{array}$ \\
\end{tabular} & $\begin{array}{c}\text { Criticality } \\
\text { Number } \\
\mathrm{S} \cdot \mathrm{O}=\mathrm{C}\end{array}$ & Design comments \\
\hline \multirow[t]{3}{*}{ PS-2, continued } & $\begin{array}{l}\text { Idle while } \\
\text { system is in } \\
\text { standby }\end{array}$ & $\begin{array}{l}\text { Erratic } \\
\text { reading }\end{array}$ & $\begin{array}{l}\text { EM interference, } \\
\text { foreign material } \\
\text { buildup in unit }\end{array}$ & $\begin{array}{l}\text { Shield for EM } \\
\text { energy, specify } \\
\text { clean gas }\end{array}$ & $\begin{array}{l}\text { Cannot track DM valve gas } \\
\text { sweep to vacuum line. PS-3 } \\
\text { could support the valve } \\
\text { purge to vacuum. }\end{array}$ & $\begin{array}{l}\text { Repair sensor next } \\
\text { outage. }\end{array}$ & $\begin{array}{l}\text { Assume } 50 \% \text { of the failure to } \\
\text { operate failure rate, so } 5 \mathrm{E}-07 / \mathrm{h} \\
\text { Hale } 2001 \text {, Pressure control } \\
\text { MTTR }=5.6 \mathrm{~h} \text {, so } \mathrm{S}=2\end{array}$ & $\begin{array}{l}5 \mathrm{E}-07 / \mathrm{h} \\
3000 \mathrm{~h} / \mathrm{y} \\
\mathrm{O}=2\end{array}$ & \begin{tabular}{|l|} 
Analyst \\
judgment
\end{tabular} & $2 \times 2=4$ & \\
\hline & & External leak & $\begin{array}{l}\text { Fitting fault or } \\
\text { crack, sensing line } \\
\text { fault }\end{array}$ & $\begin{array}{l}\text { High QA on parts, } \\
\text { installation. } \\
\text { Periodic inspection }\end{array}$ & $\begin{array}{l}\text { Small leak is drawing air } \\
\text { into vacuum line, wasting } \\
\text { ITER resources on gas } \\
\text { handling. }\end{array}$ & $\begin{array}{l}\text { Repair sensor next } \\
\text { outage. }\end{array}$ & $\begin{array}{l}\text { Assume 1-m sensing line, } \\
\text { Hale 2001, Pressure control } \\
\text { MTTR=5.6 h, so } \mathrm{S}=2\end{array}$ & $\begin{array}{l}1 \mathrm{E}-07 / \mathrm{h} \\
3000 \mathrm{~h} / \mathrm{y} \\
\mathrm{O}=2\end{array}$ & \begin{tabular}{|l} 
Blanchard \\
1998
\end{tabular} & $2 \times 2=4$ & $\begin{array}{l}\text { Gas leak into port cell may not be } \\
\text { easy to detect. }\end{array}$ \\
\hline & & $\begin{array}{l}\text { External } \\
\text { rupture }\end{array}$ & $\begin{array}{l}\text { Fitting failure, } \\
\text { sensing line break }\end{array}$ & $\begin{array}{l}\text { High QA on parts, } \\
\text { installation. } \\
\text { Periodic inspection }\end{array}$ & $\begin{array}{l}\text { PS-2 is failed, system is } \\
\text { drawing air from port cell. } \\
\text { Wasting ITER resources on } \\
\text { gas handling until repaired. }\end{array}$ & $\begin{array}{l}\text { Isolate vacuum line. } \\
\text { Repair sensor as soon as } \\
\text { possible. }\end{array}$ & $\begin{array}{l}\text { Assume 1-m sensing line. } \\
\text { Replace sensor, return system to } \\
\text { service, assume } S=2\end{array}$ & $\begin{array}{l}3.3 \mathrm{E}-09 / \mathrm{h} \\
3000 \mathrm{~h} / \mathrm{y} \\
\mathrm{O}=1\end{array}$ & \begin{tabular}{|l} 
Blanchard \\
1998
\end{tabular} & $2 \times 1=2$ & \\
\hline \multirow[t]{6}{*}{$\begin{array}{l}\text { Gas line isolation } \\
\text { valve, Valve-5 }\end{array}$} & $\begin{array}{l}\text { Normally } \\
\text { closed }\end{array}$ & $\begin{array}{l}\text { Spurious } \\
\text { operation }\end{array}$ & $\begin{array}{l}\text { Command fault, } \\
\text { human error, } \\
\text { electronic noise }\end{array}$ & $\begin{array}{l}\text { Periodic testing, } \\
\text { software QA, noise } \\
\text { shielding }\end{array}$ & $\begin{array}{l}\text { Valve opens, unisolates } \\
\text { Meter-1. }\end{array}$ & $\begin{array}{l}\text { Can operate system with } \\
\text { this failure. Repair valve } \\
\text { to regain system } \\
\text { integrity. }\end{array}$ & Hale $2001, \mathrm{MTTR}=8$ h, so $\mathrm{S}=2$ & $\begin{array}{l}6.18 \mathrm{E}-07 / \mathrm{h} \\
3000 \mathrm{~h} / \mathrm{y} \\
\mathrm{O}=2\end{array}$ & \begin{tabular}{|l|} 
Blanchard \\
1998, \\
Table $2-4 \mathrm{k}$ \\
factor of \\
2.06 \\
\end{tabular} & $2 \times 2=4$ & \\
\hline & & Plugging & $\begin{array}{l}\text { Moisture in system } \\
\text { may create rust } \\
\text { that fouls valve, } \\
\text { foreign material in } \\
\text { system such as } \\
\text { hydrocarbons gum } \\
\text { up valve disk and } \\
\text { seat }\end{array}$ & $\begin{array}{l}\text { Regular sampling } \\
\text { of gas in system for } \\
\text { impurities and } \\
\text { foreign materials, } \\
\text { monitor moisture in } \\
\text { system }\end{array}$ & $\begin{array}{l}\text { Cannot charge the MGI DM } \\
\text { valve closure volume with } \\
\text { appropriate gas pressure, so } \\
\text { DM valve is not optimum } \\
\text { but can function. Longer } \\
\text { than } 3 \text { hours to restore DM } \\
\text { valve. }\end{array}$ & $\begin{array}{l}\text { Can operate system with } \\
\text { this failure. Repair valve } \\
\text { to regain system } \\
\text { integrity. }\end{array}$ & $\begin{array}{l}\text { Cleaning gas piping is a difficult } \\
\text { repair, assume } S=3\end{array}$ & $\begin{array}{l}5 \mathrm{E}-07 / \mathrm{h} \\
\text { and } \\
3000 \mathrm{~h} / \mathrm{y} \\
\mathrm{O}=2\end{array}$ & $\begin{array}{l}\text { Blanchard } \\
1998, \text { no k } \\
\text { factor } \\
\text { assigned }\end{array}$ & $3 \times 2=6$ & $\begin{array}{l}\text { The cleaning task would be to } \\
\text { flush piping with cleaning agent, } \\
\text { keeping moisture out of piping. }\end{array}$ \\
\hline & & $\begin{array}{l}\text { Internal leak } \\
\text { past seat }\end{array}$ & $\begin{array}{l}\text { Seat wear, not } \\
\text { fully seated by } \\
\text { valve operator }\end{array}$ & $\begin{array}{l}\text { Regular sampling } \\
\text { of gas in system for } \\
\text { foreign materials, } \\
\text { check motor current }\end{array}$ & $\begin{array}{l}\text { Minor degradation of } \\
\text { system. }\end{array}$ & $\begin{array}{l}\text { Repair valve next } \\
\text { outage. }\end{array}$ & Hale 2001, MTTR $=8$ h, so $S=2$ & $\begin{array}{l}1 \mathrm{E}-05 / \mathrm{h} \\
3000 \mathrm{~h} / \mathrm{y} \\
\mathrm{O}=4\end{array}$ & \begin{tabular}{|l} 
Blanchard \\
1998, no k \\
factor \\
assigned \\
\end{tabular} & $2 \times 4=8$ & $\begin{array}{l}\text { Leak past the seat is difficult to } \\
\text { detect. }\end{array}$ \\
\hline & & $\begin{array}{l}\text { Internal } \\
\text { rupture }\end{array}$ & $\begin{array}{l}\text { Valve disk failure, } \\
\text { seat mechanical } \\
\text { failure }\end{array}$ & High QA on valve & $\begin{array}{l}\text { Cannot isolate PS-1 from } \\
\text { pressure pulse of DM valve } \\
\text { operation, could fail sensor }\end{array}$ & $\begin{array}{l}\text { Repair valve to regain } \\
\text { system operability. }\end{array}$ & Analyst assumes $\mathrm{S}=2$ & $\begin{array}{l}5 \mathrm{E}-07 / \mathrm{h} \\
3000 \mathrm{~h} / \mathrm{y} \\
\mathrm{O}=2\end{array}$ & \begin{tabular}{|l|} 
Blanchard \\
1998, no k \\
factor \\
assigned \\
\end{tabular} & $2 \times 2=4$ & \\
\hline & & External leak & $\begin{array}{l}\text { Stem seal } \\
\text { degradation, valve } \\
\text { body crack }\end{array}$ & $\begin{array}{l}\text { High QA on valve, } \\
\text { periodic inspection } \\
\text { of stem seal }\end{array}$ & $\begin{array}{l}\text { Wasting gas from the ITER } \\
\text { gas supply. System can } \\
\text { operate with a small leak. }\end{array}$ & $\begin{array}{l}\text { Repair valve next } \\
\text { outage. }\end{array}$ & $\begin{array}{l}\text { Replacing a valve and returning } \\
\text { the system to service, judgment } \\
\text { is } S=3\end{array}$ & $\begin{array}{l}1 \mathrm{E}-07 / \mathrm{h} \\
3000 \mathrm{~h} / \mathrm{y} \\
\mathrm{O}=2\end{array}$ & $\begin{array}{l}\text { Blanchard } \\
1998, \text { no k } \\
\text { factor } \\
\text { assigned } \\
\end{array}$ & $3 \times 2=6$ & $\begin{array}{l}\text { Gas leak into port cell may not be } \\
\text { easy to detect. }\end{array}$ \\
\hline & & $\begin{array}{l}\text { External } \\
\text { rupture }\end{array}$ & $\begin{array}{l}\text { Stem seal failure, } \\
\text { valve body failure }\end{array}$ & $\begin{array}{l}\text { High QA on valve, } \\
\text { periodic inspection } \\
\text { of stem seal }\end{array}$ & $\begin{array}{l}\text { Cannot charge DM valve 1- } \\
\text { liter volume, ITER outage } \\
\text { until repaired. }\end{array}$ & $\begin{array}{l}\text { Repair valve to regain } \\
\text { system operability. }\end{array}$ & $\begin{array}{l}\text { Replacing a valve and returning } \\
\text { the system to service, judgment } \\
\text { is } S=3\end{array}$ & $\begin{array}{l}5 \mathrm{E}-09 / \mathrm{h} \\
3000 \mathrm{~h} / \mathrm{y} \\
\mathrm{O}=1\end{array}$ & \begin{tabular}{|l} 
Blanchard \\
1998, no k \\
factor \\
assigned \\
\end{tabular} & $3 \times 1=3$ & \\
\hline \multirow[t]{2}{*}{$\begin{array}{l}\text { Gas pressure sensor } \\
\text { near vacuum purge } \\
\text { line, PS-3 }\end{array}$} & $\begin{array}{l}\text { Normally } \\
\text { operating }\end{array}$ & $\begin{array}{l}\text { Fails to } \\
\text { operate }\end{array}$ & $\begin{array}{l}\text { Open circuit, short } \\
\text { circuit }\end{array}$ & $\begin{array}{l}\text { High QA on sensor, } \\
\text { periodic test }\end{array}$ & $\begin{array}{l}\text { Cannot charge DM valve } \\
\text { closure volume to spec, DM } \\
\text { valve will not operate } \\
\text { correctly, but will open. }\end{array}$ & $\begin{array}{l}\text { Repair sensor next } \\
\text { outage. }\end{array}$ & $\begin{array}{l}\text { Hale 2001, Pressure control } \\
\text { MTTR=5.6 h, so } S=2\end{array}$ & $\begin{array}{l}1 \mathrm{E}-06 / \mathrm{h} \\
3000 \mathrm{~h} / \mathrm{y} \\
\mathrm{O}=2\end{array}$ & $\begin{array}{l}\text { Cadwallader } \\
1996\end{array}$ & $2 \times 2=4$ & $\begin{array}{l}\text { Failed pressure sensor will be } \\
\text { obvious. Many designers have } \\
\text { noted they would have put } \\
\text { redundant sensors into design. Or, } \\
\text { resilient sensors (Beck, 2011). }\end{array}$ \\
\hline & & $\begin{array}{l}\text { Erratic } \\
\text { reading }\end{array}$ & $\begin{array}{l}\text { EM interference, } \\
\text { foreign material } \\
\text { buildup in unit }\end{array}$ & $\begin{array}{l}\text { Shield for EM } \\
\text { energy, specify } \\
\text { clean gas }\end{array}$ & $\begin{array}{l}\text { Cannot charge DM valve } \\
\text { closure volume to spec, } \\
\text { valve will not operate } \\
\text { correctly, but will open. }\end{array}$ & $\begin{array}{l}\text { Repair sensor next } \\
\text { outage. }\end{array}$ & $\begin{array}{l}\text { Assume } 50 \% \text { of the failure to } \\
\text { operate failure rate, so } 5 \mathrm{E}-07 / \mathrm{h} \\
\text { Hale } 2001 \text {, Pressure control } \\
\text { MTTR }=5.6 \mathrm{~h} \text {, so } \mathrm{S}=2\end{array}$ & $\begin{array}{l}5 \mathrm{E}-07 / \mathrm{h} \\
3000 \mathrm{~h} / \mathrm{y} \\
\mathrm{O}=2\end{array}$ & \begin{tabular}{|l} 
Analyst \\
judgment
\end{tabular} & $2 \times 2=4$ & \\
\hline
\end{tabular}




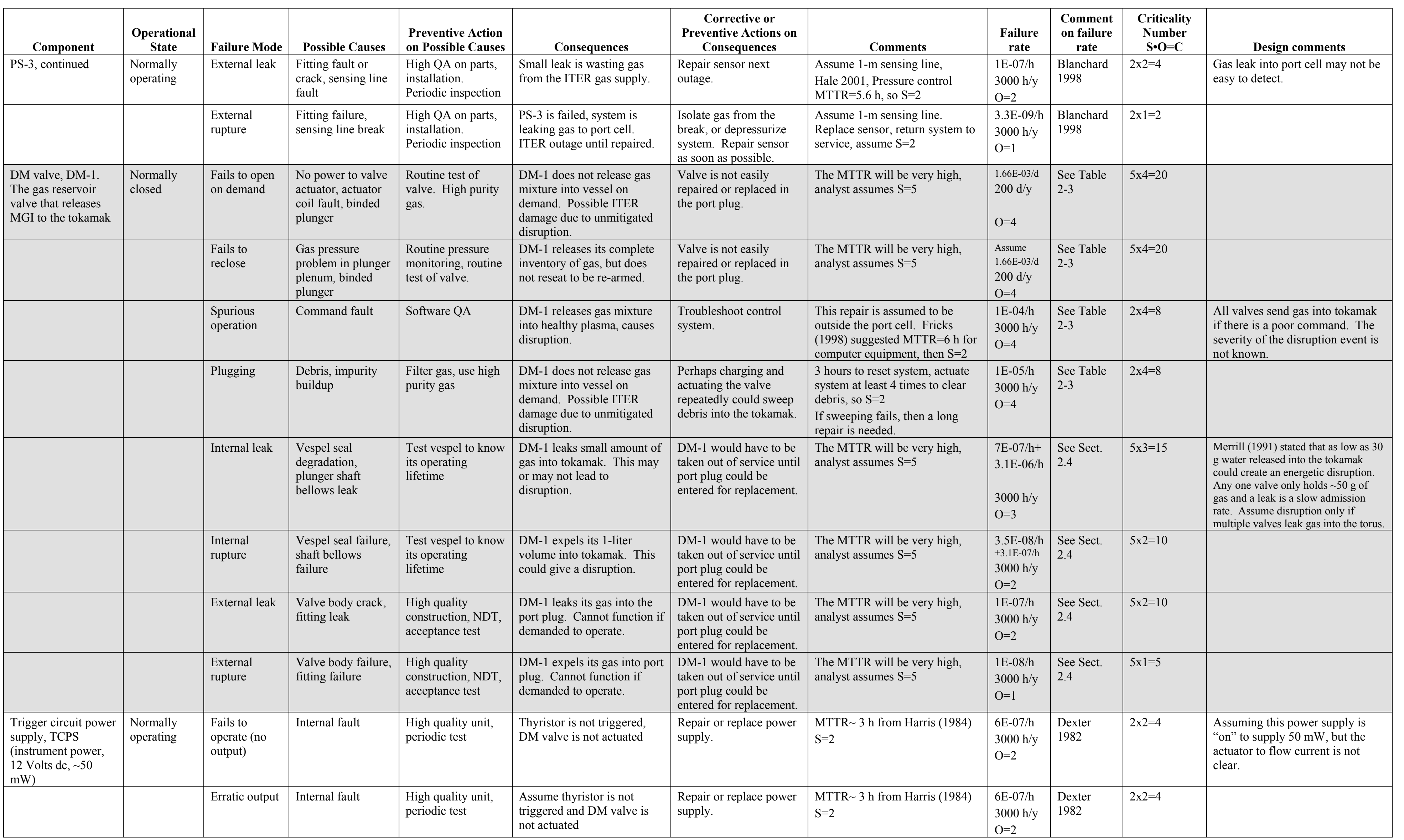




\begin{tabular}{|c|c|c|c|c|c|c|c|c|c|c|c|}
\hline Component & $\begin{array}{c}\text { Operational } \\
\text { State }\end{array}$ & Failure Mode & Possible Causes & \begin{tabular}{|c|} 
Preventive Action \\
on Possible Causes \\
\end{tabular} & Consequences & $\begin{array}{c}\text { Corrective or } \\
\text { Preventive Actions on } \\
\text { Consequences }\end{array}$ & Comments & $\begin{array}{c}\text { Failure } \\
\text { rate }\end{array}$ & $\begin{array}{c}\text { Comment } \\
\text { on failure } \\
\text { rate }\end{array}$ & $\begin{array}{c}\text { Criticality } \\
\text { Number } \\
\mathrm{S} \cdot \mathrm{O}=\mathrm{C}\end{array}$ & Design comments \\
\hline \multirow[t]{2}{*}{$\begin{array}{l}\text { Fiber optic cable for } \\
\text { optical trigger signal, } \\
\text { FOC }\end{array}$} & $\begin{array}{l}\text { Normally } \\
\text { operating }\end{array}$ & Open circuit & $\begin{array}{l}\text { Optic fiber } \\
\text { fracture, } \\
\text { installation error }\end{array}$ & $\begin{array}{l}\text { Test the circuit } \\
\text { periodically since it } \\
\text { is a machine } \\
\text { protection system }\end{array}$ & $\begin{array}{l}\text { No signal to thyristor, so } \\
\text { DM-1 valve is not actuated }\end{array}$ & \begin{tabular}{|l|} 
Success criteria for the \\
system must be defined, \\
perhaps some TM \\
valves $(75 \% ?)$ opening \\
is adequate. \\
\end{tabular} & $\begin{array}{l}\text { Assume } 3 \mathrm{~h} \text { based on Harris } \\
\text { (1984), so } \mathrm{S}=2\end{array}$ & \begin{tabular}{|l|}
$1.1 \mathrm{E}-10 / \mathrm{m}-$ \\
$\mathrm{h}$ \\
$3000 \mathrm{~h} / \mathrm{y}$ \\
$100 \mathrm{~m}$ \\
$\mathrm{O}=1$ \\
\end{tabular} & $\begin{array}{l}\text { Volotinen } \\
1999\end{array}$ & $2 \times 1=2$ & \\
\hline & & $\begin{array}{l}\text { Excessive } \\
\text { signal } \\
\text { attenuation }\end{array}$ & \begin{tabular}{|l} 
Some fibers \\
fractured, \\
installation error
\end{tabular} & $\begin{array}{l}\text { Test the circuit } \\
\text { periodically since it } \\
\text { is a machine } \\
\text { protection system }\end{array}$ & $\begin{array}{l}\text { Assume signal too weak to } \\
\text { actuate thyristor, so DM-1 } \\
\text { valve is not actuated }\end{array}$ & \begin{tabular}{|l|} 
Success criteria for the \\
system must be defined, \\
perhaps some TM \\
valves $(75 \% ?)$ opening \\
is adequate. \\
\end{tabular} & $\begin{array}{l}\text { Assume } 3 \mathrm{~h} \text { based on Harris } \\
\text { (1984), so } \mathrm{S}=2\end{array}$ & \begin{tabular}{|l|}
$1.1 \mathrm{E}-10 / \mathrm{m}-$ \\
$\mathrm{h}$ \\
$3000 \mathrm{~h} / \mathrm{y}$ \\
$100 \mathrm{~m}$ \\
$\mathrm{O}=1$ \\
\end{tabular} & $\begin{array}{l}\text { Volotinen } \\
1999\end{array}$ & $2 \times 1=2$ & \\
\hline \multirow{2}{*}{$\begin{array}{l}\text { High Voltage power } \\
\text { supply, HV Pwr Sup } \\
\text { ( } 1 \text { to } 3 \mathrm{kV} \mathrm{dc,} \\
\text { supplies } 1600 \mathrm{~J} \text { to } \\
\text { cap bank) }\end{array}$} & $\begin{array}{l}\text { Normally } \\
\text { operating at } \\
\text { system } \\
\text { startup }\end{array}$ & $\begin{array}{l}\text { Fails to } \\
\text { operate (no } \\
\text { output) }\end{array}$ & Internal fault & $\begin{array}{l}\text { Test the circuit } \\
\text { periodically since it } \\
\text { is a machine } \\
\text { protection system }\end{array}$ & $\begin{array}{l}\text { No power to charge the } \\
\text { capacitor bank. System is } \\
\text { not armed for operation. }\end{array}$ & $\begin{array}{l}\text { Repair power supply to } \\
\text { regain system } \\
\text { operability. }\end{array}$ & $\begin{array}{l}\text { MTTR } \sim 8 \text { h (Harris, 1984) } \\
\text { S=2 }\end{array}$ & $\begin{array}{l}1 \mathrm{E}-06 / \mathrm{h} \\
3000 \mathrm{~h} / \mathrm{y} \\
\mathrm{O}=2\end{array}$ & $\begin{array}{l}\text { Dexter } \\
1982\end{array}$ & $2 \times 2=4$ & \\
\hline & & Erratic output & Internal fault & $\begin{array}{l}\text { Test the circuit } \\
\text { periodically since it } \\
\text { is a machine } \\
\text { protection system }\end{array}$ & $\begin{array}{l}\text { Erratic power to charge the } \\
\text { capacitor bank, takes longer } \\
\text { to reach } 1600 \mathrm{~J} \text {. System can } \\
\text { operate. }\end{array}$ & $\begin{array}{l}\text { Repair power supply for } \\
\text { full operability }\end{array}$ & $\begin{array}{l}\text { MTTR } \sim 8 \text { h (Harris, 1984) } \\
\text { S=2 }\end{array}$ & $\begin{array}{l}1 \mathrm{E}-06 / \mathrm{h} \\
3000 \mathrm{~h} / \mathrm{y} \\
\mathrm{O}=2\end{array}$ & $\begin{array}{l}\text { Dexter } \\
1982\end{array}$ & $2 \times 2=4$ & \\
\hline \multirow[t]{2}{*}{$\begin{array}{l}\text { High voltage cable in } \\
\text { the port plug, } \mathrm{C}-1\end{array}$} & $\begin{array}{l}\text { Normally } \\
\text { operating }\end{array}$ & Open circuit & $\begin{array}{l}\text { Local overheat, } \\
\text { pinched cable, } \\
\text { insulation } \\
\text { breakdown }\end{array}$ & $\begin{array}{l}\text { Test the circuit } \\
\text { periodically since it } \\
\text { is a machine } \\
\text { protection system }\end{array}$ & $\begin{array}{l}\text { No power to charge the } \\
\text { capacitor bank. System is } \\
\text { not armed for operation. }\end{array}$ & $\begin{array}{l}\text { Repair cable to regain } \\
\text { system operability. }\end{array}$ & $\begin{array}{l}\text { MTTR }=5 \mathrm{~h} \text { (Cadwallader 2001). } \\
\text { But port plug admission is } \\
\text { difficult, assume } S=5\end{array}$ & $\begin{array}{l}9.8 \mathrm{E}-08 / \mathrm{h}- \\
\mathrm{m} \\
30 \mathrm{~m} \\
3000 \mathrm{~h} / \mathrm{y} \\
\mathrm{O}=3\end{array}$ & $\begin{array}{l}\text { Cadwallader } \\
2001, \\
\text { Assume a } \\
\text { cable } k \\
\text { factor of } 10\end{array}$ & $5 \times 3=15$ & $\begin{array}{l}\text { When pressure is different at two ends of a a } \\
\text { cable, gas and moisture can be drawn } \\
\text { throght the cable (Jacobus, 1990). Cable } \\
\text { should be sealed against port plug vacuum. } \\
\mathrm{K} \text { factor of } 10 \text { (see Cadwallader } 2013) \text { is } \\
\text { assumed due to high radiation; assumed } \\
120 \mathrm{C} \text { i design temperature - and no } \\
\text { moisture and little oxygen is benign for } \\
\text { cable insulation (Gillen, 1990). }\end{array}$ \\
\hline & & Short circuit & Insulation failure & $\begin{array}{l}\text { Test cable } \\
\text { insulation } \\
\text { periodically. }\end{array}$ & $\begin{array}{l}\text { No power to charge the } \\
\text { capacitor bank. System is } \\
\text { not armed for operation. } \\
\text { Potential fire. }\end{array}$ & $\begin{array}{l}\text { Repair cable to regain } \\
\text { system operability. }\end{array}$ & $\begin{array}{l}\text { MTTR }=5 \mathrm{~h} \text { (Cadwallader 2001) } \\
\text { But port plug admission is } \\
\text { difficult, assume } \mathrm{S}=5\end{array}$ & \begin{tabular}{|l|}
$9.8 \mathrm{E}-08 / \mathrm{h}-$ \\
$\mathrm{m}$ \\
$30 \mathrm{~m}$ \\
$3000 \mathrm{~h} / \mathrm{y}$ \\
$\mathrm{O}=3$
\end{tabular} & $\begin{array}{l}\text { Assumed } \\
\text { from } \\
\text { Cadwallader } \\
2001, \\
\text { Assume a } \\
\text { cable } \mathrm{k} \\
\text { factor of } 10\end{array}$ & $5 \times 3=15$ & \\
\hline \multirow[t]{2}{*}{$\begin{array}{l}\text { High voltage cable } \\
\text { outside of port plug, } \\
\text { C-2 }\end{array}$} & $\begin{array}{l}\text { Normally } \\
\text { operating }\end{array}$ & Open circuit & $\begin{array}{l}\text { Local overheat, } \\
\text { pinched cable, } \\
\text { moisture intrusion }\end{array}$ & $\begin{array}{l}\text { Test the circuit } \\
\text { periodically since it } \\
\text { is a machine } \\
\text { protection system }\end{array}$ & $\begin{array}{l}\text { No power to charge the } \\
\text { capacitor bank. System is } \\
\text { not armed for operation. }\end{array}$ & $\begin{array}{l}\text { Repair cable to regain } \\
\text { system operability. }\end{array}$ & $\begin{array}{l}\text { MTTR=5 h (Cadwallader 2001) } \\
\mathrm{S}=2\end{array}$ & \begin{tabular}{|l}
$3.6 \mathrm{E}-08 / \mathrm{h}-$ \\
$\mathrm{m}$ \\
$100 \mathrm{~m}$ \\
$3000 \mathrm{~h} / \mathrm{y}$ \\
$\mathrm{O}=3$
\end{tabular} & $\begin{array}{l}\text { Cadwallader } \\
2001, \\
\text { Table } 2-4 \mathrm{k} \\
\text { factor of } 3.7\end{array}$ & $2 \times 3=6$ & $\begin{array}{l}\text { When pressure is different at two } \\
\text { ends of a cable, gas and moisture } \\
\text { can be drawn through the cable } \\
\text { (Jacobus, 1990). Cable should be } \\
\text { sealed against port plug vacuum. } \\
\text { Note this is a mineral insulated } \\
\text { coax cable for radiation resistance. }\end{array}$ \\
\hline & & Short circuit & Insulation failure & $\begin{array}{l}\text { Test cable } \\
\text { insulation } \\
\text { periodically. }\end{array}$ & $\begin{array}{l}\text { No power to charge the } \\
\text { capacitor bank. System is } \\
\text { not armed for operation. } \\
\text { Potential fire. }\end{array}$ & $\begin{array}{l}\text { Repair cable to regain } \\
\text { system operability. }\end{array}$ & $\begin{array}{l}\text { MTTR=5 h (Cadwallader 2001) } \\
\mathrm{S}=2\end{array}$ & \begin{tabular}{|l|}
$3.6 \mathrm{E}-08 \mathrm{~h}-$ \\
$\mathrm{m}$ \\
$100 \mathrm{~m}$ \\
$3000 \mathrm{~h} / \mathrm{y}$ \\
$\mathrm{O}=3$
\end{tabular} & $\begin{array}{l}\text { Assumed } \\
\text { from } \\
\text { Cadwallader } \\
2001 \text {, Table } \\
2-4 \mathrm{k} \text { factor } \\
\text { of } 3.7\end{array}$ & $2 \times 3=6$ & \\
\hline $\begin{array}{l}\text { Instrument power } \\
\text { wire, } \mathrm{W}\end{array}$ & $\begin{array}{l}\text { Normally } \\
\text { operating }\end{array}$ & Open circuit & $\begin{array}{l}\text { Local overheat, } \\
\text { pinched cable, } \\
\text { moisture intrusion }\end{array}$ & $\begin{array}{l}\text { Test circuit } \\
\text { periodically. }\end{array}$ & $\begin{array}{l}\text { No power to PLC. System is } \\
\text { not under active control, not } \\
\text { armed for operation. }\end{array}$ & $\begin{array}{l}\text { Repair wire to regain } \\
\text { system operability }\end{array}$ & $\begin{array}{l}\text { MTTR }=3 \mathrm{~h} \text { (Harris, 1984) } \\
\mathrm{S}=2 \text {. Assume } 50 \% \text { open and } \\
50 \% \text { short circuit. }\end{array}$ & \begin{tabular}{|l|}
$7.7 \mathrm{E}-09 / \mathrm{h}-$ \\
$\mathrm{m}$ \\
$30 \mathrm{~m}$ \\
$3000 \mathrm{~h} / \mathrm{y}$ \\
$\mathrm{O}=1$
\end{tabular} & Harris 1984 & $2 \times 1=2$ & \\
\hline
\end{tabular}




\begin{tabular}{|c|c|c|c|c|c|c|c|c|c|c|c|}
\hline Component & $\begin{array}{c}\text { Operational } \\
\text { State }\end{array}$ & Failure Mode & Possible Causes & $\begin{array}{c}\text { Preventive Action } \\
\text { on Possible Causes }\end{array}$ & Consequences & $\begin{array}{c}\text { Corrective or } \\
\text { Preventive Actions on } \\
\text { Consequences } \\
\end{array}$ & Comments & $\begin{array}{c}\text { Failure } \\
\text { rate }\end{array}$ & $\begin{array}{c}\begin{array}{c}\text { Comment } \\
\text { on failure } \\
\text { rate }\end{array} \\
\end{array}$ & $\begin{array}{c}\text { Criticality } \\
\text { Number } \\
\mathrm{S} \cdot \mathbf{O}=\mathrm{C}\end{array}$ & Design comments \\
\hline W, continued & $\begin{array}{l}\text { Normally } \\
\text { operating }\end{array}$ & Short circuit & Insulation failure & $\begin{array}{l}\text { Test circuit } \\
\text { periodically. }\end{array}$ & $\begin{array}{l}\text { No power to PLC, potential } \\
\text { fire. }\end{array}$ & $\begin{array}{l}\text { Repair wire to regain } \\
\text { system operability }\end{array}$ & $\begin{array}{l}\text { MTTR }=3 \text { h (Harris, 1984), this } \\
\text { would be } S=2 \text {. Assume } 50 \% \\
\text { open and } 50 \% \text { short circuit. }\end{array}$ & $\begin{array}{l}7.7 \mathrm{E}-09 / \mathrm{h}- \\
\mathrm{m} \\
30 \mathrm{~m} \\
3000 \mathrm{~h} / \mathrm{y} \\
\mathrm{O}=1\end{array}$ & Harris 1984 & $2 \times 1=2$ & \\
\hline \multirow[t]{4}{*}{$\begin{array}{l}\text { Capacitor bank, } \\
C_{\text {Bank }}(400 \\
\text { microFarads, and } \\
1650 \text { V) }\end{array}$} & $\begin{array}{l}\text { Normally } \\
\text { charged }\end{array}$ & Open circuit & $\begin{array}{l}\text { Voltage ripple or } \\
\text { transient voltage, } \\
\text { lead or terminal } \\
\text { overheats and fails } \\
\text { open }\end{array}$ & $\begin{array}{l}\text { Test circuit } \\
\text { periodically. }\end{array}$ & $\begin{array}{l}\text { Capacitor does not deliver } \\
\text { rated energy to triggering } \\
\text { system when demanded. } \\
\text { DM-1 valve does not open. }\end{array}$ & Replace capacitor & $\begin{array}{l}\text { Fields (2012) gives } 6 \% \text { open ckt. } \\
\text { Assume MTTR }<24 \text { h, so } S=2\end{array}$ & $\begin{array}{l}3.1 \mathrm{E}-08 / \mathrm{h} \\
3000 \mathrm{~h} / \mathrm{y} \\
\mathrm{O}=1\end{array}$ & $\begin{array}{l}\text { Denson } \\
1996, \mathrm{p} 2- \\
1, \\
5.2 \mathrm{E}-07 / \mathrm{h}\end{array}$ & $2 \times 1=2$ & $\begin{array}{l}\text { Assumed ceramic capacitor since } \\
\text { these are reputed to be less } \\
\text { sensitive to radiation, but } \\
\text { electrolytic capacitor may be } \\
\text { needed for the } 400 \mu \mathrm{F} \text {. }\end{array}$ \\
\hline & & Drift & $\begin{array}{l}\text { High temperature, } \\
\text { foreign material } \\
\text { intrusion }\end{array}$ & $\begin{array}{l}\text { Test circuit } \\
\text { periodically. }\end{array}$ & $\begin{array}{l}\text { Capacitor does not deliver } \\
\text { rated energy to triggering } \\
\text { system when demanded. } \\
\text { DM-1 valve does not open. }\end{array}$ & $\begin{array}{l}\text { Repair or replace } \\
\text { capacitor }\end{array}$ & $\begin{array}{l}\text { Fields (2012) gives } 62.6 \% \text { drift. } \\
\text { Assume MTTR }<24 \text { h, so } S=2\end{array}$ & $\begin{array}{l}3.3 \mathrm{E}-07 / \mathrm{h} \\
3000 \mathrm{~h} / \mathrm{y} \\
\mathrm{O}=2\end{array}$ & $\begin{array}{l}\text { Denson } \\
1996, \mathrm{p} 2- \\
1, \\
5.2 \mathrm{E}-07 / \mathrm{h} \\
\end{array}$ & $2 \times 2=4$ & \\
\hline & & $\begin{array}{l}\text { Capacitance } \\
\text { change }\end{array}$ & $\begin{array}{l}\text { Voids in ceramic, } \\
\text { foreign material } \\
\text { intrusion, cracks in } \\
\text { ceramic, high } \\
\text { temperature }\end{array}$ & $\begin{array}{l}\text { High quality in } \\
\text { component } \\
\text { manufacture, } \\
\text { testing }\end{array}$ & $\begin{array}{l}\text { Capacitor does not deliver } \\
\text { rated energy to triggering } \\
\text { system when demanded. } \\
\text { DM-1 valve does not open. }\end{array}$ & $\begin{array}{l}\text { Repair or replace } \\
\text { capacitor }\end{array}$ & $\begin{array}{l}\text { Fields (2012) gives } 4.6 \% \text { for } \\
\text { change in capacitance failure } \\
\text { mode. Assume MTTR }<24 \mathrm{~h} \text {, so } \\
\mathrm{S}=2\end{array}$ & $\begin{array}{l}2.4 \mathrm{E}-08 / \mathrm{h} \\
3000 \mathrm{~h} / \mathrm{y} \\
\mathrm{O}=1\end{array}$ & $\begin{array}{l}\text { Denson } \\
1996, \mathrm{p} 2- \\
1, \\
5.2 \mathrm{E}-07 / \mathrm{h}\end{array}$ & $2 \times 1=2$ & \\
\hline & & Arc/fire & $\begin{array}{l}\text { Voltage arc over at } \\
\text { terminals }\end{array}$ & $\begin{array}{l}\text { Good terminal } \\
\text { insulation }\end{array}$ & $\begin{array}{l}\text { Capacitor cannot deliver } \\
\text { rated energy. ITER } \\
\text { downtime due to fire. }\end{array}$ & Replace capacitor & $\begin{array}{l}\text { Assumption based on } \\
\text { Cadwallader (2001) is } 1 \% \text { of } \\
\text { failure rate is the fire mode. } \\
\text { Assume MTTR for a small fire is } \\
<1 \text { week, } S=3\end{array}$ & $\begin{array}{l}5.2 \mathrm{E}-09 / \mathrm{h} \\
3000 \mathrm{~h} / \mathrm{y} \\
\mathrm{O}=1\end{array}$ & $\begin{array}{l}\text { Denson } \\
1996, \mathrm{p} 2- \\
1, \\
5.2 \mathrm{E}-07 / \mathrm{h}\end{array}$ & $3 \times 1=3$ & \\
\hline \multirow[t]{3}{*}{$\begin{array}{l}\text { Thyristor, } \mathrm{T}_{1} \text { (power- } \\
\text { gating unit), off until } \\
\text { actuation signal to } \\
\text { fire }\end{array}$} & $\begin{array}{l}\text { Thyristor is } \\
\text { in standby to } \\
\text { operate }\end{array}$ & $\begin{array}{l}\text { Fails off (fails } \\
\text { to respond to } \\
\text { commands) }\end{array}$ & Internal failure & $\begin{array}{l}\text { Use high quality } \\
\text { parts, perform } \\
\text { periodic testing }\end{array}$ & $\begin{array}{l}\text { Cannot reset (re-arm) system } \\
\text { for protection, thyristor does } \\
\text { not allow current flow }\end{array}$ & Replace unit. & $\begin{array}{l}\text { Hale (2001) gave an MTTR=16 } \\
\mathrm{h} \text { for rectifiers. Assume } \mathrm{S}=2 \text {. } \\
\text { Fields ( } 2012 \text { ) gives } 90 \% \text { for fails } \\
\text { off failure mode. }\end{array}$ & $\begin{array}{l}1 \mathrm{E}-06 / \mathrm{h} \\
200 \mathrm{~d} / \mathrm{y} \\
3 \mathrm{~h} / \mathrm{d} \\
\mathrm{O}=2\end{array}$ & $\begin{array}{l}\text { Denson } \\
1996, \text { p.2- } \\
218\end{array}$ & $2 \times 2=4$ & \\
\hline & & $\begin{array}{l}\text { Fails on } \\
\text { demand }\end{array}$ & Internal failure & $\begin{array}{l}\text { Use high quality } \\
\text { parts, perform } \\
\text { periodic testing }\end{array}$ & $\begin{array}{l}\text { Thyristor does not flow } \\
\text { power to the DM-1 valve }\end{array}$ & Repair or replace unit. & $\begin{array}{l}\text { Hale (2001) gave an MTTR }=16 \\
\text { h for rectifiers. Assume } S=2 \text {. }\end{array}$ & $\begin{array}{l}3.215 \mathrm{E}-04 / \mathrm{d} \\
200 \mathrm{~d} / \mathrm{y} \\
\mathrm{O}=4\end{array}$ & $\begin{array}{l}\text { See Sect. } \\
2.4\end{array}$ & $2 \times 4=8$ & \\
\hline & & Fails on & Internal failure & $\begin{array}{l}\text { Use high quality } \\
\text { parts, perform } \\
\text { periodic testing }\end{array}$ & $\begin{array}{l}\text { Cannot reset (re-arm) system } \\
\text { for protection, thyristor } \\
\text { keeps flowing current to DM } \\
\text { valve coil. }\end{array}$ & Replace unit. & $\begin{array}{l}\text { Hale (2001) gave an MTTR }=16 \\
\mathrm{~h} \text { for rectifiers. Assume } \mathrm{S}=2 \text {. } \\
\text { Fields (2012) gives } 10 \% \text { for fails } \\
\text { on failure mode. }\end{array}$ & $\begin{array}{l}1.14 \mathrm{E}-07 / \mathrm{h} \\
200 \mathrm{~d} / \mathrm{y} \\
3 \mathrm{~h} / \mathrm{d} \\
\mathrm{O}=1\end{array}$ & $\begin{array}{l}\text { Denson } \\
1996, \text { p.2- } \\
218\end{array}$ & $2 \times 1=2$ & \\
\hline \multirow[t]{2}{*}{$\begin{array}{l}\text { Switch, } \mathrm{S}_{1} \\
\text { circuit safing switch }\end{array}$} & $\begin{array}{l}\text { Normally } \\
\text { open in } \\
\text { operation }\end{array}$ & Fails closed & $\begin{array}{l}\text { Command fault, } \\
\text { mechanical failure }\end{array}$ & $\begin{array}{l}\text { Use high quality } \\
\text { parts, perform } \\
\text { periodic testing }\end{array}$ & $\begin{array}{l}\text { Capacitor bank flows energy } \\
\text { only to triggering circuit, } \\
\text { expect overheat damage to } \\
\text { circuit. }\end{array}$ & Repair damage to circuit & $\begin{array}{l}\text { Harris (1984) gives } 1.8 \mathrm{~h} \text { for } \\
\text { power switch repair. Assume } \\
\mathrm{S}=3 \text { for circuit repair. }\end{array}$ & $\begin{array}{l}3.9 \mathrm{E}-07 / \mathrm{h} \\
3000 \mathrm{~h} / \mathrm{y} \\
\mathrm{O}=2\end{array}$ & \begin{tabular}{|l} 
Dexter \\
1982 \\
$7.7 \mathrm{E}-08 / \mathrm{h}$, \\
5 from \\
Table 2-4 \\
\end{tabular} & $3 \times 2=6$ & \\
\hline & & $\begin{array}{l}\text { Fails to } \\
\text { operate }\end{array}$ & Mechanical failure & $\begin{array}{l}\text { Use high quality } \\
\text { parts, perform } \\
\text { periodic testing }\end{array}$ & $\begin{array}{l}\text { Cannot properly 'safe' the } \\
\text { system for maintenance or } \\
\text { inspection }\end{array}$ & Replace or repair switch & $\begin{array}{l}\text { Harris (1984) gives } 1.8 \mathrm{~h} \text { for } \\
\text { power switch repair. Assume } \\
\mathrm{S}=2 .\end{array}$ & $\begin{array}{l}5 \mathrm{E}-05 / \mathrm{d} \\
200 \mathrm{~d} / \mathrm{y} \\
\mathrm{O}=3\end{array}$ & $\begin{array}{l}\text { Dexter } \\
1982 \\
1 \mathrm{E}-05 / \mathrm{d}, \\
5 \text { from } \\
\text { Table 2-4 }\end{array}$ & $2 \times 3=6$ & \\
\hline
\end{tabular}




\begin{tabular}{|c|c|c|c|c|c|c|c|c|c|c|c|}
\hline Component & $\begin{array}{c}\text { Operational } \\
\text { State }\end{array}$ & Failure Mode & Possible Causes & $\begin{array}{l}\text { Preventive Action } \\
\text { on Possible Causes }\end{array}$ & Consequences & \begin{tabular}{|c|} 
Corrective or \\
Preventive Actions on \\
Consequences
\end{tabular} & Comments & $\begin{array}{l}\text { Failure } \\
\text { rate }\end{array}$ & $\begin{array}{l}\text { Comment } \\
\text { on failure } \\
\text { rate }\end{array}$ & $\begin{array}{c}\text { Criticality } \\
\text { Number } \\
\mathrm{S} \cdot \mathrm{O}=\mathrm{C}\end{array}$ & Design comments \\
\hline \multirow[t]{2}{*}{$\begin{array}{l}\text { Switch, } S_{2} \\
\text { operates with Switch } \\
4 \text { for thyristor reset }\end{array}$} & $\begin{array}{l}\text { Normally } \\
\text { closed in } \\
\text { operation }\end{array}$ & Fails open & $\begin{array}{l}\text { Command fault, } \\
\text { mechanical failure }\end{array}$ & $\begin{array}{l}\text { Use high quality } \\
\text { parts, perform } \\
\text { periodic testing }\end{array}$ & $\begin{array}{l}\text { Cannot keep capacitor bank } \\
\text { fully charged from the HV } \\
\text { power supply. DM-1 valve } \\
\text { may not open properly if cap } \\
\text { bank energy is low. }\end{array}$ & $\begin{array}{l}\text { Repair or replace switch } \\
\text { S-2 }\end{array}$ & $\begin{array}{l}\text { Harris (1984) gives } 1.8 \mathrm{~h} \text { for } \\
\text { power switch repair. Assume } \\
\mathrm{S}=2 \text {. }\end{array}$ & $\begin{array}{l}3.9 \mathrm{E}-07 / \mathrm{h} \\
3000 \mathrm{~h} / \mathrm{y} \\
\mathrm{O}=2\end{array}$ & \begin{tabular}{|l|} 
Dexter \\
1982 \\
$7.7 \mathrm{E}-08 / \mathrm{h}$, \\
5 from \\
Table 2-4 \\
\end{tabular} & $2 \times 2=4$ & \\
\hline & & $\begin{array}{l}\text { Fails to } \\
\text { operate }\end{array}$ & Mechanical failure & $\begin{array}{l}\text { Use high quality } \\
\text { parts, perform } \\
\text { periodic testing }\end{array}$ & $\begin{array}{l}\text { Cannot reset thyristor to re- } \\
\text { arm system. }\end{array}$ & $\begin{array}{l}\text { Repair or replace switch } \\
\text { S-2 }\end{array}$ & $\begin{array}{l}\text { Harris (1984) gives } 1.8 \mathrm{~h} \text { for } \\
\text { power switch repair. Assume } \\
\mathrm{S}=2 .\end{array}$ & $\begin{array}{l}5 \mathrm{E}-05 / \mathrm{d} \\
200 \mathrm{~d} / \mathrm{y} \\
\mathrm{O}=3\end{array}$ & \begin{tabular}{|l} 
Dexter \\
1982 \\
$1 \mathrm{E}-05 / \mathrm{d}$, \\
5 from \\
Table 2-4 \\
\end{tabular} & $2 \times 3=6$ & \\
\hline \multirow[t]{2}{*}{$\begin{array}{l}\text { Switch, } \mathrm{S}_{3} \\
\mathrm{HV} \text { power supply } \\
\text { isolation switch }\end{array}$} & $\begin{array}{l}\text { Normally } \\
\text { closed in } \\
\text { operation }\end{array}$ & Fails open & $\begin{array}{l}\text { Command fault, } \\
\text { mechanical failure }\end{array}$ & $\begin{array}{l}\text { Use high quality } \\
\text { parts, perform } \\
\text { periodic testing }\end{array}$ & $\begin{array}{l}\text { Cannot keep capacitor bank } \\
\text { fully charged from the HV } \\
\text { power supply. DM-1 valve } \\
\text { may not open properly if cap } \\
\text { bank energy is low. }\end{array}$ & $\begin{array}{l}\text { Repair or replace switch } \\
\text { S-3 }\end{array}$ & $\begin{array}{l}\text { Harris (1984) gives } 1.8 \mathrm{~h} \text { for } \\
\text { power switch repair. Assume } \\
\mathrm{S}=2 .\end{array}$ & $\begin{array}{l}3.9 \mathrm{E}-07 / \mathrm{h} \\
3000 \mathrm{~h} / \mathrm{y} \\
\mathrm{O}=2\end{array}$ & $\begin{array}{l}\text { Dexter } \\
1982 \\
7.7 \mathrm{E}-08 / \mathrm{h} \\
5 \text { from } \\
\text { Table } 2-4\end{array}$ & $2 \times 2=4$ & \\
\hline & & $\begin{array}{l}\text { Fails to } \\
\text { operate }\end{array}$ & Mechanical failure & $\begin{array}{l}\text { Use high quality } \\
\text { parts, perform } \\
\text { periodic testing }\end{array}$ & $\begin{array}{l}\text { Cannot isolate high voltage } \\
\text { power supply for safety, or } \\
\text { for test, maintenance, and } \\
\text { inspection }\end{array}$ & $\begin{array}{l}\text { Repair or replace switch } \\
\text { S-3 }\end{array}$ & $\begin{array}{l}\text { Harris }(1984) \text { gives } 1.8 \mathrm{~h} \text { for } \\
\text { power switch repair. Assume } \\
\mathrm{S}=2 .\end{array}$ & $\begin{array}{l}5 \mathrm{E}-05 / \mathrm{d} \\
200 \mathrm{~d} / \mathrm{y} \\
\mathrm{O}=3\end{array}$ & \begin{tabular}{|l} 
Dexter \\
1982 \\
$1 \mathrm{E}-05 / \mathrm{d}$, \\
5 from \\
Table 2-4 \\
\end{tabular} & $2 \times 3=6$ & \\
\hline \multirow[t]{2}{*}{$\begin{array}{l}\text { Switch, } \mathrm{S}_{4} \\
\text { thyristor reset switch } \\
\text { after an actuation }\end{array}$} & $\begin{array}{l}\text { Normally } \\
\text { open in } \\
\text { operation }\end{array}$ & Fails closed & $\begin{array}{l}\text { Command fault, } \\
\text { mechanical failure }\end{array}$ & $\begin{array}{l}\text { Use high quality } \\
\text { parts, perform } \\
\text { periodic testing }\end{array}$ & $\begin{array}{l}\text { Capacitor bank discharges } \\
\text { through the resistor R-1, } \\
\text { system cannot actuate valve } \\
\text { DM-1 }\end{array}$ & $\begin{array}{l}\text { Repair or replace switch } \\
\text { S-4 }\end{array}$ & $\begin{array}{l}\text { Harris }(1984) \text { gives } 1.8 \mathrm{~h} \text { for } \\
\text { power switch repair. Assume } \\
\mathrm{S}=2 \text {. }\end{array}$ & $\begin{array}{l}3.9 \mathrm{E}-07 / \mathrm{h} \\
3000 \mathrm{~h} / \mathrm{y} \\
\mathrm{O}=2\end{array}$ & \begin{tabular}{|l} 
Dexter \\
1982 \\
$7.7 \mathrm{E}-08 / \mathrm{h}$, \\
5 from \\
Table $2-4$ \\
\end{tabular} & $2 \times 2=4$ & \\
\hline & & $\begin{array}{l}\text { Fails to } \\
\text { operate }\end{array}$ & Mechanical failure & $\begin{array}{l}\text { Use high quality } \\
\text { parts, perform } \\
\text { periodic testing }\end{array}$ & $\begin{array}{l}\text { Cannot reset thyristor to re- } \\
\text { arm system. }\end{array}$ & $\begin{array}{l}\text { Repair or replace switch } \\
\text { S-4 }\end{array}$ & $\begin{array}{l}\text { Harris (1984) gives } 1.8 \mathrm{~h} \text { for } \\
\text { power switch repair. Assume } \\
\mathrm{S}=2 \text {. }\end{array}$ & $\begin{array}{l}5 \mathrm{E}-05 / \mathrm{d} \\
200 \mathrm{~d} / \mathrm{y} \\
\mathrm{O}=3\end{array}$ & \begin{tabular}{|l} 
Dexter \\
1982 \\
$1 \mathrm{E}-05 / \mathrm{d}$, \\
5 from \\
Table 2-4 \\
\end{tabular} & $2 \times 3=6$ & \\
\hline \multirow[t]{2}{*}{$\begin{array}{l}\text { Switch control, PLC } \\
\text { (assume this is a } \\
\text { programmable logic } \\
\text { controller, PLC) for } \\
\text { S-1, S-2, S-4 }\end{array}$} & $\begin{array}{l}\text { Operating } \\
\text { during } \\
\text { system } \\
\text { operation }\end{array}$ & Fail to operate & $\begin{array}{l}\text { Processor failure, } \\
\text { signal failure }\end{array}$ & Routine test of PLC & $\begin{array}{l}\text { System switches will not } \\
\text { receive signals to change } \\
\text { position, cannot arm or re- } \\
\text { arm system for operation. }\end{array}$ & $\begin{array}{l}\text { Success criteria, perhaps } \\
\text { DMS can function with } \\
\text { one TM valve out of } \\
\text { operation. }\end{array}$ & $\begin{array}{l}\text { Paula (1993) gave } 0.011 / \text { year as } \\
\text { a PLC failure rate, or } 1.3 \mathrm{E}-06 / \mathrm{h} \text {. } \\
\text { Harris (1984) gave an MTTR } \\
\text { upper bound as } 13.8 \mathrm{~h} . \mathrm{S}=2\end{array}$ & $\begin{array}{l}1.3 \mathrm{E}-06 / \mathrm{h} \\
1.25 \\
3000 \mathrm{~h} / \mathrm{y} \\
\mathrm{O}=2\end{array}$ & $\begin{array}{l}\text { Paula } 1993 \\
1.25 \text { from } \\
\text { Table } 2-4\end{array}$ & $2 \times 2=4$ & $\begin{array}{l}\text { Hourtoule (2005) tested some } \\
\text { PLCs for magnetic field } \\
\text { susceptibility, and PLC internal } \\
\text { component limits ranged from } 25 \\
\text { to } 50 \mathrm{mT} \text {. The PLC will need to } \\
\text { be shielded in the port cell. }\end{array}$ \\
\hline & & $\begin{array}{l}\text { Erratic } \\
\text { operation }\end{array}$ & $\begin{array}{l}\text { Intermittent circuit } \\
\text { for signal, } \\
\text { processor fault }\end{array}$ & Routine test of PLC & $\begin{array}{l}\text { System switches may } \\
\text { receive signals to change } \\
\text { position, If S-1 closes, cap } \\
\text { bank discharges into ckt. If } \\
\text { S-4 closed, cap bank } \\
\text { discharges into R-1. }\end{array}$ & Repair or replace PLC & $\begin{array}{l}\text { Paula (1993) gave } 0.011 / \text { year as } \\
\text { a PLC failure rate, or } 1.3 \mathrm{E}-06 / \mathrm{h} \text {. } \\
\text { Harris (1984) gave an MTTR } \\
\text { upper bound as } 13.8 \mathrm{~h} \text {. For } \\
\text { benign failure, } \mathrm{S}=2\end{array}$ & $\begin{array}{l}1.3 \mathrm{E}-06 / \mathrm{h} \\
1.25 \\
3000 \mathrm{~h} / \mathrm{y} \\
\mathrm{O}=2\end{array}$ & $\begin{array}{l}\text { Paula } 1993 \\
1.25 \text { from } \\
\text { Table 2-4 }\end{array}$ & $2 \times 2=4$ & $\begin{array}{l}\text { PLC could send signals that } \\
\text { damage the trigger electronic } \\
\text { system. }\end{array}$ \\
\hline $\begin{array}{l}\text { Resistor, } R_{1} \text {, } \\
\text { dissipates energy in } \\
\text { circuit after actuation }\end{array}$ & $\begin{array}{l}\text { Standby for } \\
\text { current flow }\end{array}$ & Open circuit & Resistor overheat & $\begin{array}{l}\text { Specify high } \\
\text { quality resistor }\end{array}$ & $\begin{array}{l}\text { Energy in circuit from an } \\
\text { actuation is not dissipated in } \\
\text { resistor, energy could } \\
\text { damage the rest of the circuit }\end{array}$ & Replace resistor & $\begin{array}{l}\text { Fields (2012) gives } 75 \% \text { for open } \\
\text { circuit failure mode. Assume } \\
\mathrm{S}=3 \text { for circuit repair. }\end{array}$ & $\begin{array}{l}3.8 \mathrm{E}-08 / \mathrm{h} \\
3000 \mathrm{~h} / \mathrm{y} \\
\mathrm{O}=1\end{array}$ & \begin{tabular}{|l} 
Denson \\
$1996, \mathrm{p} 2-$ \\
218 \\
$4 \mathrm{E}-08 / \mathrm{h}$ \\
1.25 from \\
Table 2-4 \\
\end{tabular} & $3 \times 1=3$ & $\begin{array}{l}\text { Assuming wirewound power } \\
\text { resistor. }\end{array}$ \\
\hline
\end{tabular}




\begin{tabular}{|c|c|c|c|c|c|c|c|c|c|c|c|}
\hline Component & $\begin{array}{c}\text { Operational } \\
\text { State }\end{array}$ & Failure Mode & Possible Causes & $\begin{array}{l}\text { Preventive Action } \\
\text { on Possible Causes }\end{array}$ & Consequences & $\begin{array}{c}\text { Corrective or } \\
\text { Preventive Actions on } \\
\text { Consequences }\end{array}$ & Comments & $\begin{array}{l}\text { Failure } \\
\text { rate }\end{array}$ & $\begin{array}{l}\text { Comment } \\
\text { on failure } \\
\text { rate }\end{array}$ & $\begin{array}{c}\text { Criticality } \\
\text { Number } \\
\mathrm{S} \cdot \mathrm{O}=\mathrm{C}\end{array}$ & Design comments \\
\hline \multirow[t]{3}{*}{$\mathrm{R}_{1}$, continued } & $\begin{array}{l}\text { Standby for } \\
\text { current flow }\end{array}$ & \begin{tabular}{|l|l} 
Drift & \\
\end{tabular} & $\begin{array}{l}\text { Too many heatup } \\
\text { and cooldown } \\
\text { cycles. }\end{array}$ & $\begin{array}{l}\text { Specify margin in } \\
\text { resistor cycles }\end{array}$ & $\begin{array}{l}\text { Energy in circuit from an } \\
\text { actuation is slow to dissipate } \\
\text { in resistor, take more than } 3 \\
\text { hours to reset the system. }\end{array}$ & \begin{tabular}{|l|} 
Replace resistor \\
\end{tabular} & $\begin{array}{l}\text { Fields (2012) gives } 10 \% \text { for drift } \\
\text { failure mode. Assume } \mathrm{S}=2 \text { for } \\
\text { resistor replacement. }\end{array}$ & $\begin{array}{l}5 \mathrm{E}-09 / \mathrm{h} \\
3000 \mathrm{~h} / \mathrm{y} \\
\mathrm{O}=1\end{array}$ & \begin{tabular}{|l|} 
Denson \\
$1996, \mathrm{p} 2-$ \\
218 \\
$4 \mathrm{E}-08 / \mathrm{h}$ \\
1.25 from \\
Table 2-4 \\
\end{tabular} & $2 \times 1=2$ & \\
\hline & & $\begin{array}{l}\text { Mechanical } \\
\text { failure }\end{array}$ & $\begin{array}{l}\text { Resistor impacted } \\
\text { or struck, } \\
\text { debonding }\end{array}$ & $\begin{array}{l}\text { Protect resistor in a } \\
\text { cabinet or } \\
\text { enclosure, specify } \\
\text { high quality resistor }\end{array}$ & $\begin{array}{l}\text { Energy in circuit from an } \\
\text { actuation is not dissipated in } \\
\text { resistor, energy could } \\
\text { damage the rest of the circuit }\end{array}$ & Replace resistor & $\begin{array}{l}\text { Fields (2012) gives } 10 \% \text { for } \\
\text { mechanical failure. Assume } \mathrm{S}=3 \\
\text { for circuit repair. }\end{array}$ & $\begin{array}{l}5 \mathrm{E}-09 / \mathrm{h} \\
3000 \mathrm{~h} / \mathrm{y} \\
\mathrm{O}=1\end{array}$ & $\begin{array}{l}\text { Denson } \\
1996, \text { p2- } \\
218 \\
4 \mathrm{E}-08 / \mathrm{h} \\
1.25 \text { from } \\
\text { Table 2-4 }\end{array}$ & $3 \times 1=3$ & \\
\hline & & Short circuit & Resistor overheat & $\begin{array}{l}\text { Specify high } \\
\text { quality resistor }\end{array}$ & $\begin{array}{l}\text { Energy in circuit from an } \\
\text { actuation is quickly } \\
\text { dissipated in resistor, the } \\
\text { energy release will damage } \\
\text { the area surrounding the rest } \\
\text { of the circuit }\end{array}$ & Replace resistor & $\begin{array}{l}\text { Fields (2012) gives 5\% for } \\
\text { shorted failure mode. Assume } \\
\text { S=3 for cleanup and resistor } \\
\text { replacement }\end{array}$ & $\begin{array}{l}2.5 \mathrm{E}-09 / \mathrm{h} \\
3000 \mathrm{~h} / \mathrm{y} \\
\mathrm{O}=1\end{array}$ & $\begin{array}{l}\text { Denson } \\
1996, \text { p2- } \\
218 \\
4 \mathrm{E}-08 / \mathrm{h} \\
1.25 \text { from } \\
\text { Table 2-4 } \\
\end{array}$ & $3 \times 1=3$ & \\
\hline \multirow[t]{3}{*}{$\begin{array}{l}\text { Diode, } D_{1} \\
\text { one-direction flow } \\
\text { prevents current } \\
\text { oscillation in the } \\
\text { circuit when ckt is } \\
\text { actuated }\end{array}$} & $\begin{array}{l}\text { Standby } \\
\text { component } \\
\text { for one- } \\
\text { direction } \\
\text { current flow }\end{array}$ & Short circuit & $\begin{array}{l}\text { Degraded unit, loss } \\
\text { of reverse blocking } \\
\text { ability }\end{array}$ & $\begin{array}{l}\text { Specify high } \\
\text { quality power diode }\end{array}$ & $\begin{array}{l}\text { Current in circuit could flow } \\
\text { in reverse direction, current } \\
\text { oscillation in circuit leading } \\
\text { to circuit damage. DM-1 } \\
\text { will not reset. }\end{array}$ & $\begin{array}{l}\text { Replace diode, repair } \\
\text { circuit. }\end{array}$ & $\begin{array}{l}\text { Fields (2012) gives } 48.3 \% \text { for } \\
\text { high power diode shorted failure } \\
\text { mode. Assume } S=3 \text { for cleanup } \\
\text { and diode replacement }\end{array}$ & $\begin{array}{l}8.5 \mathrm{E}-08 / \mathrm{h} \\
3000 \mathrm{~h} / \mathrm{y} \\
\mathrm{O}=1\end{array}$ & $\begin{array}{l}\text { Denson } \\
1996, \mathrm{p} 2- \\
12 \\
1.4 \mathrm{E}-07 / \mathrm{h} \\
1.25 \text { from } \\
\text { Table 2-4 }\end{array}$ & $3 \times 1=3$ & \\
\hline & & Open circuit & $\begin{array}{l}\text { Overheat leading } \\
\text { to wire melt }\end{array}$ & $\begin{array}{l}\text { Specify high } \\
\text { quality power diode }\end{array}$ & $\begin{array}{l}\text { Circuit will function to } \\
\text { actuate DM-1 valve, but will } \\
\text { not reset the thyristor }\end{array}$ & Replace diode & $\begin{array}{l}\text { Fields (2012) gives } 44.8 \% \text { for } \\
\text { opened failure mode. Assume } \\
\mathrm{S}=2 \text { for diode replacement }\end{array}$ & $\begin{array}{l}7.8 \mathrm{E}-08 / \mathrm{h} \\
3000 \mathrm{~h} / \mathrm{y} \\
\mathrm{O}=1\end{array}$ & $\begin{array}{l}\text { Denson } \\
1996, \mathrm{p} 2- \\
12 \\
1.4 \mathrm{E}-07 / \mathrm{h} \\
1.25 \text { from } \\
\text { Table 2-4 } \\
\end{array}$ & $2 \times 1=2$ & \\
\hline & & Drift & $\begin{array}{l}\text { Parameter change } \\
\text { by overstress, } \\
\text { reversed polarity }\end{array}$ & $\begin{array}{l}\text { Specify high } \\
\text { quality power diode }\end{array}$ & $\begin{array}{l}\text { Circuit will still function, } \\
\text { may take more than } 3 \text { hours } \\
\text { to reset system. }\end{array}$ & $\begin{array}{l}\text { Replace diode to restore } \\
\text { system operability }\end{array}$ & $\begin{array}{l}\text { Fields (2012) gives } 6.9 \% \text { for drift } \\
\text { failure mode. Assume } \mathrm{S}=2 \text { for } \\
\text { diode replacement }\end{array}$ & $\begin{array}{l}1.2 \mathrm{E}-08 / \mathrm{h} \\
3000 \mathrm{~h} / \mathrm{y} \\
\mathrm{O}=1\end{array}$ & $\begin{array}{l}\text { Denson } \\
1996, \mathrm{p} 2- \\
12 \\
1.4 \mathrm{E}-07 / \mathrm{h} \\
1.25 \text { from } \\
\text { Table 2-4 }\end{array}$ & $2 \times 1=2$ & \\
\hline
\end{tabular}


